\title{
A STRATEGIC COST-BENEFIT ANALYSIS OF ENERGY POLICIES: DETAILED PROJECTIONS
}

Harky Davitian, Richard J. Goettle IV, Paul J. Groncki, Edward A. Hudson, Peter Kleeman, and Joan Lukachinski

October 1979

NATIONAL CENTER FOR ANALYSIS OF ENERGY SYSTEMS DEPARTMENT OF ENERGY AND ENVIRONMENT

BROOKHAVEN NATIONAL LABORATORY UPTON, NEW YORK 11973 


\section{DISCLAIMER}

This report was prepared as an account of work sponsored by an agency of the United States Government. Neither the United States Government nor any agency Thereof, nor any of their employees, makes any warranty, express or implied, or assumes any legal liability or responsibility for the accuracy, completeness, or usefulness of any information, apparatus, product, or process disclosed, or represents that its use would not infringe privately owned rights. Reference herein to any specific commercial product, process, or service by trade name, trademark, manufacturer, or otherwise does not necessarily constitute or imply its endorsement, recommendation, or favoring by the United States Government or any agency thereof. The views and opinions of authors expressed herein do not necessarily state or reflect those of the United States Government or any agency thereof. 


\section{DISCLAIMER}

Portions of this document may be illegible in electronic image products. Images are produced from the best available original document. 


\title{
A STRATEGIC COST-BENEFIT ANALYSIS OF ENERGY POLICIES: DETAILED PROJECTIONS
}

\author{
Harry Davitian, Paul J. Groncki, Peter Kleeman, and Joan lukachinski \\ NATIONAL CENTER FOR ANALYSIS OF ENERGY SYSTEMS \\ BROOKHAVEN NATIONAL LABORATORY
}

RichaRd J. GOETTLE IV

EDWARD A. HUDSON

Dale W. Jorgenson Associates

October 1979

ECONOMIC ANALYSIS DIVISION

NATIONAL CENTER FOR ANALYSIS OF ENERGY SYSTEMS

- DEPARTMENT OF ENERGY AND ENVIRONMENT

BROOKHAVEN NATIONAL LABORATORY

ASSOCIATED UNIVERSITIES, INC.

PREPARED FOR THE OFFICE OF POLICY, PLANNING AND EVALUATION, CONSERVATION AND SOLAR APPLICATIONS, U.S. DEPARTMENT OF ENERGY

UNDER CONTRACT NO. DE-ACO2-76CH00016 


\section{DISCLAIMER}

This lunk was preparcl as all account ot work sponsorcd by an agency of the United States Government. Neither the United States Government nor any agcncy thereof, nor any of their employees, makes any warranty, express or implied, or assumes any legal liability or responsibility for the accuracy, completeness, or usefulness of any information, apparatus, product, or prosess disclosed, or represeuls ilat lts use would not Infringe privately owned rights. Reference herein to any specific commercial product, prosess, or corvicc by 1.1 ailrs name, tradcmark, ulanufacturer, or otherwise, does not necessarily constitute or imply its endorsement, recommendation, or favoring by the United States Government or any agency thereof. The views and opinions of authors expressed herein do not necessarily state or reflect those of the Unitcd States Government or any agency thereof.

Printed in the United States of America

Available from

National Technical Information Service

U.S. Department of Commerce

5285' Port Royal Road

Springtield, VA 22161

Price: Printed Copy $\$ 6.00$; Microfiche $\$ 3.00$ 


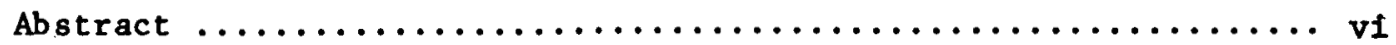

Acknowledgments $\ldots \ldots \ldots \ldots \ldots \ldots \ldots \ldots \ldots \ldots \ldots \ldots \ldots \ldots \ldots \ldots \ldots \ldots$

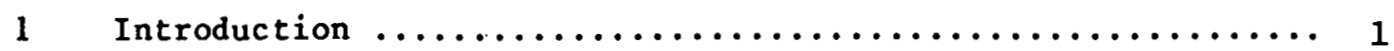

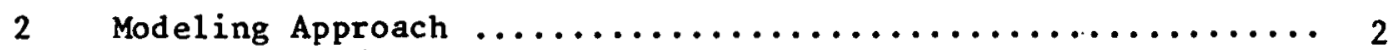

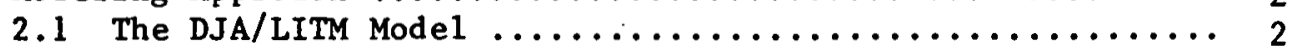

2.2 The BNL/TESOM Model $\ldots \ldots \ldots \ldots \ldots \ldots \ldots \ldots \ldots \ldots \ldots \ldots$

2.3 The BNL/Illinois I-O Model $\ldots \ldots \ldots \ldots \ldots \ldots \ldots \ldots \ldots, 6$

2.4 Model Integration $\ldots \ldots \ldots \ldots \ldots \ldots \ldots \ldots \ldots \ldots \ldots, \ldots \ldots$

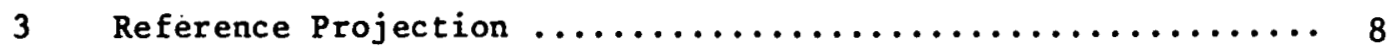

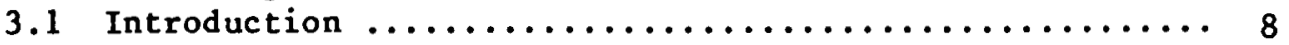

3.2 Assumptions and Methodology for the Reference

Projection........................... 8

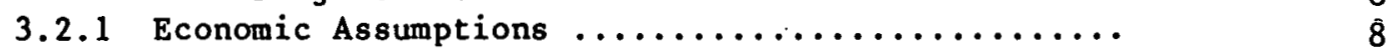

3.2.2 Energy System Assumptions $\ldots \ldots \ldots \ldots \ldots \ldots \ldots .8$

3.2.3 Incorporation of Assumptions in Model System .... 12

3.3 Reference Projection: Energy, Economy and

Environmental Interactions.................. 12

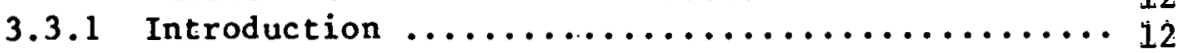

3.3.2 Economic Structure and Growth and Energy-

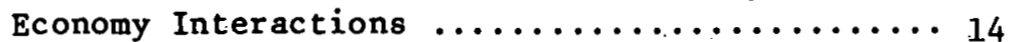

3.3.3 Energy System Development $\ldots \ldots \ldots \ldots \ldots \ldots \ldots \ldots 18$

3.3.4 Environmental Conditions .................... 31

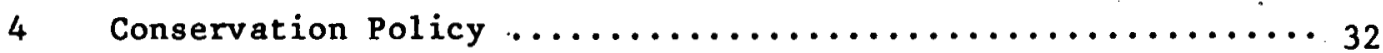

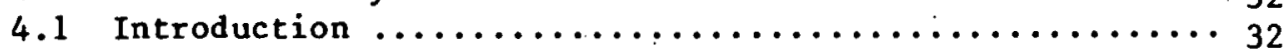

4.2 Assumptions and Methodology for the Conservation

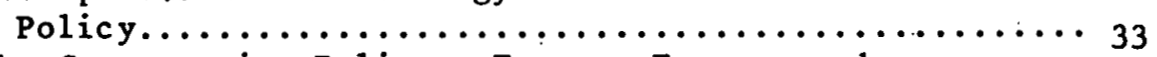

4.3 The Conservation Policy: Energy, Economy and

Environmental Interactions . . . . . . . . . . . . . 45

4.3 .1 Introduction ....................... 45

4.3 .2 Economic Structure and Growth............ 45

4.3 .3 Energy System Development............... 49

4.3.4 Environmental Conditions $\ldots \ldots \ldots \ldots \ldots \ldots \ldots \ldots 5$

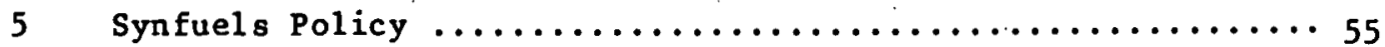

5.1 Introduction . . . . . . . . . . . . . . . . . . . 55

5.2 Assumptions and Methodologies for the Synfuels Policy... 55

5.3 The Synfuels Policy: Energy, Economy, and

Environmental Interections $\ldots \ldots \ldots \ldots \ldots \ldots \ldots \ldots \ldots$

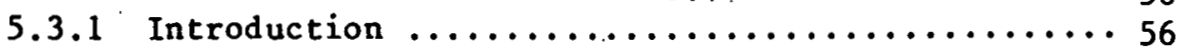

5.3 .2 Economic Structure and Growth $\ldots \ldots \ldots \ldots \ldots \ldots \ldots 6$

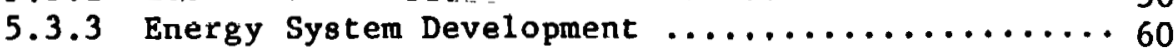

5.3 .4 Environmental Conditions $\ldots \ldots \ldots \ldots \ldots \ldots \ldots \ldots 67$ 
3.1 Energy Resource Prices: 1980-2025 ................... 9

3.2 Fuel Markups by Demand Category .................... 10

3.3 Domest1c 011 and Gas Supply Avallabillties .............. 10

3.4 Effictencies for End-Use Devices ................... 11

3.5 Annual Average Growth Rate of the Economy, Energy, and

Population: Reference Projection .................. 12

3.6 Energy and Economic Growth: Reference Case .............. 13

3.7 Labor, Output, and Productivity: Reference Case .......... 15

3.8 Economic Output and Expenditure: Reference Case .......... 15

3.9 Aggregate Final Demand Expenditure: Reference Case ........ 16

3.10 Aggregate Economic. Input Patterns; Share Coefficients for Aggregate Output: Reference Case ....... 17

3.11 The Level and Growth of Total Energy Service Demand: Reference Case ................................ 19

3.12 Energy Service Demands: Reference Case ................ 19

3.13 Energy Service Demands as Percentage of Total:

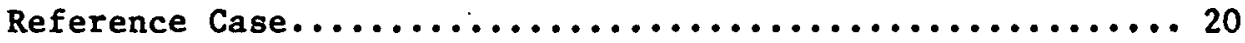

3.14 Delivered. Energy Quantitles by Aggregate Economic Sector: Reference Case .............................. 21

3.15 Delivered Energy Shares by Aggregate Economic Sector: Reference Case ............................... 22

3.16 Delivered Energy Quantities by Fuel Type: Reference Case ... 22

3.17 Delivered Energy Prices: Reference Case ............... 23

3.18 Electric Generation: Reference Case ................... 25

3.19 Electric Generation Fuel Shares: Reference Case .......... 25

3.20 Synthetic Fuel Production Levels: Reference Case ......... 26

3.21 Total Primary Energy Usage and Average Price: Reference Case ................................ 27

3.22 Primary Energy Usage: Reference Case ................. 28

3.23 Frimary Energy Usage as a Percentage of Total: Reference Case ............................... 29

3.24 Aggregate Energy Quantities and System Efficlencles: Reference Case ............................. 30

3.25 Environmental Indicators: Reference Projection .......... 32

4.1 Total Discounted Costs: Conservation Policy ............ 35

4.2 Subprograms With Uniform Distributions of Cost:

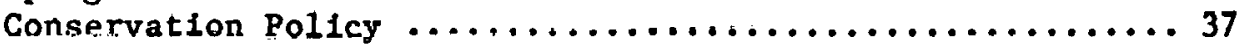

4.3 Subprograms With Constant Growth Distributions of Cost:

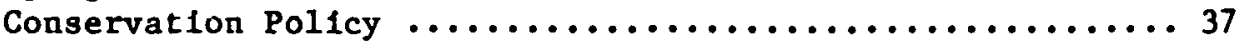

4.4 Subprograms With Trapezoldal Distributions of Cost:

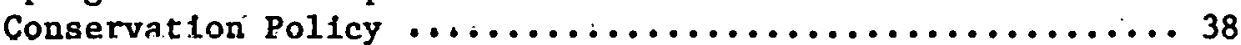

4.5 Sectors Used in Determining Investment/Labor Survices Allocations: Conservation Policy ........................ 39

4.6 Investment/Labor Services Allocation: Conservation Policy ........................... 40

4.7 Annual Costs and Energy Savings: Buildings/Community Systems: Conservation Policy ................... 41

4.8 Annual Costs and Energy Savings: Transportation: Conservation Policy ......................... 42 
Tables (Cont.)

\subsection{Annual Costs and Energy Savings: Industrial:}

Conservation Policy ..........................43

4.10 Annual Costs and Energy Savings: State and Local, Appropriate Technology: Conservation Policy ...........44 44

4.11 Annual Costs and Energy Savings: Conservation Policy ..... 45

4.12 Labor, Output, and Productivity: Conservation Case .......4 46

4.13 Economic Output and Expenditure: Conservation Case .......4 47.

4.14 Aggregate Final Demand Expenditures: Conservation Case ....48 48

4.15 Aggregate Economic Input Patterns; Share Coefficients for Aggregate Output: Conservation Case ............48

4.16 The Level and Growth of Total Energy Service Demand:

Conservation Case ......................... 49

4.17 Energy Service Demands: Conservation Case ............. 50

4.18 Delivered Energy Quantities by Aggregate Economic Sector:

Conservation Case .............................. 51

4.19 Delivered Energy Quantities by Fuel Type:

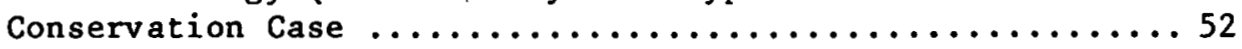

4.20 Delivered Energy Proces: Conservation Case ............ 53

4.21 Primary Energy Usage: Conservation Case ............... 54

4.22 Aggregate Energy Quantities and System Efficiencies:

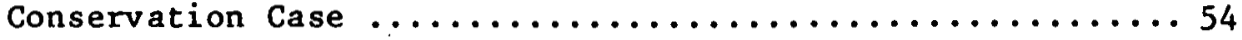

4.23, Environmental Indicators: Conservation Case ........... 55

5.1 Allocation of Incremental Synfuels Production for 1990:

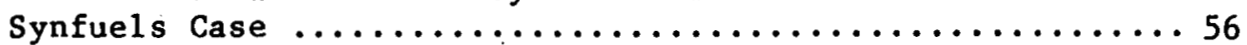

5.2 Labor, Output, and Productivity: Synfuels Case ......... 57

5.3. Economic Output and Expenditure: Synfuels Case .......... 58

5.4 Aggregate Final Demand Expenditures: Synfuels Case ....... 58

5.5 Aggregate Economic Input Patterns; Share Coefficients

for Aggregate Output: Synfuels Case ..............660

5.6 Energy Service Demands: Synfuels Case ................... 61

5.7 Delivered Energy Quantities by Aggregate Economic Sector:

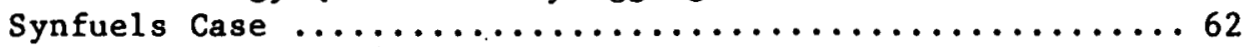

5.8 Delivered Energy Quantities by Fuel Type: Synfuels Case ...662

5.9 Delivered Energy Prices: Synfuels Case ..............6 63

5.10 Primary Energy Usage: Synfuels Case ................. 64

5.11 Tocal Primary Energy Usage and Average Price:

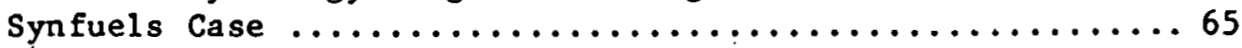

5.12 Aggregate Energy Quantities and System Efficiencies:

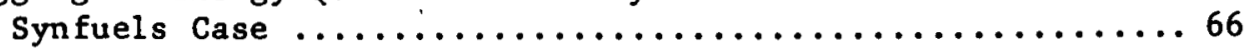

5.13 Environmental Indicators: Synfuels Policy ............. 67

Figures

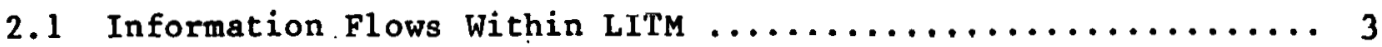

2.2 A Simplified Reference Energy System ............... 5

4.1 Types of Distribution Mechanisms for Determining

Annual Undiscounted Expenditures $\left(E_{i t}\right.$ ) from Total

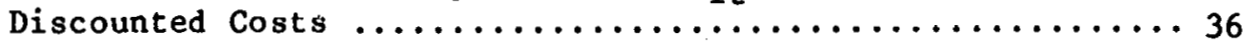




\section{ABSTRACT}

Current U.S. energy policy includes many programs directed toward restructuring the energy system in order to decrease U.S. dependence on foreign supplies and to increase our reliance on plentiful and environmentally benign energy forms. However, recent events have led to renewed concern over the direction of current energy policy. This study describes three possible energy strategies and analyzes each in terms of its economic, environmental, and national security benefits and costs. Each strategy is represented by a specific policy. In the first strategy no additional programs or policies are initiated beyond those currently in effect or announced. The second is directed toward reducing the growth in energy demand, i.e., energy conservation. The third promotes increased domestic supply through accelerated development of synthetic and unconventional fuels. The analysis focuses on the evaluation and comparison of these strategy alternatives with respect to their energy, economic, and environmental consequences. The results indicate that conservation can substantially reduce import dependence and slow the growth of energy demand, with only a small macroeconomic cost and with substantial environmental benefits; the synfuels policy reduces imports by a smaller amount, does not reduce the growth in energy demand, involves substantial environmental costs and slows the rate of economic growth. These relationships could be different if the energy savings per unit cost for conservation are less than anticipated, or if the costs of synthetic fuels can be significantly lowered. Given these uncertainties, both conservation and RD\&D support for synfuels should be included in future energy policy. However, between these policy alternatives, conservation appears to be the preferred strategy.

The results of this study are presented in three reports. The uverview presents a brief discussion of the motiviation for the study, the assumptions and methodologies employed, the results, and the policy implications. The Detalled Projections provides a more complete discussion of the input assumptions, methodology and rcsults of the three strategies analyzed. The Comparative Analysis discueseo the projections itative to each other, presents some sensitivity analyses that were performed, and provides a thorough discussion of the policy implications of the results.

\section{ACKNOWLEÖGMEN'SS}

The authors wish to acknowledge their indebtedness to Hwei-lin Hong, Duruthy Hatren, Eileen Klelman, and Scott Rogers for their computational and other assistance lin the preparation of this report. This report would not have been possible without the patience and typing skill of Margaret Gallitel11, Susan Walsh, Vanessa Crump and June Martino. 


\section{INTRODUCTION}

This is one of three reports on a study of energy policy alternatives. The first ${ }^{1}$ presents a brief discussion of the motivation for the study, the assumptions and methodologies employed, the results, and the policy implications. The report presented here provides a more complete discussion of the input assumptions, methodologies, and results of the three strategies analyzed. The third ${ }^{2}$ discusses the projections relative to each other, presents some sensitivity analyses that were performed, and provides a thorough discussion of the implications of the alternative policy strategies.

The recent disruption in world oil markets caused by the Iranian revolution, the rapid escalation in oil prices by OPEC, and the incident at Three Mile Island in Pennsylvania have again demonstrated the interdependencies among the nation's energy, economic, and environmental systems. These events have led to renewed concern over the nature and direction of U.S. energy policy and have provided an opportunity to define and clarify its direction. It is evident that this dependence of the U.S. on energy system developments can only be mitigated by a restructuring of the energy system so as to decrease our dependence on foreign supplies (which are subject to interruptions and price instability) and to increase our reliance on relatively more plentiful and environmentally benign domestic energy forms. This restructuring of the energy and economic systems can occur through several types of mechanisms:

- the development of options through research and development programs that expand the range of technical substitution possibilities for energy consumption;

- substitutions away from liquids toward other fuels where such adjustments are technically and economically feasible;

- reductions in the energy intensitites of production and consumption activities by substituting away from energy inputs;

- the restructuring of spending patterns away from energyintensive goods and services;

- the expansion of the domestic petroleum reserve base and domestic petroleum (and liquid fuel) output;

- the development of new energy supply alternatives that more fully utilize the domestic resource base.

Many of these changes will occur naturally as consumers and producers respond to the uncertain availability and expense of conventional fuels. However, government energy policy can speed this transition by providing incentives to encourage the more difficult or expensive adjustments.

Current U.S, energy policy contains many programs directed toward these ends. In fact, current policy is intended to provide a comprehensive program that reduces U.S. dependence on imports and increases use of plentiful domestic resoucres through both demand reduction and supply expansion. However, many problems have arisen in the design and implementation of energy policy and there is continued controversy over the components and direction of future policy. In formulating the direction of policy, it is important to examine the relative merits of each available strategy to ensure that the chosen policy yields the greatest com- 
bination of economic, environmental, and security benefits relative to the costs incurred. This report is directed to such an examination.

The range of future energy policy strategies may be characterized in terms of three alternative directions--no new policy, demand reduction, and supply expansion. Specific examples of each of these approaches are analyzed to determine their relative impacts. The first approach is to pursue a strategy of no additional policies or programs beyond those currently announced and in place (reference case), including the imposition of President Carter's import quota. The second is to direct policy toward reducing the growth in energy demand, i.e., energy conservation (conservation case). The third is to promote increased domestic supply primarily through an accelerated development of so-called synthetic and unconventional fuels (synfuels case). The analysis that follows is focused on the comparison and evaluation of these strategy alternatives, allowing for the energy, economic, and environmental consequences of each of these policy options.

\section{MODELING APPROACH}

Each of the component models in the integrated model framework is described in this section as well as the nethodology used in linking the models in an integrated model system.

\subsection{The DJA/LITM Model}

The DJA Long-term Interindustry Transactions Model (LITM) ${ }^{3}$ simulates the structure and growth of the U.S. economy and models the interaction between the economy and energy system. Production and spending throughout the economy are represented on a sectoral basis within a flexible interindustry framework. Substitutions are permitted among capital, energy, labor, and materials in the production of goods and services comprising the gross national product. LITM explicitly r.nnsiders ten production sectors, of which four are nonenergy and six define energy extraction and processing activities. These sectors are: agriculturp, nonfuel mining, and construction; manufacturing; transportation; services, trade and communications; coal mining; crude petroleum; petroleum refining; electric utilities; gas extraction; and gas utilities. Four categories of final demand for good and services are modeled in LITM: personal consumption expenditures, investment, government purchases, and exports. Ll'M also incorporates substitution or complementary relationships among inputs and adjustments in the pattern of final demand expenditures.

Economic activity patterns within the LITM framework are represented by econometrlc submodels tor consumption and for each producing sector. Thic givco a flexihle ani cousisteul rupresentation of cconomic behavior. The submodels provide a framework for the analysis of output price furmation and determine the relative prices characterizing the economy. These submodels also determine the minimum cost pattern of input purchases, given prevailing prices.

LITM is formulated ao a dynamic equilibrium model of Lile U.S. economy. For each of the commodities endogenous to the model, an algorithm of price formation based on the balance between demand and supply determines relative prices. The pattern of economic activity in each year is con- 


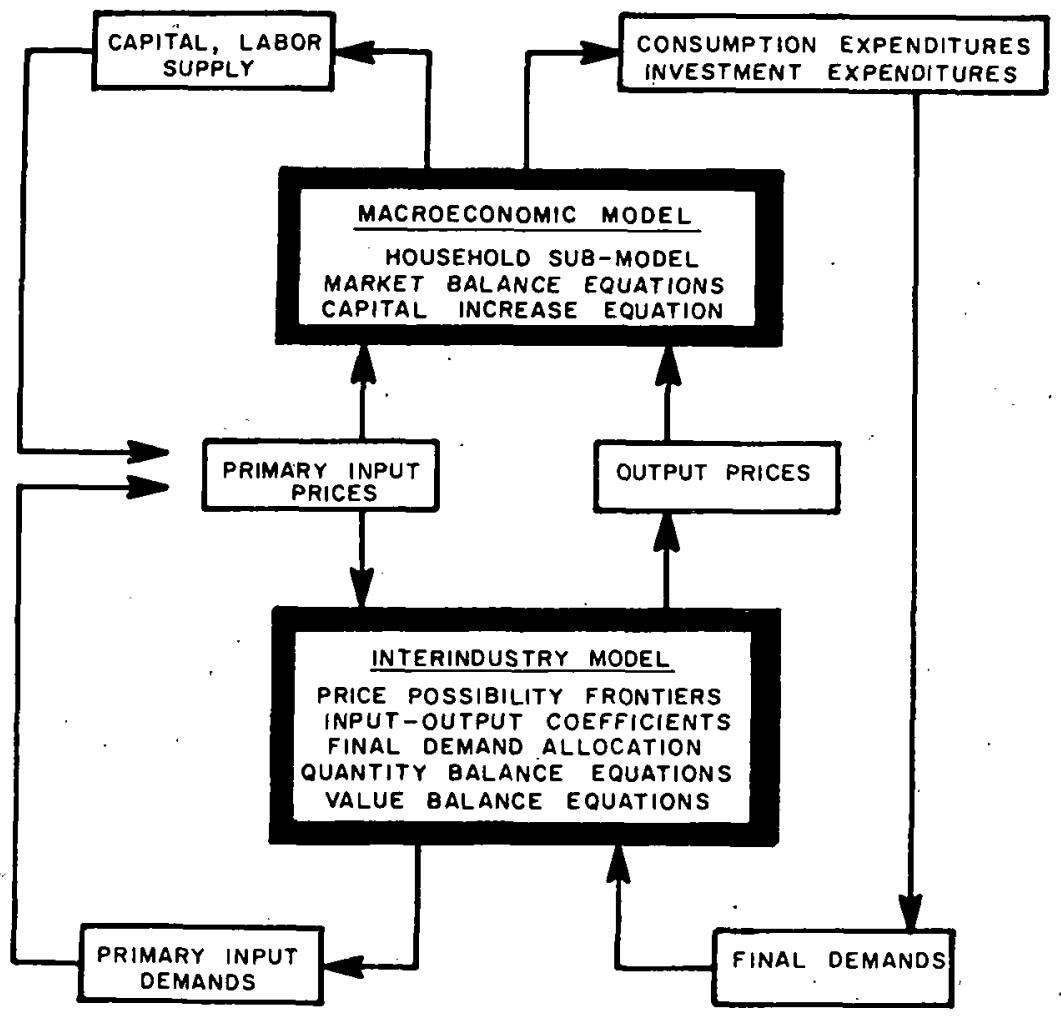

Figure 2.1. Information Flows Within LITM 
sistent with these relative prices. In addition, the LITM balances savings and investment to determine the rate of return on investment and the rate of growth of the capital stock. Economic growth is modeled as a sequence of one-period equilibria determining demand, supply, and relative prices for all commodities. Investment in each period determines the level of capital stock avallable in the following period. Figure 2.1 indicates the information flows within LITM.

\subsection{The BNL/TESOM Mode1}

The Brookhaven Time-stepped Energy System Optimization Model. (TESOM) $^{4}$ is a national energy system model for quantitative evaluation of energy technologies and policles within a systems framework. TESOM models fuel substitution and technological changes in the energy system as a function of resource avallability, technology choices, and their associated costs. The model is formulated as a linear program and is based on the Brookhaven Reference Energy System (RES). The RES provides an accounting system in physical units for energy flows from the extraction or importation of primary energy resources, though refining and conversion, transportation, distribution, and storage, to the final consumption of fuels and electricity by end-use technologies to meet a specific set of energy service demands. The comprehensive technological structure in TESOM relates energy flows to the relatively nonsubstitutable energy services such as space conditioning, motive power, and process heating. These energy services are defined so as to reflect the "useful work" nature of energy use. What is demanded by consumers (and industry) is gallons of hot water, square feet of floor space heated, and passenger miles. The fuels used to meet these requirements are considered to be derived demands. The RES framework reflects the feasible range of interfuel and technological substitutability. Figure 2.2 is a simplified RES which represents energy flows in the TESOM model.

The model optimally allocates energy resources and products at discrete points in time, and determines the mix of supply, conversion, and demand technologies according to least cost or other selected energy, environmental, or cconomic objectivce. Resource supply representations are specifled as elther supply curves, or fixed prices and avallabilities for each year.

Mathematically, the model is formulated as a sequence of expanding linear programming representations of the RES--reflecting all time periods considered. For a given time period, the solutions derived for earlier perlods along with assumptions regarding retirement and decline rates, average lifetimes, age-dependent conversion efficlencies, plant factors, O\&M costs, and the capital charges for stocks-in-place are incorporated into the time-sequenced formulation. Using a minimum cost or other quantifiable objective, the energy demands are satisfied for each successive time period in accordance with the supply expansions and technology penetrations attainable for the perlod, and the net avallabilities from the evolution of the energy system from previous periods.

The electric sector has a unique representation in the TESOM model. Required generating capacity is endogenously determined as a function of the exogenously defined electric demand types such as base and intermediate loads, off-peak, heating, and cooling demands. Required electric 


\begin{tabular}{|c|c|c|c|c|c|c|}
\hline $\begin{array}{l}\text { AESOURCE } \\
\text { EXTRACTION }\end{array}$ & $\begin{array}{c}\text { REFINING } \\
\text { AND } \\
\text { CONVERSION }\end{array}$ & TRANSPORT & CONVERSION & $\begin{array}{l}\text { TRANSMISSION } \\
\text { AND } \\
\text { OISTRIBUTION }\end{array}$ & $\begin{array}{l}\text { UTILIZING } \\
\text { DEVICE }\end{array}$ & END USE \\
\hline
\end{tabular}

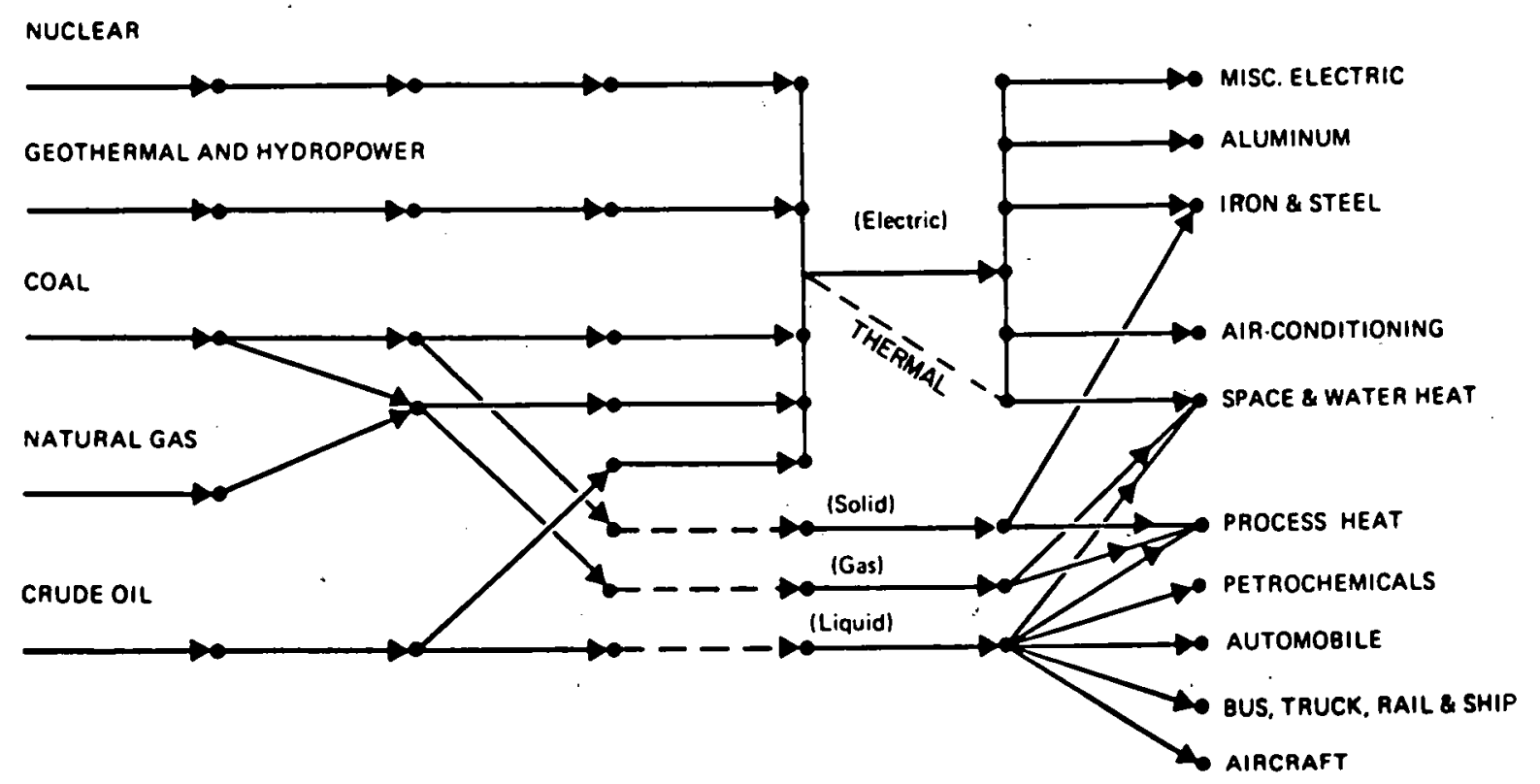

Figure 2.2. A Simplified Reference Energy System 
capacity is modeled as the maximum of the individual season-day peaks with allowances for transmissions and distribution losses and reserve margins. Load management considerations are introduced explicitly into the TESOM problem formulation since the load duration curve is determined, in part, from the exogenously specified set of energy service demands and their characteristics.

A mechanism for pricing and adjusting the avallabilities of vintage capital stocks, and a market penetration algorithm are incorporated in the TESOM model in order to smooth intertemporal transitions. All vintage capital stocks which are not beyond their economic 1ifetime impose an annualized capital charge on the system. Thus, fixed costs associated with previous investments are incurred whether or not it is optimal to operate an older technology. This eliminates "unrealistic" displacements of relatively Inefficient vintages.

The market penetration algorithm requires the "optimistic" penetration levels of each technology in each year as input. These user-specified bounds are then adjusted endogenously to account for the previous penetration and relative attractiveness of the technology. The penetration algorithm incorporates the marginal values, implementation rates, and lag times from previous periods as well as the technological and market characteristics for the current period into the determination of realistic bounds for each technology for each successive time period.

In addition to the energy and economy components of TESOM, an environmental impact model component is included. A set of constraints are included relating the levels of activity at any point in the energy system to environmental emissions levels. These constraints can be fixed to constraln the feasible set of energy options avallable, or used to determine the level of environmental emissions or impacts associated with each model solution for use in comparative analyses.

\subsection{The BNL/IIIInois I-O Model}

In constrast to conventional interindustry input-output models, the BNL/I11inols model is composed of 20 energy and 90 nonenergy sectors with the output of the energy sectors specifled in terms of physical Btu units instead of dollar values. 5 This permits direct linkage with the BNL energy process model, TESOM, and provides variable energy coefficients as determined by the solutions from TESOM. Outputs from the energy supply and conversion sectors are distributed to energy service sectors instead of directly to consuming sectors. The supply sectors convert and distribute raw fuels to sectors producing traditional energy forms such as electricity and refined petroleum products, but they allow for nontraditional patterns such as refined petroleum products from coal.

This structure results in the specification of transactions in terms of fuels and end uses. The energy product sectors define elght nonsubstitutable end-uoc demands for uutigy: motive power, petrochemical feedstock, coke, process heat, water heat, space heat, air conditioning, and electric power.

The intergration of TESOM and LITM occurs through the I-0 model. The I-0 model, when solved, ylelds the detalled output requirements of the economy. Aggregate nonenergy final demands from T.ITM serve as control totals for the nonenergy final demands in the input-output model. 
The total energy demands are provided by the $I-O$ in the form of energy services spectfied in physical units. In turn, the technological coefficlents representing the energy supply to energy product conversions are derived from the TESOM solution. The interindustry structure of the BNL input-output transactions matrix provides a significant degree of disaggregation and permits detailed sectoral analysis within the national economy.

\subsection{Mode1 Integration}

The TESOM, I-0, and LITM models are coupled so that in each year there is consistency between the energy and economic information obtained from each model. ${ }^{6}, 7$ This coupling is achieved through an iterative process in which the principal points of interaction are:

- the economic activities of each sector and the aggregate energy inputs to the producing sectors, household sectors, and other final demands;

- the relationship between the aggregate energy inputs to the producing and consuming sectors and the levels of the nonsubstitutable, functional energy services;

- the details of energy process, technology production functions, quantfties, imports, and the levels of new and conventional energy technologies;

- the relationship among the energy sector details, aggregate energy and nonenergy input substitutions, product substitutions and compositional changes in final demand, and the growth of the economy from both demand and supply viewpoints.

The models interface at the point of energy demand, with LITM linkIng aggregate energy demand to the economy and TESOM linking primary resources to energy demand. The linked system extends the coverage and applicability of each model and provides a framework for the consistent analysts of energy technologles, energy supply and energy policies.

The solution values for energy prices, technology production functions, quantities, imports, and the levels of new energy technologies from TESOM are passed to the LITM model which generates estimates of the level and composition of production and spending throughout the economy. Economic sector outputs and the energy input per unit of output are transformed into a restructured set of demands for energy services in physical unfts. This mapping occurs through a "reduced form" version of the BNL/I11inols Input-Output Model. Mathematically, these adjustments to the level and structure of energy service demands are determined by accounting for changes in the level and structure of economic activity and in energy requirements per dollar of output for each sector. The resultant vector of energy service demands reflects changes in energy prices, the level and composition of economy activity, energy and nonenergy input substitutions in production, and energy system efficiencies. These energy demands are used in TESOM to produce a new optimal configuration of the energy system: This interative procedure continues until consistency between the energy and economic systems in the integrated model system is obtained. 


\section{REFERENCE PROJECTION}

\subsection{Introduction}

In this section, the numerical and interpretive results for the BNL/ DJA reference projection are presented. The subsequent discussions provide overviews of long-run energy and economic growth, the structural aspects of energy-economy interactions, the details of the evolution of the energy systems, and the environmental implications of this evolution.

\subsection{Assumptions and Methodology}

3.2.1 Economic Assumptions. The LITM economic model requires input assumptions on future population, government expenditure and revenue policies, and the unemployment rate. The Census Bureau's Series II population projections (fertility rate of 2.1 ) were used to derive figures on the future population. Labor force participation rates are endogenous to the model and are not specified as assumptions. The unemployment rate was assumed to follow a cyclical pattern from 6.0 percent in 1978 to 5.6 percent in 1985, and then to decline slightly over the rest of the forecast period. Government purchases increase slightly relative to the rest of the economy (from 19.4 percent of real GNP in 1980 to 19.9 percent by 2000) reflecting current trends of government programs including new developments in the health, services, energy, and defense areas. Government transfers and tax revenues rise approximately in line with the economy as a whole. Most of the productivity effects in the model are endoganous and are not specified as assumptions, while the energy supply productivity information is obtained from the TESOM model.

3.2.2 Energy system assumptions. The reference case projection incorporates assumptions regarding the prices and availabilities of energy resources; capital and generating costs for electricity generation, synthetic fuel production, and end-use devices; market penetration rates for new energy technologies; and changes in efficiencies of fuel conversion over time. The reference case presents a projection of U.S. energy consumption and production over the 1980 to 2025 time horizon. Policy initiatives or actions that are currently either in.place via legislation or announced and under the control of the Executive Branch are included. The reference case incorporates the oil import quotas announced by President Carter in his energy speech of July 15, 1979. The quotas require that the future annual levels of oil imports never exceed the $19 \%$ level, and that they are reduced to one-half the 1977 level by the year 1990 .

Energy pricing assumptions include the phased decontrol of domestic oil prices by the year 1981. No corresponding windfall profits tax is included, as such proposed legislation has not been enacted and is not under Execurive Branch control. The NEP II High $P_{L}$ ice tiajectoly finr world oil prices is assumed for the reference case. ${ }^{8}$ In constant 1978 dollars per barrel, the world oil price rises from $\$ 20$ in 1980 to $\$ 38$ in 2000 , and to $\$ 64$ by the year 2025. (These correspond to prices of 2.28 , 4.33, and 7.29 in 1972 dollars per million Btu.) Shale oil prices are assumed $l u$ be 25 percent above the world oil price in all ycaro. 
The price of natural gas, in constant 1972 dollars, is estimated to rise from $\$ 0.78$ per million Btu in 1980 to $\$ 4.33$ by the year 2000 . There is a 9.0 percent. per annum rate of growth during the period prior to 2000 , as the gas price is assumed to: be deregulated by 1985 and increase rapidly until it approaches the crude oil price. After 2000 , the natural gas price follows a trend similar to that given for crude oil, and rises at an average rate of 2.1 percent per year. The prices for natural gas in 1980 and 1985 are obtained from a U.S. Department of Energy report entitled, An Evaluation of Natural Gas Pricing Proposals. ${ }^{9}$ The gas prices for 1990 and beyond are projected such that they are competitive with refined petroleum utilizing devices in the generation of residential, conmerical, and industrial heating services.

The supply price of coal was defined as a price for steam coal at minemouth. Metallurgical coal prices were obtained by applying additional markups to the steam coal price to reflect quality differences in coal type. The price of coal at the minemouth was assumed to grow at an average annual rate of 3.6 percent in the pre-2000 period, rising from $\$ 0.50$ per million Btu in 1980 to $\$ 1.00$ in the year 2000. The coal price.was projected to remain relatively constant after 2000 , rising at an average rate of 0.2 percent per year to $\$ 1.05$ in 2025 . These steam coal prices are assumed to be quantity-weighted averages of the various coal types.

In addition to the coal, oil, and gas pricing assumptions, the reference case incorporates resource prices for wood, biomass, solid waste, and uranium. Supply prices for all primary energy resources are presented in Table 3.1 for each year.

\begin{tabular}{|c|c|c|c|c|c|}
\hline & \multicolumn{4}{|c|}{$\begin{array}{l}\text { Table 3.1 } \\
\text { Energy Resource Prices: 1980-2025 } \\
\text { (1972 Dollars/Million Btu) }\end{array}$} & \multirow[b]{2}{*}{2025} \\
\hline & 1980 & 1990 & 2000 & 2010 & \\
\hline Domestic oil & 2.28 & 3.14 & 4.33 & 5.33 & 7.29 \\
\hline Imported oil & 2.28 & 3.14 & 4.33 & 5.33 & 7.29 \\
\hline Shale oil & 2.85 & 3.92 & 5.42 & 6.67 & 9.11 \\
\hline Domestic gas & 0.78 & 3,17 & 4.33 & 5.31 & 7.27 \\
\hline Imported gas & 2.05 & 3.17 & 4.33 & 5.31 & 7.27 \\
\hline Unconventional gas & 2.85 & 3.96 & 5.42 & 6.67 & 9.11 \\
\hline Coal & 0.50 & 0.72 & 1.00 & 1.02 & 1.05 \\
\hline Uranium & 0.35 & 0.35 & 0.39 & 0.44 & 0.52 \\
\hline Wood & 1.20 & $1.33^{\circ}$ & 1.47 & 1.55 & 1.68 \\
\hline Solid waste & 0.44 & 0.90 & 1.57 & 2.24 & 3.54 \\
\hline Biomass & 0.35 & 0.75 & 1.49 & 2.16 & 3.46 \\
\hline
\end{tabular}


Markups of fuels by end-use demand category are shown for each fuel type in Table 3.2. With the exception of the metallurgical coal price differential built into the coal to iron and steel category, markups are assumed to be constant over time.

\begin{tabular}{|c|c|c|c|c|c|c|c|}
\hline & Fue 1 & $\begin{array}{r}\text { Mark } \\
\quad(1\end{array}$ & $\begin{array}{l}\text { Table } 3 \\
\text { sps by Der } \\
372 \$ / 10^{6}\end{array}$ & $\begin{array}{l}.2 \\
\text { Btu }\end{array}$ & Category & . & \\
\hline & 011 & Gas & Coal & Wood & $\begin{array}{l}\text { Lo-Btu } \\
\text { coal gas }\end{array}$ & Methanol & Hydrogen \\
\hline Electrlc utilities & 0.63 & 0.39 & 0.25 & 0.25 & - & - & 2.24 \\
\hline $\begin{array}{r}\text { Resldential/ } \\
\text { commercial } \\
\text { Space heat } \\
\text { Water heat }\end{array}$ & $\begin{array}{l}0.63 \\
0.63\end{array}$ & $\begin{array}{l}0.70 \\
0.71\end{array}$ & - & $\begin{array}{c}. \\
0.57 \\
0.57\end{array}$ & - & - & $\begin{array}{l}2.24 \\
2.24\end{array}$ \\
\hline $\begin{array}{l}\text { Industry } \\
\text { Process heat } \\
\text { Petrochemicals } \\
\text { Iron \& steel }\end{array}$ & $\begin{array}{l}0.30 \\
0.30 \\
0.33 \\
-\end{array}$ & $\begin{array}{l}0.39 \\
0.39 \\
0.39 \\
-\end{array}$ & $\begin{array}{l}0.36 \\
0.36 \\
0.36 \\
0.53-1.10\end{array}$ & $\begin{array}{l}0.57 \\
0.57 \\
0.57 \\
-\end{array}$ & $\begin{array}{l}0.39 \\
0.39 \\
0.39 \\
-\end{array}$ & $\begin{array}{l}- \\
\dot{-} \\
-\end{array}$ & $\begin{array}{l}2.24 \\
2.24 \\
- \\
-\end{array}$ \\
\hline $\begin{array}{l}\text { Transportation } \\
\text { Afr transport } \\
\text { Truck \& bus } \\
\text { Ship } \\
\text { Automobile }\end{array}$ & $\begin{array}{l}1.13 \\
0.57 \\
1.13 \\
1.44\end{array}$ & $\begin{array}{l}- \\
- \\
-\end{array}$ & $\begin{array}{l}- \\
- \\
-\end{array}$ & $\begin{array}{l}- \\
- \\
-\end{array}$ & $\begin{array}{l}- \\
- \\
-\end{array}$ & $\begin{array}{l}- \\
2.75 \\
- \\
2.75\end{array}$ & $\begin{array}{l}- \\
1.68 \\
- \\
1.68\end{array}$ \\
\hline
\end{tabular}

Domestic ofl and gas production possibilities are based upon U.S. Geological Survey mean geology estimates. 10 Yearly estimates of production are determined by fitting a Hubbert curve to historical data (from 1947 to the present and estimates to 1985) and determining parameters for the curve that align the 1980 value with actual production estimates, and yield the total cumulative production levels given by the USGS Mean Geology estimates. Domestic ofl and gas supply availabilities are given In Table 3.3 for each year.

Table 3.3

Domestic 011 and Gas Supply Availabilities (quadrililion Btu)

\begin{tabular}{rrc}
\hline & Domestic oll & Domestic gas \\
\hline 1980 & 21.0 & 18.8 \\
1990 & 19.3 & 17.6 \\
2000 & 16.1 & 15.0 \\
2010 & 12.6 & 12.0 \\
2025 & 7.9 & 7.7 \\
\hline
\end{tabular}


Shale oil production is constrained in all time periods. Shale oil is assumed to enter the energy system at a level of 0.1 quads in 1985, grow to 0.8 quads by 2000 and provide 2.0 quats of primary energy input by the year 2025 .

Coal production is not constrained and the projected levels of coal consumption are endogenously determined within the TESOM model.

Uranium resource levels required for inputs to nuclear electricity generation are constrained in accordance with the assumptions made regarding nuclear expansion. Nuclear electric generating capacity is assumed to reach 155 gigwatts during the 1985 to 1990 period, then increases to 215 gigawatts by the year 2000. The growth rate of nuclear expansion in the post-2000 period is limited so as not to exceed growth over the 1990-2000 period, and increases at an average annual rate of 2.4 percent as contrasted with a pre-2000 rate of 6.5 percent.

Conversion efficiencies for new end-use devices are presented in Table 3.4. In addition to the increase in efficiencies projected for new devices, TESOM accounts for deterioration of the efficiencies of existing capital equipment. Therefore, the average efficiency of all vintages to a particular device will be below those values given in Table 3.4 for new devices.

Table 3.4

Efficiencies for End-Use Devices

\begin{tabular}{|c|c|c|c|c|c|}
\hline & 1980 & 1990 & 2000 & 2010 & 2025 \\
\hline \multicolumn{6}{|l|}{0 oil \& methanol } \\
\hline Space heat & 0.50 & 0.59 & 0.66 & 0.71 & 0.75 \\
\hline Water heat & 0.63 & 0.63 & 0.64 & 0.64 & 0.65 \\
\hline Process heat & 0.70 & 0.73 & 0.75 & 0.77 & 0.78 \\
\hline Truck \& bus & 0.21 & 0.24 & 0.25 & 0.25 & 0.26 \\
\hline Ship & 0.21 & 0.24 & 0.25 & 0.25 & 0.26 \\
\hline Air transport & 0.22 & 0.27 & 0.30 & 0.31 & 0.32 \\
\hline Auto & 0.24 & 0.32 & 0.38 & 0.42 & 0.45 \\
\hline Petrochemicals & 1.00 & 1.00 & 1.00 & 1.00 & 1.00 \\
\hline \multicolumn{6}{|l|}{ Gas \& low-Btu gas } \\
\hline Space heat & 0.54 & 0.63 & 0.70 & 0.75 & 0.79 \\
\hline Water heat & 0.65 & 0.65 & 0.66 & 0.66 & 0.67 \\
\hline Process heat & 0,65 & 0.68 & 0.70 & 0.72 & 0.73 \\
\hline Air conditioning & 1.80 & 1.80 & 1.80 & 1.80 & 1.80 \\
\hline Petrochemicals & 1.00 & 1.00 & 1.00 & 1.00 & 1.00 \\
\hline \multicolumn{6}{|l|}{ Coal } \\
\hline Process heat & 0.70 & 0.75 & 0.79 & 0.81 & 0.84 \\
\hline Petrochemicals & 1.00 & 1.00 & 1.00 & 1.00 & 1.00 \\
\hline $\begin{array}{l}\text { Iron \& steel } \\
\text { Wood }\end{array}$ & 0.24 & 0.25 & 0.26 & 0.26 & 0.27 \\
\hline Space heat & 0.60 & 0.64 & 0.67 & 0.69 & 0.72 \\
\hline Water heat & 0.62 & 0.66 & 0.69 & 0.72 & 0.75 \\
\hline $\begin{array}{l}\text { Process heat } \\
\text { Electric }\end{array}$ & 0.70 & 0.75 & 0.79 & 0.81 & 0.84 \\
\hline Air conditioning & 3.0 & 3.3 & 3.5 & 3.6 & 3.8 \\
\hline $\begin{array}{l}\text { Heat pump- } \\
\text { space heat }\end{array}$ & 2.0 & 2.0 & 2.0 & 2.0 & 2.0 \\
\hline
\end{tabular}


3.2.3 Incorporation of Assumptions in Model System. The sets of economic and energy assumptions discussed above were incorporated into the BNL/TESOM and DJA/LITM models. 7 The TESOM model solves for the least cost set of resources required to meet the set of energy service demands within the constraints specified for the reference case. The DJA model determines the level and composition of economic activity and inputs to production and consuming sectors consistent with the set of energy prices and availabilities, and energy technology production functions incorporated in the TESOM model solution. The models are solved iteratively, with the DJA solution used to adjust the level and structure of energy service demands, until an equilibrium set of energy and economic information is generated from the integrated model system.

\subsection{Reference Case: Energy, Economy, and Environmental Interactions}

3.1 Introduction. The U.S. economy and 1ts use of energy are projected to show continued growth through the first quarter of the next century. However, the growth rates are expected to decline appreciably from past trends. The reference projection can be placed in perspective by considering it in the context of trendy over the past thirty years. Table 3.5 shows the annual average growth rates of real GNP, primary energy consumption, and the population for selected historical and projected periods.

\begin{tabular}{|c|c|c|c|}
\hline & of the Econo & $\begin{array}{l}5 \\
\text { owth Rates } \\
\text { and Population: } \\
\text { ection } \\
\text { Year) }\end{array}$ & \\
\hline & Real GNP & Primary energy & Population \\
\hline $\begin{array}{r}\text { Historical: } \\
1950-1960 \\
1960-1970 \\
1970-1978\end{array}$ & $\begin{array}{l}3.28 \\
3.85 \\
3.22\end{array}$ & $\begin{array}{l}2.76 \\
4.19 \\
1.93\end{array}$ & $\begin{array}{l}1.71 \\
1.26 \\
0.80\end{array}$ \\
\hline $\begin{array}{c}\text { Pro.jected: } \\
1980-1990 \\
1990-2000 \\
2000-2010 \\
2010-2025\end{array}$ & $\begin{array}{l}2.98 \\
2.65 \\
2.38 \\
2.11\end{array}$ & $\begin{array}{l}1.66 \\
1.23 \\
1.79 \\
1.29\end{array}$ & $\begin{array}{l}0.92 \\
0.67 \\
0.56 \\
0.48\end{array}$ \\
\hline
\end{tabular}

The rate of population growli under the Scrice II projection shows a steady decline toward, although not reaching, a zero rate. Economic growth continues, although at steadily declining rates. Historical patterns of economlc growth in excess of 3.0 percent per annum are not experienced in the future as real GNP growth averages 2.8 percent annually to 2000 and only 2.2 percent thereafter. This slowing in the rate of economic growth reflects the slowing of both labor force expansion and 
productivity advance. One reason for the lower rate of productivity growth 19 the continuing escalation of real energy prices.

As the demand for energy is a derived demand, the future growth pattern of primary input reflects both the slower growth of population and aggregate economic activity and the increases in real energy prices stipulated for this projection. The seemingly anomalous pattern of energy growth in the sixties, resulting, in part, from the influences of population dynamics and the Vletnam War on the rate and structure of economic expansion, is projected not to recur. Rather, under the continuing influence of higher real energy prices, the trend in primary energy growth departs from earlier patterns and continues on the path begun in the seventies.

A common measure of the aggregate efficlency of energy use in the economy is given by the ratio of primary energy consumption to the real value of total final output. With some fluctuations in the short run, the long-run historical trend in this measure has been downward in spite of the fact that energy prices, in real terms, were declining. Under conditions of rising energy prices, there is the expectation of increasing technical efficiency of energy conversion and end use, technical progress in the economy as a whole, and shifts in expenditure and production patterns away from energy, energy-intensive, and energy-assoclated goods and services. Thus, the energy-GNP ratio is projected to continue its downwind movement.

The energy-GNP ratio and its components are shown in Table 3.6. The growth in primary energy consumption is less than that of final output over the entire projection horizon. The pattern of steepest descent occurs during the period 1980-2000 as the average real price of delivered

Table 3.6

Energy and Economic Growth: Reference Case

\begin{tabular}{cccc}
\hline Year & $\begin{array}{c}\text { Real GNP } \\
\text { (billions of } \\
\text { 1972 dollars) }\end{array}$ & $\begin{array}{c}\text { Primary energy } \\
\text { (quadrilition Btu) }\end{array}$ & $\begin{array}{c}\text { Energy-GNP ratio } \\
\text { (thousand Btu per } \\
1972 \text { dollar) }\end{array}$ \\
\hline $\begin{array}{c}\text { Historical: } \\
1972\end{array}$ & 1172.1 & & \\
1971. & 1217.8 & 71.6 & 61.1 \\
1976 & 1273.0 & 72.6 & 59.6 \\
1978 & 1399.2 & 74.4 & 58.4 \\
Projected : & & 78.2 & 55.9 \\
1980 & 1417.1 & & 58.0 \\
1990 & 1901.3 & 82.2 & 51.0 \\
2000 & 2469.3 & 96.9 & 44.3 \\
2010 & 3125.2 & 109.5 & 41.9 \\
2025 & 4277.1 & 130.8 & 37.1 \\
\hline
\end{tabular}

energy increases steadily. Specifically, there is a 23.6 percent decline in the ratio over this interval. In the early years to 1990, energy prices increase most rapidly as natural gas prices are deregulated 
gradually and decontrol permits domestic ofl prices to rise to match the Increasing world oil price. Reflecting the phased substitution of energy from relatively expensive sources, the energy-GNP ratio exhibits a lagged response to these price changes. of the change during 1980-2000, the rate of reduction in the ratlo is greatest during the last decade of the century.

After 2000, the trend in the average delivered energy price is significantly different. To 2010, increases in this price follow the more moderate pattern begun during the late 1990's. The real price actually declines after 2010 because, increasingly, relatively less expensive fuels are substituted in the delivered energy mix. The moderation of energy price increases, the continued substitution of electricity and synthetic fuels (with the energy implications of their conversion losses), and the influence of other long-run, energy-economy interactions (population and labor force dynamics) contribute to the slowing of the rate of decline of the energy-GNP ratio. There is only a 16.3 percent improvement in the ratio over the first quarter of the next century. Thus, while energy growth is still lower than the growth in total final output, the difference is somewhat less than for the pre-2000 period. However, the long-run pattern of the energy-GNP ratio for the reference projection suggests a continuous accommodation of more costly and less readily avallable energy supplies.

3.3.2 Economic Structure and Growth and Energy-Economy Interactions. U.S. economic growth is sustained at a positive, though decilning, rate through 2025. Growth at around 2.8 percent annually through 2000 declines to a 2.2 percent annual rate for the first quarter of the next century. This ensures a continuing increase in material living standards as real GNP per capita rises from the 1978 level of $\$ 6,339$ (1972 dollars) to $\$ 9,483$ in 2000 and $\$ 14,464$ by the year 2025 .

Th1s growth can be expressed as the sum of the rate of growth in employment and the rate of increase of gross labor productivity, defined as real GNP per person employed. Table 3.7 presents the principal labor, final output, and productivity varlables. The level of employment rises hy 26.7 million persons between 1980 and 2000 and by an additional 22.1 million workers thorugh the year 2025. However, becuuse of ehanges in the demographic structure of the population, labor force expansion slows continuously over the entire projection horizon.

Advances in gross labor productivity account for the portion of real growth not due to employment increases. Improvements in gross labor productivity include the ettects of Increased labor and capital efficiency, and the capital-1abor ratio. Also included are the effects of changes in the sectoral mix of production. Over the forecast periud, the ratc of productivity advance is between 1.5 and 1.7 percent annually. Although this is beliow the historical rate of advance, increased productivity still concributus materfally to overall. esnnomic growth. Unt11 1990, productivity and employment increases provide about equal increments to real GNP growth. However, after this time, productivity improvements account for an increasing fraction of real growth. By 2025, over 70 percent of economic growth is attributable to productivity advance.

The Increased quantity of production consistent with this growth pattern permits a continuing rise in the volume of expenditure that the 
Table 3.7

Labor, Output, and Productivity:

Reference Case

\begin{tabular}{|c|c|c|c|c|c|}
\hline & 1980 & 1990 & 2000 & 2010 & 2025 \\
\hline Population, million & 222.2 & 243.5 & 260.4 & 275.3 & 295.7 \\
\hline Employment, million & 97.8 & 112.6 & 124.5 & 134.0 & 146.6 \\
\hline Unemployment rate, percent & 5.8 & 5.0 & 4.7 & 4.3 & 4.0 \\
\hline Real GNP, $10^{9} \$(1972)$ & 1417.1 & 1901.3 & 2469.3 & 3125.2 & 4277.1 \\
\hline Real GNP per capita, & & & & & \\
\hline $10^{3} \$(1972)$ & 6.378 & 7.808 & 9.483 & 11.352 & 14.464 \\
\hline Gross labor productivity & & & & & \\
\hline $10^{3} \$(1972)$ per worker & 14.490 & 16.885 & 19.834 & 23.322 & 29.175 \\
\hline \multicolumn{6}{|l|}{ Average annual growth rates } \\
\hline Population & & 0.92 & 0.67 & 0.56 & 0.48 \\
\hline Employment & & 1.42 & 1.01 & 0.74 & 0.60 \\
\hline Real GNP & & 2.98 & 2.65 & 2.38 & 2.11 \\
\hline Real GNP per capita & & 2.04 & 1.96 & 1.82 & 1.63 \\
\hline Gross labor productivity & & 1.54 & 1.62 & 1.63 & 1.50 \\
\hline
\end{tabular}

economy can support. In Table 3.8, these expenditures are divided into purchases by the household, business, government, and foreign sectors. Consumers, investors, and governments share the increased expenditure;

Table 3.8

Economic Output and Expenditure: Reference Case

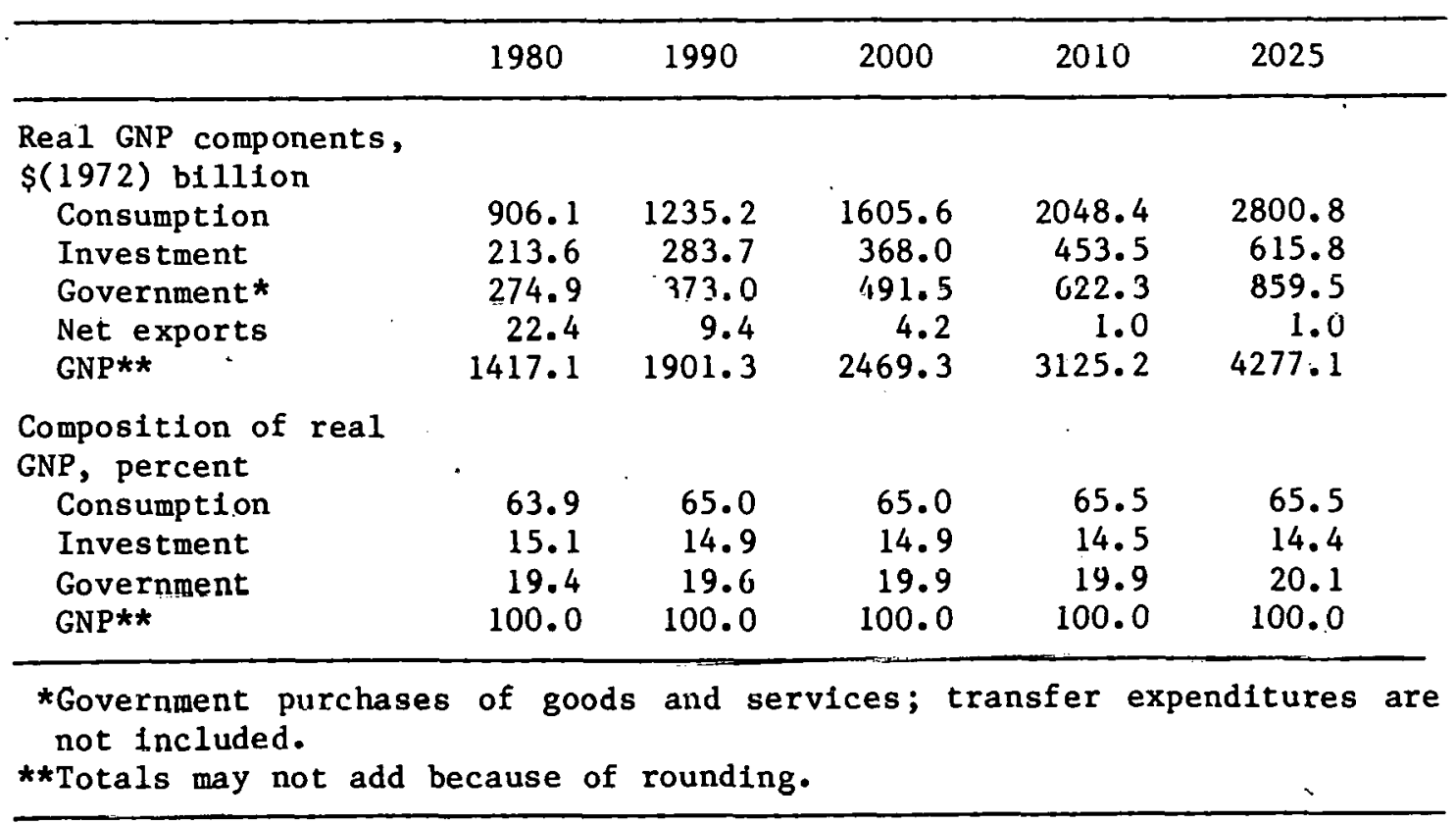


only the foreign sector declines in relative importance. Consumption remains the dominant use of final output and increases slightly its share of total real spending. Real per capital consumption more than doubles over the projection horizon, increasing in 1972 dollars from 4,078 in 1980 to 9,472 by the year 2025. The investment share of total spending remains approximately unchanged between 14.0 and 15.0 percent of real GNP. These projections suggest no significant changes in aggregate patterns of purchases by sector.

There is, however, a more significant restructuring of the economy in terms of the sectoral mix of these purchases. The information in Table 3.9 shows the projected changes in the output pattern of real final demand. The year 1990 is pivotal for the reference projection. To 1990, recent historical trends in the output shares of final demand persist. Manufacturing continues to decline in relative importance and there are significant increases in the expenditure shares of agriculture, constructinn, trade and services, and energy. The substantial increase in the relative importance of trade and services accentuates the trend that has been apparent in the past, in part, because higher energy prices lead to relatively more expensive energy-intensive, and energy-associated products and outputs, and purchasers respond to these price increases by redirecting expenditures toward nonenergy-intensive goods and services. Thus, the role of trade and services within final demand spending increases, whereas that of manufacturing diminishes. The increased share

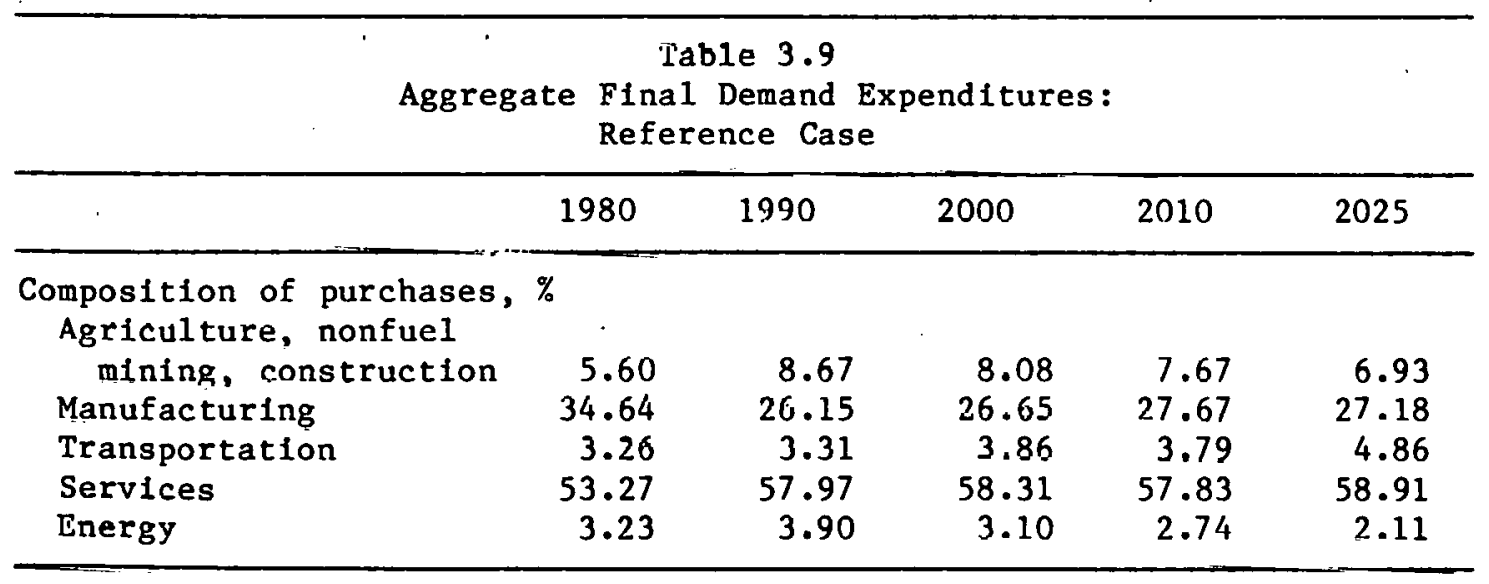

of energy to 1990 results from the combined influences of real energy price increases, relatively strong economic growth, and the insbility to adjust instantancously energy-consuming capital stocks.

After 1990, there are major reversals in the trends of final demand chares. Manufacturing's share stabilizes at around 27 percent and the share of agriculture, nonfuel mining, and construction declines reflecting, in part, slower population growth. Trade and services continue to 
absorb the largest fraction of increased spending, though its share also stabilizes. Transportation and communications become relatively more important as locational patterns exert more influence. Finally, as constraints on capltal stock turnover become less restrictive and desired substitutions are realized, i.e., demand adjustments to higher prices are more complete, energy's share of total spending declines steadily.

Further effects attributable to these demand substitutions concern labor and capital productivities. For example, the production of services is characterized by relatively higher labor and capltal contents. Therefore, the shift of spending toward these sectors leads to increases, ceteris paribus, in the quantities of capital and labor required, on average, per unit of output. But these are equivalent to reductions in the quantity of output obtained, on average, per unit of capital and labor input. Over time, as the expenditure adjustments occur, the growth rate of capttal and labor productivities are slowed. Slower productivity advance, in conjunction with the limited avallabilities of capital and labor, means that the growth of total final output is slowed. This is matched by a slowing in the growth of real incomes.

In addition to changes in final spending patterns, the composition of factor inputs into production is also projected to change substantial1y. The structure of inputs is shown in Table 3.10 in terms of the inputs of capital, labor, energy, and intermediate materials per unit of aggregate output. These data show a continuation of the historical trends toward greater capital intensity and lower labor intensity.

Table 3.10

Aggregate Economic Input Patterns;

Share Coefficients for Aggregate Output: Reference Case

\begin{tabular}{llllll}
\hline & 1980 & 1990 & 2000 & 2010 & 2025 \\
\hline Input coefficient & .1505 & .1789 & .2044 & .2136 & .2611 \\
$\quad$ Capital & .2273 & .2077 & .1829 & .1746 & .1405 \\
Labor & .0314 & .0289 & .0279 & .0300 & .0253 \\
Energy & .5908 & .5844 &. .5848 & .5819 & .5731 \\
Materials & & & & & \\
\hline
\end{tabular}

Equally important is the general downward trend in the intensity of energy use in aggregate production. This is evidenced by reductions in energy's share of total inputs and the energy-capital ratio. This declining intensity of energy use underlies the increase in the overall economic efficiency of energy consumption as measured by the energy-GNP ratio. The only exception to this pattern appears over the period 20002010 when growth in primary energy consumption is relatively more rapid. There is significant growth in the synthetic fuels industries and the long-run adjustiments to relatively more efficient fossil fuel electricgenerating technologies is only partially complete. Hence, this period is characterized by relatively large conversion losses in energy supply. 
Further, with the acceleration of the decline in domestic oll and gas production, there is a relative increase in the growth of the consumption of fuels provided by indirect means. Finally, the growth in direct coal combustion is dampened by the increased competition for coal resources and the limited substitution possibilities associated with feasible penetrations of advanced coal technologles for industrial applications. For these reasons, there is a slight increase in energy's share of total inputs. After 2010, however, these trends are either reversed or their relative strength is diminished so that energy again becomes less important.

of these changes in input patterns, two are particularly important. The first is the changing composition of output from the economy. As already indicated, shifts in the pattern of final demand purchases affect relative factor demands and the rates of growth in factor productivity. The second concerns the patterns of relative price changes. In general, the prices of labor and energy continue to increase rapidly whereas the price of capital services increases more slowly. This motivates the adjustment of input patterns toward capital while economizing on labor and energy.

In summary, the principal features of the reference projection regarding the growth and structure of the U.S. economy are as follows:

- positive economic growth continues but at a declining rate;

- productivity growth becomes relatively more important as labor force expansion slows;

- the pattern of final spending changes only slightly, with consumption increasing in relative importance;

- there is long-run structural change in what is produced as the shares of final spending on agricultural, extractive, construction, and energy outputs diminish and those for transportation, communications, trade, and seivices increase;

- there is also long-run structural change in terms of how output is produced with reductions in the relative importance of labor and energy and an increase in the relative importance of capital services.

\subsubsection{Energy System Development}

Energy service demands. The level and growth of the total nonsubstitutable functional energy service demands consistent with the economic conditions discussed above are presenced 1u Table 3.11. Total energy service demand grows from 32.9 quads in 1980 to 54.0 quads in 2000 , an average annual rate of about 2.5 percent. Demand for energy services in the post-2000 period grows more slowly, 1.5 percent per year, reflecting the lower growth path of economic activity in this period. By 2025 , total energy service demand reaches a level of 77.6 quads.

The detalled breakdown of the energy service demands is presented in Table 3.12. In the pre-2000 period, Industrial energy demand grows more quickly than residential/commercial and transportation demand. The more rapid growth in industrial demand is due largely to the increasing importance of the petrochemicals sector, tempered somewhat by slower growth in process heat requirements. While the commercial sector of the economy becomes more and more 1mportant over time, that role is not reflected 


\begin{tabular}{ccc} 
Table 3.11 & $\begin{array}{c}\text { The Level and Growth of } \\
\text { Total Energy Service Demand: } \\
\text { Reference Case }\end{array}$ \\
\hline Year & $\begin{array}{c}\text { Level of demand } \\
\text { (quadri11ion Btu) }\end{array}$ & $\begin{array}{c}\text { Growth of demand } \\
\text { (percent per year) }\end{array}$ \\
\hline 1980 & 32.9 & \\
1990 & 43.4 & 2.81 \\
2000 & 54.0 & 2.20 \\
2010 & 62.6 & 1.49 \\
2025 & 77.6 & 1.45 \\
\hline
\end{tabular}

Table 3.12

Energy Service Demands:

Reference Case

(Quadrillion Btu)

\begin{tabular}{|c|c|c|c|c|c|}
\hline & 1980 & 1990 & 2000 & 2010 & 2025 \\
\hline \multicolumn{6}{|l|}{ Residential/commercial } \\
\hline Space conditioning & 6.6 & 9.2 & 12.2 & 13.9 & 17.4 \\
\hline Miscellaneous thermal & 1.9 & 2.2 & 2.4 & 2.5 & 2.7 \\
\hline Miscellaneous electric & 2.2 & 2.5 & 3.0 & 3.7 & 4.7 \\
\hline $\begin{array}{l}\text { Subtotal* } \\
\text { Industrial }\end{array}$ & $\overline{10.7}$ & $\overline{14.0}$ & $\overline{17.6}$ & $\overline{20.0}$ & $\overline{24.9}$ \\
\hline Process heat & 9.6 & 12.4 & 15.0 & 16.8 & 20.7 \\
\hline Aluminum & 0.2 & 0.3 & 0.4 & 0.4 & 0.5 \\
\hline Iron and steel & 0.6 & 0.8 & 0.9 & 1.2 & 1.6 \\
\hline Miscellaneous electric & 2.8 & 4.1 & 5.2 & 6.4 & 7.8 \\
\hline Petrochemicals & 4.8 & 6.5 & 8.5 & 10.4 & 12.9 \\
\hline Sub total* & $\overline{18.0}$ & $\overline{24.0}$ & 30.0 & $\overline{35.2}$ & $\overline{43.6}$ \\
\hline \multicolumn{6}{|l|}{ Transportation } \\
\hline $\begin{array}{l}\text { Private ground transport } \\
\text { Truck, bus, rail, }\end{array}$ & 2.0 & 2.3 & 2,5 & 3.1 & 3.9 \\
\hline and ship & 1.5 & 1.7 & 1.9 & 2.3 & 2.9 \\
\hline Air transport & 0.7 & 1.3 & 1.7 & 1.7 & 2.2 \\
\hline Electric rail & 0.1 & 0.1 & 0.2 & 0.2 & 0.2 \\
\hline Subtotal* & $\overline{4.2}$ & 5.4 & 6.4 & 7.3 & 9.1 \\
\hline $\begin{array}{l}\text { Total energy service } \\
\text { demand* }\end{array}$ & 32.9 & 43.4 & 54.0 & 62.6 & 77.6 \\
\hline :alo may not add beca & I & 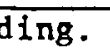 & & & \\
\hline
\end{tabular}


here because of the aggregation with the residential sector, where slower population growth holds down the demands in this large category. The transportation sector's importance in the economy is tempered somewhat over time as reflected in the decrease in its share of energy service demands. Within this energy-intensive sector, there is a slight shift over time away from private ground transportation toward the air, bus, and electric rail modes for passenger traffic. The shares of these energy service demands as a percent of total energy demand appear in Table 3.13.

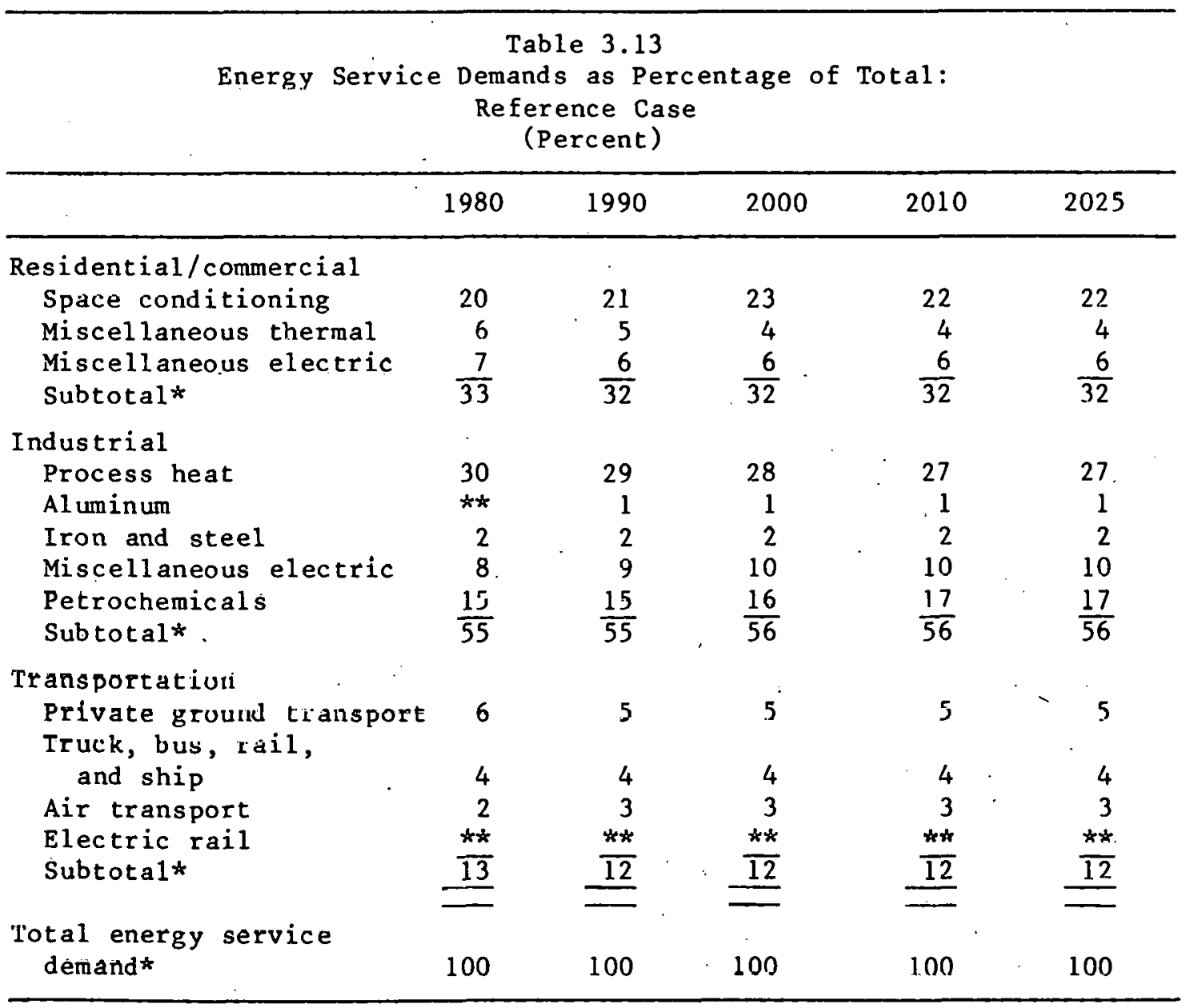

* Totals may not add because of rounding.

$* *$ Less than 0.5 percent.

In the post-2000 period, the structure of energy services remains fairly stable, primarily because of the stability in the structure of economic activity and the moderation of the growth in the aggregate price of energy. 
Delivered energy prices and quantities. Because of continued increases in the prices of refined petroleum products, and the rigid set of oil import quota constraints, there is a continued shift away from oil-intensive demands over time. The share of delivered fuels used for transportation services declines significantly from 35 percent in 1980 to 29 and 27 percent in the years 2000 and 2025, respectively. Throughout the time period transportation service demands are increasingly met by electric cars, electric rail, and methanol-fueled vehicles. The residential/commercial sector maintains a relatively constant share of total delivered fuels, ranging from 22 to 25 percent in all years. 0il products in this sector are displaced primarily by electricity and delivered gas products. Industrial energy consumption is projected to increase its share of total delivered fuels about 25 percent above its 1980 share of 41 percent by the end of the projection period. Increased burning of coal and wood and the use of waste heat from cogeneration enables the industrial sector to substitute away from the direct combustion of refined oil products.

Delivered energy consumption in the reference case is projected to rise from a 1980 level of 59 quadrillion Btu to 86 quads by the year 2000 , and to 101 quads by the year 2025, increasing at an average annual rate of 1.2 percent in both the pre- and post-2000 periods. Throughout the projection period, there is continued substitution away from petroleum products and a trend toward the increased electrification of the energy system.

Table 3.14

Delivered Energy Quantities by

Aggregate Economic Sector:

Reference Case

(Quadrillion Btu)

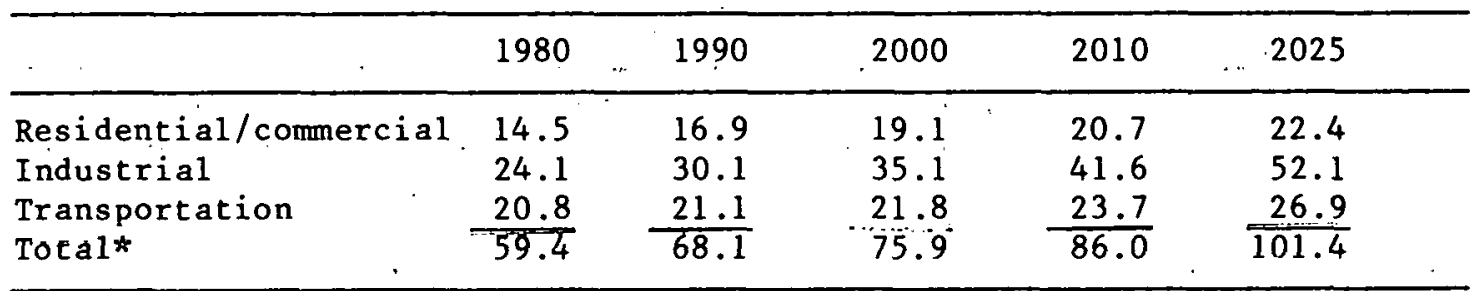

*Totals may not add because of rounding.

The composition of delivered fuels changes significantly as a result of interfuel substitution and the changing pattern of energy services over time. Electricity's share of total delivered energy rises from 14 percent in 1980 to 20 percent by the year 2025. Gas usage maintains a relatively constant share of delivered fuels, ranging from 22 to 26 percent, but the proportion of total, delivered gas that is synthetic increases over time. Direct solar, geothermal, and waste heat play an 
Table 3.15

Delivered Energy Shares by

Aggregate Economic Sector:

Reference Case

(Percent)

\begin{tabular}{lccccc}
\hline & 1980 & 1990 & 2000 & 2010 & 2025 \\
\hline Residential/commercial & 24 & 25 & 25 & 24 & 22 \\
Industrial & 41 & 44 & 46 & 48 & 51 \\
Transportation & $\frac{35}{100}$ & $\frac{31}{100}$ & $\frac{29}{100}$ & $\frac{28}{100}$ & $\frac{27}{100}$ \\
Total* & 100 \\
\hline
\end{tabular}

*Totals may not add because of rounding.

increasingly larger role and provide 8 percent of delivered energy by 2000. The solid fuel share of total delivered energy more than doubles by the year 2025 because of the increasing use of coal for industrial process heatng and of wood stoves for space heating. Oil and methanol shares decline rapidly from 53 percent in 1980 to 34 and $28^{\text {'percent of }}$ total delivered fuels in the years 2000 and 2025 , respectively. However, in spite of these large reductions in the share of delivered energy, liquid fuels continue to account for the largest share of total delivered fuels in all years.

Table 3.16

Delivered Energy Quantities by Fuel Type:

Releituce case

(Quadrillion Btu)

\begin{tabular}{lrrrrr}
\hline & 1980 & 1990 & 2000 & 2010 & 2025 \\
\hline Coal, coke, wood & 6 & 11 & 12 & 15 & 23 \\
Oil, methanol & 31 & 26 & 26 & 28 & 28 \\
Aas, lo-Btu gac & 14 & 8 & 18 & 21 & 22 \\
Electricity & 8 & 11 & 15 & 17 & 21 \\
$\begin{array}{l}\text { Direct solar, georhermal, } \\
\quad \text { waste heat }\end{array}$ & $* \star$ & 1 & 6 & 5 & 8 \\
Total* & 59 & 68 & 76 & 86 & 101 \\
\hline
\end{tabular}

*Totals may not add because of rounding.

$*$ Less than 0.5 quad. 
The prices of delivered fuels and electricity are given in Table 3.17. The average delivered price of energy is computed as a quantityweighted average of the prices of delivered oil, gas, coal, wood, direct solar, geothermal and waste heat, and electricity. Over the 1980 to 2000 perlod, the average delivered price of energy rise from $\$ 3.68$ in constant 1972 dollars per million Btu to $\$ 5.30$, increasing at an average annual rate of 1.8 percent. In the TESOM model specification, markups of delivered fuels to end-use categorles were held constant over time. Therefore the delivered price rises less rapidly than the average supply price, which increases at a 2.1 percent annual rate during the same perlod. Over the first quarter of the next century, delivered energy prices are anticipated to to remain fairly constant and reach $\$ 5.31$ in 2025 .

Table 3.17

Delivered Energy Prices:

Reference Case

(1972\$/Million Btu)

\begin{tabular}{lccccc}
\hline & 1980 & 1990 & 2000 & 2010 & 2025 \\
\hline Delivered coal & 0.86 & 1.08 & 1.36 & 1.39 & 1.42 \\
Delivered coke & 1.94 & 2.12 & 2.21 & 2.11 & 2.50 \\
Delivered oil & 3.59 & 4.25 & 5.31 & 5.81 & 6.65 \\
Delivered gas & 1.36 & 3.90 & 4.52 & 4.40 & 4.29 \\
$\begin{array}{l}\text { Delivered electricity } \\
\text { Direct solar \& }\end{array}$ & 9.63 & 10.03 & 10.33 & 10.59 & 10.91 \\
$\quad \begin{array}{l}\text { geothermal } \\
\text { Delivered waste heat }\end{array}$ & -- & -- & -- & -- & -- \\
$\begin{array}{l}\text { Delivered lo-Btu gas } \\
\text { Delivered wood }\end{array}$ & -- & 4.23 & 4.43 & 5.73 & 5.07 \\
$\begin{array}{l}\text { Delivered methanol } \\
\text { Average delivered }\end{array}$ & -- & 1.44 & 1.40 & 1.36 & 1.18 \\
$\quad$ price & 3.68 & 4.61 & 2.04 & 2.12 & 2.26 \\
& & 5.07 & 5.07 & 5.26 & 5.00 \\
\hline
\end{tabular}

The price of delivered coal rises from $\$ 0.86$ in 1980 to $\$ 1.36$ by 2000 , increasing at an average annual rate of 2.3 percent. After 2000, the annual growth olowg to 0.2 percent and the price reaches $\$ 1.42$ in 2025 .

The average price of delivered oll products, computed as a quantityweighted average of the prices for gasoline, kerosine, distilate, and residual fuels, increases at an average annual rate of 0.6 percent from 1980 to 2000 . From a year 2000 price of $\$ 5.31$ per million Btu, the price of delivered ofl products increases by $\$ 1: 34$ to reach $\$ 6.65$ by the year 2025 , a considerably smaller increase than the $\$ 2.96$ rise in the price of crude petroleum during the same time period. This moderation is the result of a rise in the share of relatively less expensive coal liquids over this pertod. 
The price of delivered gas products is an average of the prices for residential/commercial and industrial users of gas products. The delivered gas price rises rapidly in the pre-2000 period, as natural gas prices are deregulated, and grows from $\$ 1.36$ per million Btu in 1980 to $\$ 4.52$ by 2000 . By 2025 , the share of synthetic gas increases to account for two thirds total delivered consumption. As a result of the growth in synthetic gas production, the average price of delivered gas decreases in the post-2000 period to $\$ 4.29$ by the year 2025 .

Electricity prices remain relatively stable during the 1980 to 1990 period, rising from a 1980 price of $\$ 9.63$ to $\$ 10.03$ by 1990 . After 1990 , the introduction of electric district heating and industrial cogeneration plants results in the production of waste heat, in addition to generated electricity, at a cost below those for conventional plants. The electricity price grows to $\$ 10.33$ by the year 2000 and to $\$ 10.91$ per million Btu by the year 2025 .

Electricity Generation. Increased electrification of the energy system is projected over the 1980 to 2000 period for the reference case in response to higher oil and gas prices and increased availabilities of efficient new electric generation technologies. Total refined fuel inputs to electricity grow at an average annual rate of 2.8 percent over this period. This rate of growth exceeds the 1.4 percent growth in total primary energy and results in an increased degree of electrifiction of the energy system from 33 percent in 1980 to 43 percent by the year 2000. Because of the high degree of substitution of synthetic liquid and gaseous fuels after 2000 , the growth in electricity generation moderates after 2000. During the 2000 to 2025 period, electric inputs rise at an average annual rate of 1.4 percent from 47 quads to 61 quads by the year 2025. The degree of electrification of the system during the post-2000 period declines from 43 percent in 2000 to 38 percent by 2025 , but remains well above the present 33 perccnt. The pattern of inputs to electricity generation changes significantly over the projection period, as shown in Table 3.18 .

Throughout the projection period, coal remains the duminant fucl input to electricity generation, accounting for 50.1 percent of total refined input in 1980, and increasing to 51.7 percent by 2000 . Ndvanced coal systems begin to penetrate the electric sector in 1990 , and account for 9.7 of the total 10.5 quadrillion Btu increase in coal electric inputs over the 1980-2000 period. Advanced coal systems included in the electric technology mix for the year 2000 include atmospheric and pressurized fluidized-bed central stalion systcmo, coal steam and fludiziedbed district heating, and cogeneration facilities.

Nuclear electric inputs are projected to increase al an averagc annual rate of 6.5 percent over the pre-2000 period to 11.7 quads in 2000 . Nuclear generation capacicy was constrained in the reference case to provide 225 to $2 / 10$ yigawitta of electricity for the year 2000 .

As coal, nuclear, and nonfossil electric inputs are substituted intu the electric fuel mix, oil and gas inputs decline sharply. Aggregate oil and gas inputs to steam and turbine technologies decrease from 6.1 quads in 1980 to 1.9 quads by the year 2000. The combined share of oil and gas inputs to electric generation declines from 23 percent in 1980 to 4 percent by the year 2000 . 


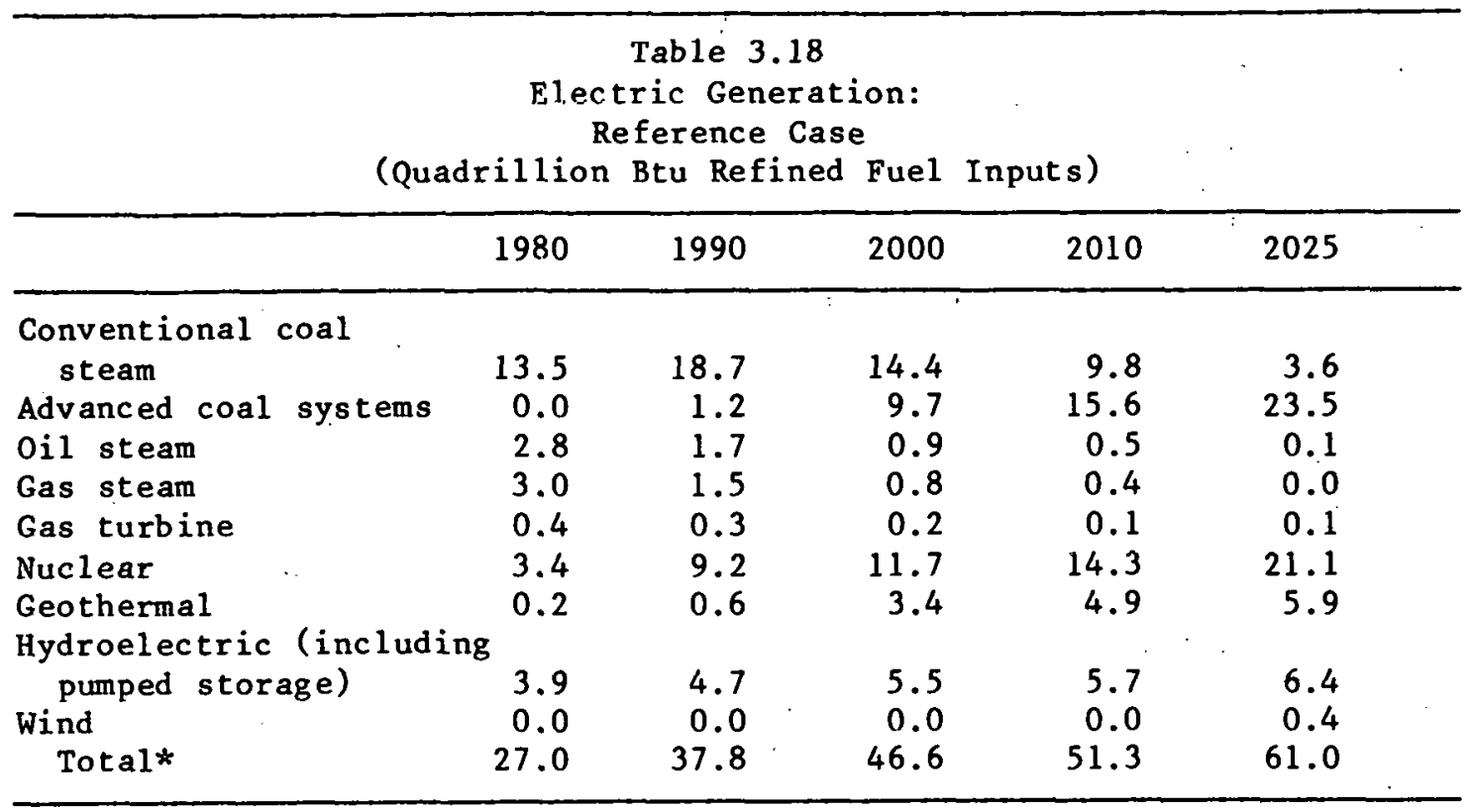

* Total may not add because of rounding.

Renewable electric technologies account for an increasingly larger share of total generation over time. Hydroelectric and geothermal electric inputs account for 8.9 quads or 19 percent of total generation in 2000 , as compared with a renewable electric share of 15 percent in 1980. Hydro inputs rise less rapidly than total electric inputs, while geothermal electric inputs increase at an average annual .rate of 15.6 percent to account for 3.4 quads by 2000 . The shares of refined fuel inputs to electricity generation are given in Table 3.19.

Table 3.19

Electric Generation Fuel Shares:

Reference Case

(Percent)

\begin{tabular}{lrrrrr}
\hline & 1980 & 1990 & 2000 & 2010 & 2025 \\
\hline Coal & 50 & 53 & 52 & 50 & 44 \\
Oil & 10 & 4 & 2 & 1 & $* *$ \\
Gas & 12 & 5 & 2 & 1 & $\star *$ \\
Nuclear & 12 & 24 & 25 & 28 & 35 \\
Hydroelectric & 14 & 12 & 12 & 11 & 10 \\
Other renewable & 1 & 2 & 7 & 10 & 10 \\
$\quad$ Total* & 100 & 100 & 100 & 100 & 100 \\
\hline
\end{tabular}

*Totals may not add because of rounding.

**Less than 0.5 percent. 
During the post-2000 period, the aggregate share of coal and nuclear inputs remains relatively constant, ranging from 77 to 79 percent of total electric inputs. Coal electric generation is projected to rise less rapidly than total electric production over the 2000 to 2025 period, and results in a decline in the aggregate coal input share from 52 to 44 percent. The absolute level of coal inputs rises 3 quads over the 2000 to 2025 period, with advanced coal technologies contributing 23.5 quads of the total 27 quads of coal inputs to electricity by 2025 .

Conventional central station fossil electric plants are reduced significantly from the levels provided in the year 2000. Aggregate inputs for coal, o11, and gas steam plants decrease from 16 quadrillion Btu to 3.7 quads. Renewable energy inputs, including hydro, geothermal, and wind, Increase from 8.9 to 12.8 quads over the $2000-2025$ period and account for 20 percent of total inputs to electricity generation by the end of the projection period.

Synthetic Fuels. In the reference case projection, synthetic 11quids and gases penetrate the system at levels of 0.6 quads each by the year 1990. Synthetic liquids account for 2.2 percent of total 11quids consumed in 1990, and syntheric gases provile 2.8 pereent of total gaseous fuel requirements. The production of synthetic fuels accelerates during the 1990-2000 period, as the synfuels industries replace imported oll supplies that were previously restricted in accordance with the quotas. Synthetic liquids grow at an average annual rate of 21.5 percent from 1990 to 2000 to 2.1 quads, and provide 8 percent of total delivered 1iquids by 2000 . Synthetic gases increase similarly, rising from 0.6 to 4.3 quads by 2000 , at an average rate of 21.8 percent, to account for 23 percent of total gaseous fuels consumed in the year 2000 . The production levels for synthetic fuels are given in Table 3.20 for the years 1990, 2000 , and 2025.

Table 3.20

Synthet1c Fuel Production Levelo:

Reference Case

(Quadrillion Btu of output)

\begin{tabular}{llll}
\hline & 1990 & 2000 & 2025 \\
\hline Synthelfe liquids & & & \\
Coal liquids & 0.2 & 1.4 & 8.1 \\
Coal methanol & 0.1 & 0.8 & 5.0 \\
Shale ofl & 0.3 & 0.7 & 2.0 \\
Total synthetic 11quids* & 0.6 & 2.9 & 15.1 \\
Synthetle gases & & & \\
Coal gas & 0.6 & 4.2 & 14.5 \\
Unconventional gas & 0.0 & 0.0 & 0.0 \\
Blomass gas & 0.0 & 0.1 & 0.1 \\
Total synthetic gases* & 0.6 & 4.3 & 14.5 \\
Total synthetic fuels* & 1.1 & 7.2 & 29.6 \\
\hline
\end{tabular}

*Totals may not add because of rounding. 
After 2000 , the production of synthetic fuels grows less rapidiy, as aggregate energy demands increase less rapidly than during the 1980-2000 period. Total synthetic liquids increase at an average rate of 6.8 percent per year to 15.1 quads by 2025. Synthetic gases grow at 5.0 percent per year to 14.5 quads by the year 2025. By the end of the projection period, domestically produced synthetic fuels are expected to account for 29 percent of total delivery energy consumption in the reference case.

Primary Energy. Total consumption of primary energy resources is projected to reach 109 quads by the end of the century. Over the 1.980-1990 period, the usage of primary energy grows at 1.7 percent per year, but slows to an annual rate of 1.2 percent over the next ten years. This slowdown in the growth of primary energy results from the increasing ablifty of the energy-utilizing capital stock to respond to increasing relative prices. After the year 2000, primary energy consumption accelerates as the system moves toward the less efficient coal syntheric fuels. As these technologies saturate the system, primary energy consumption growth slows somewhat, reaching 158 quads in 2025. Primary resource use and its annual growth rates appears in Table 3.21.

Table 3.21

Total Primary Energy Usage and Average Price: Reference Case

\begin{tabular}{lcccc}
\hline Year & $\begin{array}{c}\text { Usage } \\
\left(10^{15} \text { Btu }\right)\end{array}$ & $\begin{array}{c}\text { Average annual } \\
\text { growth rate } \\
\text { (percent) }\end{array}$ & $\begin{array}{c}\text { Average } \\
\text { price } \\
\left(1972 \$ / 10^{6}\right.\end{array}$ & $\begin{array}{c}\text { Average annual } \\
\text { Browth rate } \\
\text { (percent) }\end{array}$ \\
\hline 1980 & 82.0 & & 1.53 & \\
1990 & 96.9 & 1.7 & 2.02 & 2.8 \\
2000 & 109.4 & 1.2 & 2.32 & 1.4 \\
2010 & 130.7 & 1.8 & 2.20 & -0.5 \\
2025 & 158.5 & 1.3 & 2.06 & -0.4 \\
\hline
\end{tabular}

The average primary energy supply price grows from $\$ 1.53$ in 1980 (measured in constant 1972 dollars per million Btu) to $\$ 2.32$ in 2000 , or at an average annual rate of 2.1 percent. This is a quantity-weighted average of the exogenously specifled prices (see above) for dnmestir, Imported, and shale ofl; domestic, imported, and unconventional natural gas; coal; uranium; wood; solid waste; and blomass. Thus, the growth in the average supply price depends not only on the growth in the prices of the Individual energy resources, but also on the changing importance of these resources as the energy system shifts away from those supplles with the higher and accelerating prices toward those with relatively lower prices and/or slower price growth. In the post-2000 period, as more of the relatively less expensive resources are used, the average supply price actually declines, at an average annual rate of 0.5 percent, to $\$ 2.06$ in 2025. (The Individual resource price assumptions are discussed above and appear in Table 3.3.) 
The price of domestic and imported ofl grows at an annual rate of 3.3 percent in the pre-2000 period, and slows to 2.1 percent thereafter. These price increases result in decreasing dependence on this conventional liquid resource, with its use declining by an average rate of 2.0 percent per year in the 1980-2000 perfod and by 2.4 percent in subsequent years. (See Tables 3.22 and 3.23.). Conventional o11's share of total resource consumption drops from 46 percent in 1980 to 24 percent in 2000 and to 8 percent in 2025. However, our dependence on liquid fuels is not mitigated by the higher oil prices and the trend away from conventional o11. Increasing usage of shale oil and synthetic liquid fuels from coal In the post-2000 period allows the continuation of our dependence on liquid fuels.

A similar story emerges for natural gas usage. Rapid price increases in the pre-2000 period, which continue, albeit at a slower rate, thereafter, result in. decreasing dependence on this resource. Natural gas usage drops from 22 percent of total primary energy in 1980 to 14 and

Table 3.22

Primary Energy Usage:

Reference Case

(Quadri11ion Btu)

\begin{tabular}{|c|c|c|c|c|c|c|c|c|c|c|}
\hline . & & 1980 & & 1990 & 2000 & & 2010 & . & 2025 & \\
\hline \multicolumn{11}{|l|}{ Nonrenewable } \\
\hline Oi1-domestic & & 21.0 & . & 19.3 & 16.1 & & 12.6 & & 7.9 & \\
\hline imported & & 16.2 & & 9.2 & 8.4 & & 7.3 & & 5.4 & \\
\hline shale & & 0.0 & & 0.3 & 0.8 & & 1.2 & & 2.0 & \\
\hline Gas-domestic & & 17.7 & & 17.6 & 15.0 & & $12 . n$ & & 7.7 & \\
\hline Imported & & 0.0 & & 2.8 & 0.0 & & 0.0 & & 0.0 & \\
\hline unconventional & & 0.0 & & 0.0 & 0.0 & & 0.0 & · & 0.0 & \\
\hline Coal & & 18.2 & & 29.8 & 42.1 & & 64.3 & & 89.8 & \\
\hline Ưranıum & & 3.4 & & 92 & 11.7 . & & 14.3 & & 21.1 & \\
\hline Subtotal* & & $7 \overline{76.5}$ & & 88.1 & $\overline{94.2}$ & & $\overline{111.6}$ & & $\overline{134.0}$ & \\
\hline Renewables & . & , & & & & & & & . . & \\
\hline Wood & & 1.5 & & 2.6 & 4.3 & & 5.5 & & 6.9 & \\
\hline Solld waste & & 0.0 & & 0.0 & 0.0 & : & 0.0 & & $0: 0$ & \\
\hline Blomass & & 0.0 & & 0.0 & 0.2 & & 0.2 & & 0.2 & \\
\hline Hydroelectric & & 3.8 & & 4.6 & 5.3 & & 5.6 & & 6.2 & \\
\hline Geothermal & & 0.2 & & 0.9 & 4.1 & & 5.9 & & 7.5 & . \\
\hline Solar & & $\star \star$ & , & 0.6 & 1.4 & & 2.0 & & 3.3 & $\cdot$ \\
\hline Wind & & 0.0 & & 0.0 & 0.0 & & 0.0 & & 0.4 & \\
\hline Subtotal* & & $\overline{5.5}$ & & 8.8 & 15.2 & & $1 \overline{19.1}$ & & 24.5 & $:$ \\
\hline Total* & & 82.0 & & 96.9 & 109.4 & . & 130.7 & & 158.5 & \\
\hline Imports & & 16.2 & & $12.0^{\circ}$ & 8.4 & & $7 . .3$ & & 5.4 & \\
\hline
\end{tabular}

*Totals may not add because of rounding. $\star *$ Less than 0.5 quads. 


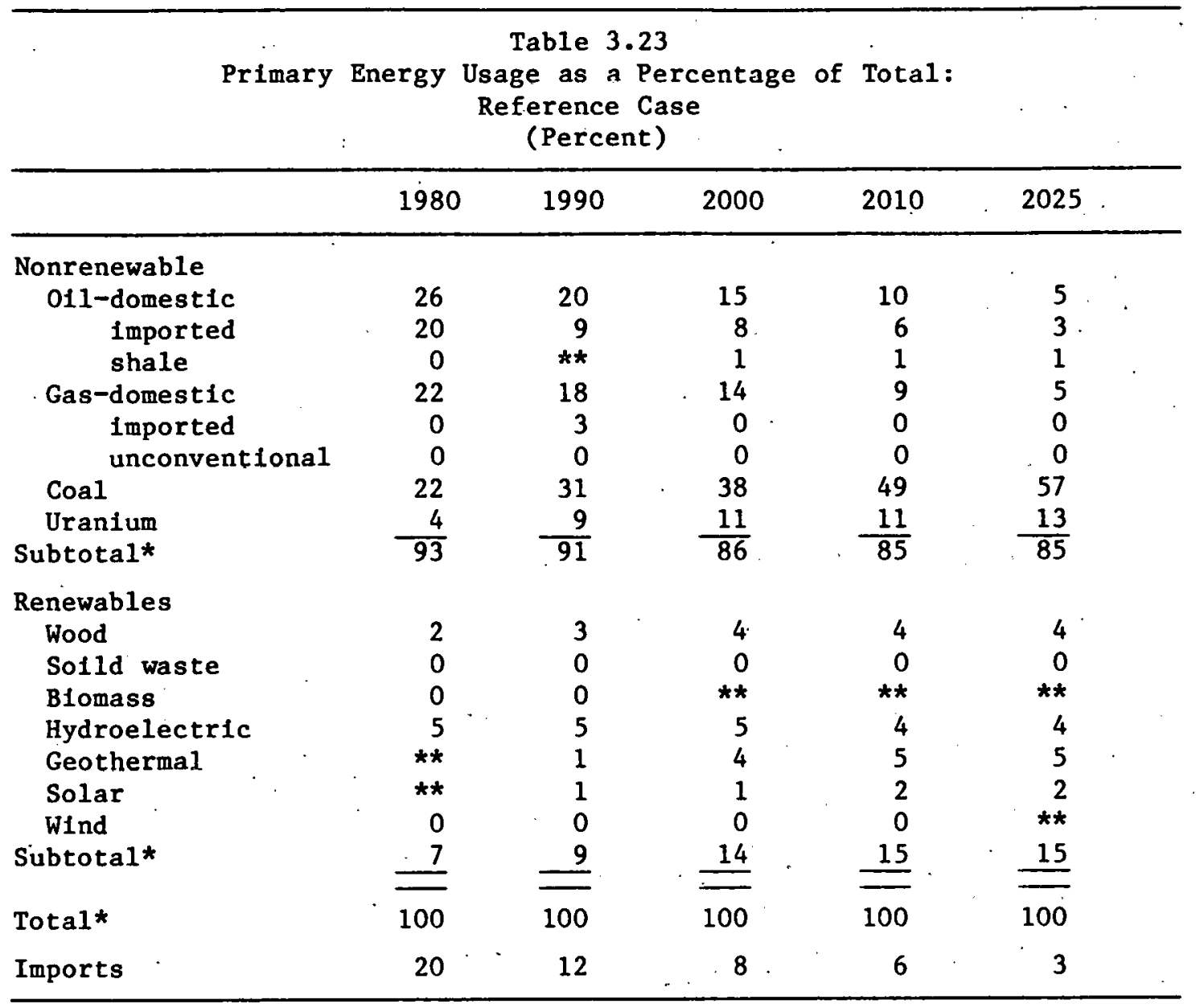

*Totals may not add because of rounding.

**Less than 0.5 percent.

5 percent in 2000 and 2025, respectively. However, as with fossil 1iquids, synthetic gases play an increasingly important role in our energy picture.

The nation'o dependerice on imported ofl and gas declines substantially over the projection period. The energy system is able to meet President Carter's goal of 9.2 quads of Imported oil in 1990, but only at the cost of 1mporting 2.8 quads of natural gas in that year. After 1990, sufficlent synthetic liquids and gases become avallable and gas imports return to zero. 0il imports continue throughout the timeframe as declines in domestic production cannot be offset by synthetic liquids.

Coal usage expands rapidly throughout the projection period. Its supply price increases at a rate substantially below that of any other nonrenewable resource. The use of coal for providing synthetic liquids and gases as well as electricity grows continually thorugh 2025. In the pre-2000 period, coal usage grows at an average annual rate of 4.3 percent and provides 38 percent of our primary energy needs in the year 2000 , replacing ofl as our most important energy resource. In the 
post-2000 period, coal consumption grows at the lower annual rate of 3.1 percent as shale ofl and the renewable energy sources increase in Importance.

The role of uranium in meeting our energy needs was constrained to about 12 quads in 2000 and 21 quads in 2025, as discussed above. It thus provides 11 and 13 percent of our primary energy needs in 2000 and 2025, respectively.

Overall, nonrenewable energy resources become less and less 1mportant. This decline is fairly rapid in the pre-2000 period as the share of primary resource use from nonrenewables falls from 93 percent in 1980 to 86 percent in 2000. The role of nonrenewables stabilizes at around 85 percent in the post-2000 period as no further constraints on the availability of nonrenewables or rapid changes in relative energy prices occur.

The 1ncreasing Importance of renewable energy resources ( 7,14 , and 15 percent in 1980,2000 , and 2025, respectively) results in a fairly broad range of new technologies and supplies. The only renewable source share of primary energy declining over time is hydroelectric, as its avallability is somewhat constrained. Its share declines from around 5 percent in the pre-2000 period to around 4 percent in the post-2000 period. The use of wood for both direct heat and electricity generation increases almost three-fold by the year 2000 and provides 4 percent of primary energy, maintalning this share through 2025. Biomass is used for electricity generation but provides only a small portion of our resource needs. Geothermal energy for heating and electricity generation grows rapidly from an insignificant level in 1980 to 4 quads in 2000 and almost 8 quads in 2025 ( 4 and 5 percent of total, respectively). Direct heat from solar grows slowly; reaching 1.4 quads in 2000 and 3.3 quads in 2025. Wind makes a small contribution to primary energy needs in 2025.

Energy system efficlencies. Aggregate meosures of efficlency for energy conversion and utilization are presented in Table 3.24. Included are measures of efficiencles from primary resources to delivered fuels, from delivered fuels to energy services, and an overall systeur-wide efficiency of energy services provided per unit of primary energy.

Table 3.24

Aggregate Energy Quantities and System Efficiencies: Reference Case

\begin{tabular}{lrrrrr}
\hline & 1980 & 1990 & 2000 & 2010 & 2025 \\
\hline Eneigy quantities (quads) & & & & & \\
I Total primary energy & 82.0 & 96.9 & 109.4 & 130.7 & 158.5 \\
II Total delivered energy & 59.4 & 68.1 & 75.9 & 86.0 & 101.4 \\
III Total energy services & 32.9 & 43.4 & 54.0 & 62.6 & 77.6 \\
Aggregate efficiencies & & & & & \\
II/I Average supply efficiency & .73 & .70 & .69 & .66 & .64 \\
III/II Average demand efficiency & .55 & .64 & .71 & .73 & .77 \\
III/I Average system efficiency & .40 & .45 & .49 & .48 & .49 \\
\hline
\end{tabular}


These efficiency indicators change over time as a result of the following:

- Projected improvements in efficiencies of conventional end-use devices and electricity generation.

- Introduction of new energy supply, conversion, and end-use technologies.

- Substitution of electricity, synthetic fuels, and renewable energy sources for oil.

- Changes in the structure of energy service demands over time.

The combined impacts over time of an increasing degree of electrification and the growth of synthetic fuels production account for the reduction in the amount of delivered energy obtained from each Btu of primary energy, as indicated by the declining average supply efficiency. These decreases in efficiency are offset by significant improvements in the average efficiencies of end-use devices. The replacement of vintage capital stocks and substitution for conventional fuels of those having relatively higher efficiencies at end-use conversion, such as electricity and solar, lead to a rising average demand efficiency over time. The average energy system efficiency for the reference case is projected to increase at an average annual rate of 1.0 percent from 1980 . to 2000 , during the transition away from use of conventional liquids towards relatively less expensive and more efficient fuels and devices, and remains relatively constant thereafter.

3.3.4 Environmental Conditions. The environmental indicators for the reference projection appear in Table 3.25. These indicators reflect the differing levels of air- and waterborne emissions, occupational safety (person-days lost because of deaths and injuries), and nuclear radiation (population exposure). The actual effects of these measures on the quality of the environment and the health of the population depend on the geographic location of the producers of the air, water, and radiation emissions as well as on the location of the receptors. These geographic distributions are difficult to project over the timeframe of concern here, and impossible to ascertain from an aggregate national modeling approach. However, it is known that the levels of emissions and their environmental and health effects are correlated: higher emissions levels have larger negative effects on environment and health. The environmental information provided here should be used solely to compare the relative effects of alternative projections on these measures and the qualitative differences in their environmental effects.

The reference projection results in increasing levels of all environmental and health measures over time. The assumption that current best available control technologies are used on all technologies and that the performance of the controls remains constant over time results in the levels of the measures increasing directly with the activity level of the energy technologies. The mix of emissions changes as the mix of energy technologies shifts.

Air emissions (particulates, nitrogen oxide, sulfur dioxide, hydrocarbons, carbon monoxide) are largely dependent on the levels of. fuel burning for electric generation, transportation, and heat requirements. The shift towards more coal-fired plants for electric generation (and fewer oil and gas plants) with their relatively higher air emissions is 
Table 3.25

Environmental Indicators:

Reference Projection

\begin{tabular}{lrrrrc}
\hline & 1980 & 1990 & 2000 & 2010 & \multicolumn{1}{c}{2025} \\
\hline $\begin{array}{l}\text { Airborne emissions, } \\
10^{6} \text { tons }\end{array}$ & 31.6 & 34.5 & 39.5 & 54.3 & 72.6 \\
$\begin{array}{l}\text { Waterborne emissions } \\
\quad 10^{6} \text { tons }\end{array}$ & 1.1 & 1.0 & 2.3 & 2.8 & 4.0 \\
$\begin{array}{l}\text { Person-days lost, } \\
\quad 10^{3} \text { person days }\end{array}$ & 485.8 & 667.0 & 903.8 & 1308.2 & 1377.1 \\
$\begin{array}{l}\text { Population exposure, } \\
10^{6} \text { man-rem }\end{array}$ & 0.3 & 0.7 & 0.9 & 1.1 & 1.7 \\
\hline
\end{tabular}

the major cause of increased air pollution. The trend towards greater fuel efficiency in the transportation sector results in a tempering of this sector's contribution to air emissions over time.

The water emissions (acids, bases, phosphates, suspended solids, non-degradable organics, BOD, COD) are predominately related to coal mining and shale oil production, but also result from synthetic fuel conversion. The increasing activity levels of these technologies drive the increases in waterborne emissions. The water requirements for synfuels production were not taken into account as either a constraint or an cffect in this study. Person-days lost becuase of occupational-related accidents are largely dependent on the level of coal mining and the miner injuries and deaths.

The only uranlum using technology in the reference projection is the light water reactor for electric generation. Thus, the population exposure to nuclear radiation depends on the growth in both nuclear capacity and population over the projection period.

\section{CONSERVATION POLICY}

\subsection{Introduction}

In the strategic benefit-cost analysis of energy policico, three major strategies are delineated as possible directions for future energy policy. The first is a strategy of no additional policies or programs beyond thooo currently enacted or announced and under direct control of the Exerutive Branch. The second strategy is to direcl policy toward reducing demand growth, i.e., titergy conocrvalion. The third emphasizes increased domestic energy supply, primarily through an accelerated development of the so-called synthetic and unconventional fuels. This section presents the detailed analysis of the second of these strategies, namely, the conservation policy. 
Beginning with Fiscal Year 1981 , the conservation policy represents the programmatic and induced, i.e., private sector, expenditures and the associated energy savings of the combined Minimum and Current programs of the Office of Assistant Secretary for Conservation and Solar Applications (CSA). The expenditure and energy information is provided by the Consolidated Ranking of FY 1980 Decision Packages and supporting materials that were prepared by CSA personnel. The incremental energy savings reported for these programs are solely attributable to the post-FY 1980 levels of effort, irrespective of their continuing nature. Thus, the introduction of this policy into the reference projection affords the direct determination of the energy, economic, and environmental consequences of the demand reduction strategy.

The conservation policy, as described in the CSA materials, incorporates subprograms into major program areas as follows:

- Building and Community Systems - Building Systems; Appliance Standards; Community Systems; Urban Waste; Technology and Consumer Products; Analysis and Technology Transfer; Residential Conservation Service; The Federal Energy Management Program (FEMP); Small Business.

- Transportation - Vehicle Propulsion RD\&D; Electric Vehicle RD\&D; Transportation System Utilization; Alternative Fuels Utilization.

- Industrial - Waste Energy Reduction; Industrial Cogeneration; Industrial Process Efficiency; Implementation and Deployment.

- State and Local Programs - Schools and Hospitals; Local Government Buildings; Weatherization Assistance; The Energy Management and Partnership Act (EMPA).

- Appropriate Technology - Small-Scale Technology.

The remainder of this section is organized under three major subheadings. The first presents an overview of the expenditure and energy information for. the CSA initiatives. Included is an analysis of the expenditure data that provides the representation of the annual direct policy costs associated with the yearly energy savings from conservation, and also a description of the application of the BNL/DJA energy-economy model system to this policy representation. Under the second subheading the principal energy, economic, and environmental conditions that characterize the conservation projection are enumerated. Finally, a summary is provided of the impacts on national energy, economic, and environmental objectives that result from a strategic redirection of national energy policy toward conservation.

\subsection{Assumptions and Methodology for the Conservation Case}

The supporting documentation for the conservation policy contains information for each subprogram as to the direct benefits and costs of the particular initiative. The direct policy benefits are represented by the levels of annual energy savings (1985, 1990, and 2000); the direct costs are reflected in the cumulative public and private expenditures, discounted to the present (FY 1981), that are required to achieve the ultimate levels of energy savings. 
The energy displacements induced by the CSA programs are introduced directly into the reference projection. These energy reductions permit the annual release of those resources associated with the production and/ or importation of petroleum, natural gas, and electricity. However, these benefits are not without cost. They result from a temporally phased diversion of productive resources, public and private alike, into those activities implied for each of the conservation initiatives. The annual benefits from conservation policy are measured against the annual claims on the inputs available to the economy. These claims are implicit in the CSA discounted expenditure information and are represented by a reallocation of capital and labor services from other productive uses to energy conservation activities.

The total cost information for each subprogram, shown in Table 4.1, results from the discounting of an annual series of expenditures. Mathematically,

$$
\mathrm{TDC}_{\mathbf{i}}=\sum_{t=0}^{T} \frac{\mathrm{E}_{\mathbf{i}}}{(1+\mathrm{r})^{t}}
$$

where

$$
\begin{aligned}
\mathrm{TDC}_{\mathrm{i}}= & \text { total discounted public and private cost for subprogram } i, \\
\mathrm{E}_{\mathrm{it}}= & \text { annual public and private expenditures induced by subprogram } \\
& \mathrm{i} \text { in year } t \text { (in undiscounted constant dollars), } \\
\mathrm{r}= & \text { the discount rate (taken to be } 10.0 \text { percent), } \\
\mathrm{T}= & \text { the duration of subprogram } i \\
t= & \text { a time index }(0=1981,1=1982, \ldots) .
\end{aligned}
$$

In order to determine the capital and labor services claims due to this policy, it is necessary to

- develop the annual expenditures serico for each suhprogram;

- allocate annual expenditures betwecn investment purchases and labor services expendilures;

- convert the investment expenditures series into a capital services series.

The materials provided by CSA contain annual expenditure information fnr the public sector only and these costs are but a small fraction of the total expenditures devoted to che conservacion dilivitips. Consequently, rules that are specific to each subprogram are required for converting the total discounted costs into an undiscounted expenditure stream. Three types of distribution mechanisms are used to perform this conversion. These are denoted the uniform, constant rate of growth, and trapezoidal distribution patterus. They are depicted graphically with their parameter requirements in Figure 1.

The uniform distribution is chosen for subprograms in which all costs are incurred in the first year, e.g., the Energy Management Partnership ACt (EMPA), and those that require a series of constant annual expenditures for some number of years, e.g., Weatherization Assistance. The costs for these subprograms have virtually no private sector content 


\begin{tabular}{|c|c|c|}
\hline \multicolumn{3}{|c|}{$\begin{array}{c}\text { Table } 4.1 \\
\text { Total Discounted Costs: } \\
\text { Conservation Policy }\end{array}$} \\
\hline Program & $\begin{array}{c}\text { Discounted public and } \\
\text { (millions of } 1972\end{array}$ & $\begin{array}{l}\text { d private cost } \\
\text { dollars) }\end{array}$ \\
\hline $\begin{array}{l}\text { Buildings/Community Systems } \\
\text { Buildings System } \\
\text { Appliance Standards } \\
\text { Community Systems } \\
\text { Urban Waste } \\
\text { Technology and Consumer Products } \\
\text { Analysis and Technology Transfer } \\
\text { Residential Conservation Service } \\
\text { FEMP } \\
\text { Small Business }\end{array}$ & $\begin{array}{r}20271 \\
5619 \\
5152 \\
6264 \\
4401 \\
6343 \\
2711 \\
4453 \\
643\end{array}$ & 55857 \\
\hline $\begin{array}{l}\text { Transportation } \\
\text { Vehicle Propulsion RD\&D } \\
\text { Electric Vehicle RD\&D } \\
\text { Transportation System Utilization } \\
\text { Alternative Fuels Utilization }\end{array}$ & $\begin{array}{r}13681 \\
3940 \\
4495 \\
17958\end{array}$ & 40074 \\
\hline $\begin{array}{l}\text { Industrial } \\
\text { Waste Energy Reduction } \\
\text { Industrial Cogeneration } \\
\text { Industrial Process Efficiency } \\
\text { Implementation and Deployment }\end{array}$ & $\begin{array}{r}5299 \\
6243 \\
3253 \\
3\end{array}$ & 14798 \\
\hline $\begin{array}{l}\text { State and Local } \\
\text { Schools and Hospitals } \\
\text { Local Government Buildings } \\
\text { Weatherization Assistance } \\
\text { EMPA }\end{array}$ & $\begin{array}{r}6 \\
0.1 \\
409 \\
56\end{array}$ & 471 \\
\hline $\begin{array}{l}\text { Appropriate Technolgy } \\
\text { Small-Scale Technology }\end{array}$ & 4554 & 4554 \\
\hline
\end{tabular}



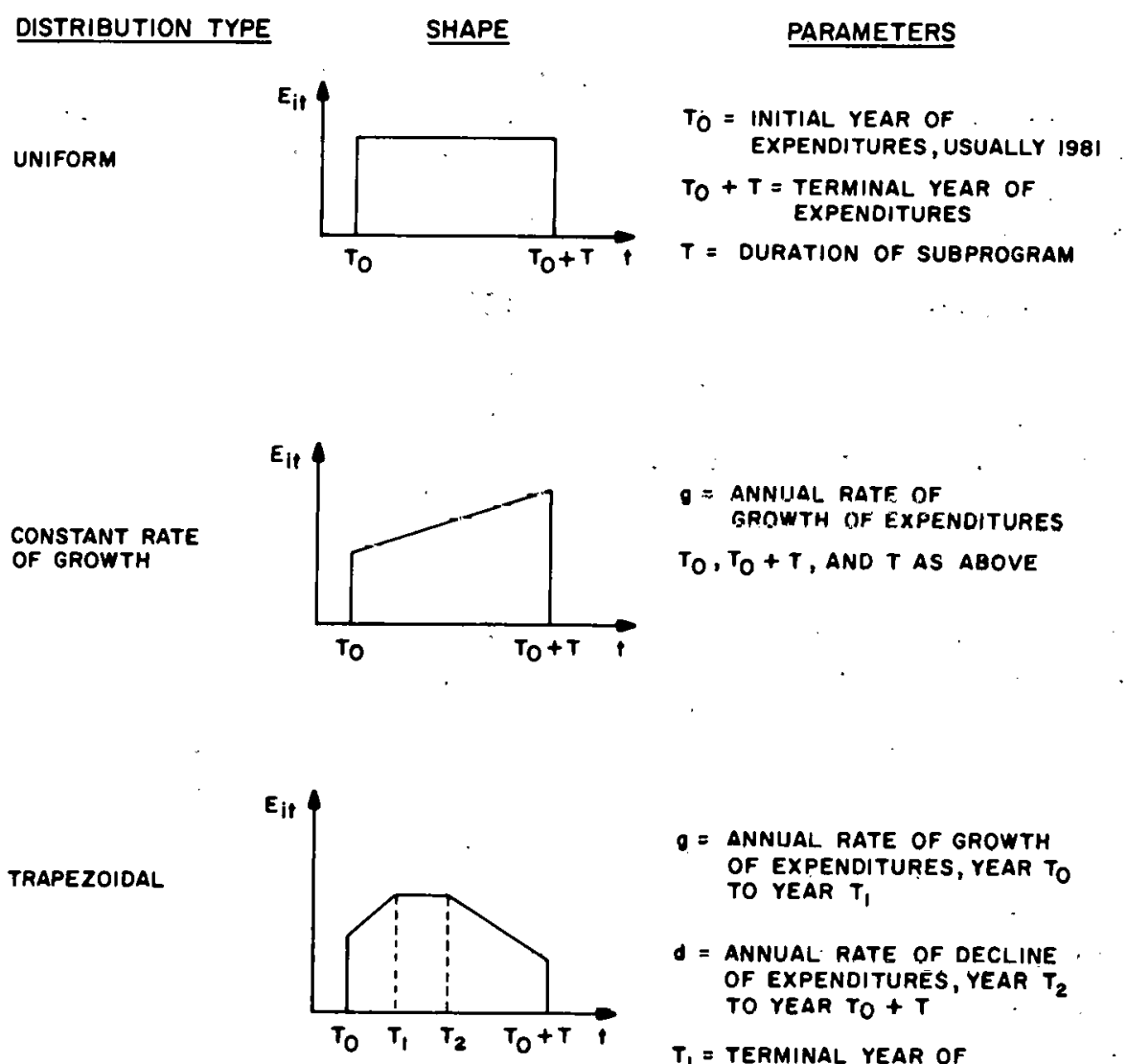
$\theta=$ ANNUAL RATE OF GROWTH OF EXPENDITURES, YEAR TO TO YEAR $T_{1}$
d = ANNUAL RATE OF DECLINE OF EXPENDITURES, YEAR $T_{2}$ TO YEAR TO + T
$T_{1}=$ TERMINAL YEAR OF EXPENDITURE GROWTH
$T_{2}=$ TERMINAL YEAR OF CONSTANT ANNUAL EXPENDITURE
$T_{0}, T_{O}+T$, AND T AS ABOVE

Figure 4.1. . Types of Distribution Mechanisms for Determining Annual Undiscourited Expenditures $\left(E_{i t}\right)$ from Total Discomted Costs 
and, hence, the uniform distribution conforms closely to the public outlay pattern reported in the CSA documentation. The subprograms to which the uniform distribution was applied and their durations are enumerated in Table 4.2.

\begin{tabular}{lc}
\hline & $\begin{array}{c}\text { Table } 4.2 \\
\text { Subprograms }\end{array}$ \\
\hline \multicolumn{1}{c}{ Subprogram } & $\begin{array}{c}\text { With Uniform Distributions of Cost: } \\
\text { Conservation Policy }\end{array}$ \\
\hline $\begin{array}{l}\text { Implementation and Deployment } \\
\text { Schools and Hospitals }\end{array}$ & $\begin{array}{c}\text { Duration of expenditures } \\
\text { (years) }\end{array}$ \\
Local Government Buildings & 1 \\
Weatherization Assistance & 2 \\
EMPA & 1 \\
\hline
\end{tabular}

- In subprograms where initial RD\&D costs are followed by costs that grow in proportion to annual energy savings, a constant rate of growth distribution is the appropriate rule. These-subprograms are characterized by initial outlays that lead, relatively quickly, to commercially successful end-use technologies promoting energy efficiency or fuel switching. From this, additional energy savings are obtained only by increasing the penerations and, consequently, the purchases of these products. Examples of these subprograms include Appliance Standards, Technology and Consumer Products, and Alternative Fuel Utilization. The growth parameters for these distributions are determined from the growth of energy savings over the period 1980-2000 with an allowance for economies of scale, i.e., the diminution of cost per million Btu, resulting from increased market penetrations. The annualization parameters for this distribution scheme are presented, by subprogram, in Table 4.3.

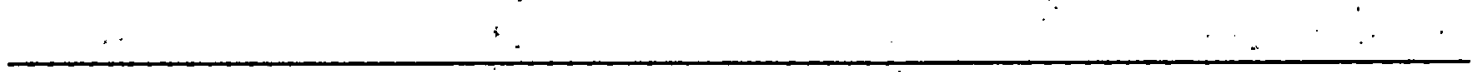

Table 4.3

Subprograms With Constant Growth Distributions of Cost: conservation Policy

\begin{tabular}{lcc}
\hline Subprogram & $\begin{array}{c}\text { Annual expenditures } \\
\text { growth rate } \\
\text { (percent) }\end{array}$ & $\begin{array}{c}\text { Duration } \\
\text { expenditures } \\
\text { (years) }\end{array}$ \\
\hline Appliance Standards & 4 & 20 \\
Technology and Consumer Products & 6 & 20 \\
Vehicle Propul sion RD\&D & 21 & 20 \\
Transportation System Utilization & 10 & 20 \\
Alternative Fuels Utilization & 15 & 20 \\
\hline
\end{tabular}


The trapezoidal distribution is selected for subprograms that initially require increasing RD\&D expenditures which level off for some length of time as the product or service provided by the program increases its penetration or effectiveness, or nears commercialization. Following these periods, unit costs decrease because of increased market penetration and information diffusion. In essence, this distribution mechanism is applicable to subprograms for which the most likely expenditure pattern is concentrated toward the earlier years. Thus, the realization of the direct net benefits that accompany increased market penetration in the longer $r$ un is conditional on the incurrence of direct net costs for the nearer term. The parameters used to develop the expenditures schedule for the trapezoidal scheme are shown, again by subprogram, in Table 4.4

Table 4.4

Subprograms With Trapezoidal Distributions of Cost: Conservation Policy

\begin{tabular}{|c|c|c|c|c|c|}
\hline \multirow{2}{*}{ Sub program } & \multicolumn{3}{|c|}{ Duration of expenditures } & \multicolumn{2}{|c|}{$\frac{\text { Annual rate of change }}{\text { (percent) }}$} \\
\hline & $\begin{array}{l}\text { Growth } \\
\text { period }\end{array}$ & $\begin{array}{l}\text { Uni form } \\
\text { period }\end{array}$ & $\begin{array}{l}\text { Decline } \\
\text { period }\end{array}$ & $\begin{array}{l}\text { Growth } \\
\text { period }\end{array}$ & $\begin{array}{l}\text { Decline } \\
\text { period }\end{array}$ \\
\hline Buildings Systems & 5 & 5 & 10 & 20 & $\cdot 10$ \\
\hline Community Systems & 5 & 5 & 10 & 20 & 10 \\
\hline $\begin{array}{l}\text { Urban Waste } \\
\text { Analysis and Technology }\end{array}$ & 5 & 5 & 10 & 20 & 10 \\
\hline $\begin{array}{l}\text { Transfer } \\
\text { Residential Conservation }\end{array}$ & 5 & 5 & 10 & 20 & 10 \\
\hline Service & 5 & 5 & 10 & 20 & 10 \\
\hline FEMP & 5 & 5 & 10 & 20 & 10 \\
\hline Small Business & 5 & 5 & 10 & 20 & 10 \\
\hline Electric Vehicle RD\&D & 5 & 2 & 13 & 20 & 10 \\
\hline Waste Energy Reduction & 5 & 2 & 13 & 20 & 10 \\
\hline $\begin{array}{l}\text { Industrial Cogeneration } \\
\text { Industrial Process }\end{array}$ & 5 & 2 & 13 & 20 & 10 \\
\hline Efficiency & 3 & 2 & 13 & 20 & 10 \\
\hline Small-Scale Technology & 5 & 5 & 10 & 20 & 20 \\
\hline
\end{tabular}

The annual expenditures associated with each subprugian next are divided into investment and labor services purchses in accordance with the type of expenditure implied by the success of that subprngram. For examplc, the cumuersial auccesese of the Vehicle Propulsion RD\&D and Alternative Fuels Utilization subprograms imply that incremental conservation expenditures are directed toward purchases from industries not unlike motor vehicles and petroleum refining, respectively. Similarly, efficiency improvements inducéd by the Appliance Standards and Technology 
and Consumer Products subprograms result in 1ncremental purchases, in part, from the household appliances industry. Thus, the allocation between investment and labor is determined from the corresponding expenditure shares of the total sectoral output most closely resembling the purchases implied for a successful CSA program. The information for this allocation is provided by The Input-Output Structure of the U.S. Economy, 1972, as reported in the February, 1979, Survey of Current Business. 11 The input-output sectors used for these calculations, with their investment and labor shares, are enumerated in Table 4.5. Table 4.6 displays the investment and labor shares associated with each subprogram.

\section{Table 4.5}

Sectors Used in Determining Investment/Labor Services Allocations:

Conservation Policy

\begin{tabular}{|c|c|c|c|c|}
\hline $\begin{array}{l}\mathrm{I}-0 \text { sector } \\
\text { number* }\end{array}$ & Industry name & Investment & share** & $\begin{array}{l}\text { Labor services } \\
\text { share }\end{array}$ \\
\hline 11 & New construction & .412 & & .588 \\
\hline 12 & MaIntenance construction & .287 & & .713 \\
\hline 31 & $\begin{array}{l}\text { Petroleum refining and } \\
\text { related industries }\end{array}$ & .155 & & .845 \\
\hline 40 & $\begin{array}{l}\text { Heating, plumbing, and } \\
\text { structural metal products }\end{array}$ & .230 & · & .770 \\
\hline 43 & Engines and turbines & .403 & & .597 \\
\hline 54 & Household appliances & .415 & & .585 \\
\hline 55 & $\begin{array}{l}\text { Electric lighting and } \\
\text { wiring equipment }\end{array}$ & .376 & & .624 \\
\hline 59 & $\begin{array}{l}\text { Motor vehicles and } \\
\text { equipment }\end{array}$ & .577 & 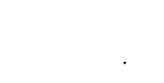 & .423 \\
\hline 68 & $\begin{array}{l}\text { Electric, gas, water } \\
\text { and sanitary services }\end{array}$ & .371 & & .629 \\
\hline
\end{tabular}

Source: Reference 11

* Refers to Input-Output Sector Numbers from the 1972 Standard Industrial Classification (SIC)

**Investment share 1 s the sum of the shares of producers' durable equipment expenditures ( $I-0$ Sectors $13,20,21-23,30,32,35-36$, and 39-63), property-type fincume, and indirece business taxes.

Several of the subprograms, most notably the grant policies and the Transportation System Utilization subprogram did not conform to the principle of the investment-labor sharing scheme above. In the case of grant-subprograms, expenditures were treated as purchases of only labor services. The transportation policy concentrates on education and information dissemination to promote a more energy-efficient utilization of the transportation system. As the success of this type of program ultimately affects labor-leisure decisions, these annual expenditures also were allocated fully to labor services. 


\begin{tabular}{|c|c|c|c|c|}
\hline \multicolumn{5}{|c|}{$\begin{array}{c}\text { Table } 4.6 \\
\text { Investment/Labor Services Allocation: } \\
\text { Conservation Policy }\end{array}$} \\
\hline Subprogram & $\begin{array}{l}\text { Sectors } \\
\text { determine }\end{array}$ & $\begin{array}{l}\text { used to } \\
\text { allocation* }\end{array}$ & $\begin{array}{l}\text { Investment } \\
\text { share }\end{array}$ & $\begin{array}{c}\text { Labor services } \\
\text { share }\end{array}$ \\
\hline Building Systems & Average & of 11,12 & .349 & .652 \\
\hline Appliance Standards & Average & of 40,54 & .323 & .677 \\
\hline Community Systems & & 68 & .371 & .629 \\
\hline $\begin{array}{l}\text { Urban Waste } \\
\text { Technology and Consumer }\end{array}$ & & 68 & .371 & .629 \\
\hline Products & Average & of 54,55 & .396 & .604 \\
\hline $\begin{array}{l}\text { Analysis and Technology } \\
\text { Transfer } \\
\text { Residential Conservatiol }\end{array}$ & on & of 11,12 & .349 & .651 \\
\hline Service & Average & of 11,12 & .349 & .651 \\
\hline FEMP & Average & of 11,12 & .349 & .651 \\
\hline Small Business & Average & of 11,12 & .349 & .651 \\
\hline $\begin{array}{l}\text { Vehicle Propulsion } \\
\text { RD\&D }\end{array}$ & & 59 & .577 & .423 \\
\hline $\begin{array}{l}\text { Electric Vehicle RD\&D } \\
\text { Transportation System }\end{array}$ & & 59 & .577 & .423 \\
\hline $\begin{array}{l}\text { Utilization } \\
\text { Alternative Fuels }\end{array}$ & & & 0 & 1.0 \\
\hline Utilization & & 31 & .155 & .845 \\
\hline $\begin{array}{l}\text { Waste Energy Reduction } \\
\text { Industrial }\end{array}$ & Average & of 40,43 & .316 & .684 \\
\hline Cogeneration & Average & of 40,43 & .316 & .684 \\
\hline Implementation and & & & & \\
\hline Deployment & & & 0 & 1.0 \\
\hline Schools and Hospltals & & & 0 & 1.0 \\
\hline Local Government Buildi & Lngs & & 0 & 1.0 \\
\hline Weatherization & & 12 & .287 & .713 \\
\hline EMPA & & & 0 & 1.0 \\
\hline Smal1-scale Technology & & 11 & .412 & .588 \\
\hline
\end{tabular}

*Sector numbers refer to sectors 11 sted in Table 4.5

Finally, the stream of annual investment expendftures for each sub= program is converted linto a capital scrvicco series that reflects the permanency of the services avallable from the undepreciated capital stock. These investment purchases represent gross annual additions to the capital stinck. Given a 15.0 percent pretax rate of return on the capital stock in place, the flow of capital services from a out dullar addicion to this stock is $\$ 0.15$. Thus, the conversion formula appears as

$$
\mathrm{CS}_{1 \mathrm{t}}=0.15 * \sum_{\mathrm{u}=0}^{t} \mathrm{I}_{1, \mathrm{t}-\mathrm{u}} *(1-\mathrm{d})^{\mathrm{u}} \text {, }
$$


where,

$$
\begin{aligned}
\mathrm{CS}_{\mathbf{i t}}= & \text { the capital services' claims of subprogram } i \text { in year } t, \\
\mathbf{T}_{\mathbf{i}, t-u}= & \text { the investment expenditures associated with } \\
& \text { subprogram } i \text { in the year } t-u, \\
\mathrm{~d}= & \text { the depreciation rate (taken to be } 8.0 \text { percent), } \\
u= & \text { a time index }(0=\text { year } t, 1=\text { year } t-1, \ldots) .
\end{aligned}
$$

\begin{tabular}{|c|c|c|c|c|}
\hline $\begin{array}{r}\text { Annual } \\
\text { Bui }\end{array}$ & $\begin{array}{l}\text { Costs } \\
\text { 1dings/ } \\
\text { Conser }\end{array}$ & $\begin{array}{c}4.7 \\
\text { Energy } \\
\text { nunity } \\
\text { ion Pol }\end{array}$ & $\begin{array}{l}\text { Savings: } \\
\text { ystems } \\
\text { cy }\end{array}$ & \\
\hline Ann & $\begin{array}{l}\text { ual resc } \\
\text { billions }\end{array}$ & $\begin{array}{l}\text { ce clai } \\
\text { f } 1972\end{array}$ & $\begin{array}{l}s(\operatorname{costs}) \\
\text { ollars) }\end{array}$ & $\begin{array}{l}\text { Energy savings } \\
\text { (quadrillion Btu) }\end{array}$ \\
\hline Subprogram & Capital & Labor & Total & Total \\
\hline 1990 & & & & \\
\hline Buildings System & 0.9 & 1.9 & 2.9 & 2.0 \\
\hline Appliance Standards & 0.2 & 0.4 & 0.6 & 0.9 \\
\hline Community Systems & 0.3 & 0.5 & 0.7 & 0.4 \\
\hline $\begin{array}{l}\text { Urban Waste } \\
\text { Technology and Consumer }\end{array}$ & 0.3 & 1.6 & 0.9 & 0.4 \\
\hline $\begin{array}{l}\text { Products } \\
\text { Analysis and Technology }\end{array}$ & 0.2 & 0.3 & 0.5 & 0.5 \\
\hline $\begin{array}{l}\text { Transfer } \\
\text { Residential Conservation }\end{array}$ & 0.3 & 0.6 & 0.9 & 0.7 \\
\hline Service & 0.1 & 0.3 & 0.4 & 0.2 \\
\hline FEMP & 0.2 & 0.4 & 0.6 & 0.4 \\
\hline $\begin{array}{l}\text { Small Business } \\
\text { Total* }\end{array}$ & $\frac{* *}{2.5}$ & $\frac{0.1}{5.1}$ & $\frac{0.1}{7.6}$ & $\frac{0.1}{5.6}$ \\
\hline 2000 & & & & \\
\hline Buildings Systems & 1.1 & 0.7 & 1.8 & 3.9 \\
\hline Appliance Standards & 0.4 & 0.6 & 1.0 & 1.4 \\
\hline Community Systems & 0.3 & 0.2 & 0.5 & 1.0 \\
\hline $\begin{array}{l}\text { Urban Waste } \\
\text { Technology and Consumer }\end{array}$ & 0.4 & 0.2 & 0.6 & 1.3 \\
\hline Products & 0.4 & 0.6 & 1.0 & 0.7 \\
\hline $\begin{array}{l}\text { Analysis and Technology } \\
\text { Transfer } \\
\text { Residential Conservation }\end{array}$ & 0.3 & 0.2 & 0.6 & 0.9 \\
\hline Service & 0.1 & 0.1 & 0.2 & 0.3 \\
\hline FEMP & 0.2 & 0.2 & 0.4 & 0.4 \\
\hline Small Business & $* *$ & $* *$ & 0.1 & 0.1 \\
\hline Total* & $\overline{3.2}$ & $\overline{2.9}$ & $\overline{6.1}$ & $\overline{10.0}$ \\
\hline
\end{tabular}

*Totals may not add because of rounding.

$* *$ Less than 0.05 billion dollars. 
The resulting series for capital and labor services represent the annual resource claims, $1 . e .$, the direct pollcy costs, assoclated with the annual energy savings provided by each of the CSA inttiatives. For the years 1990 and 2000, summaries of the costs and energy savings are provided, by subprogram, in Tables 4.7 through 4.10 and, by major program area, In Table 4.11 .

Table 4.8

Annual Costs and Energy Savings: Transportation: Conservation Pollcy

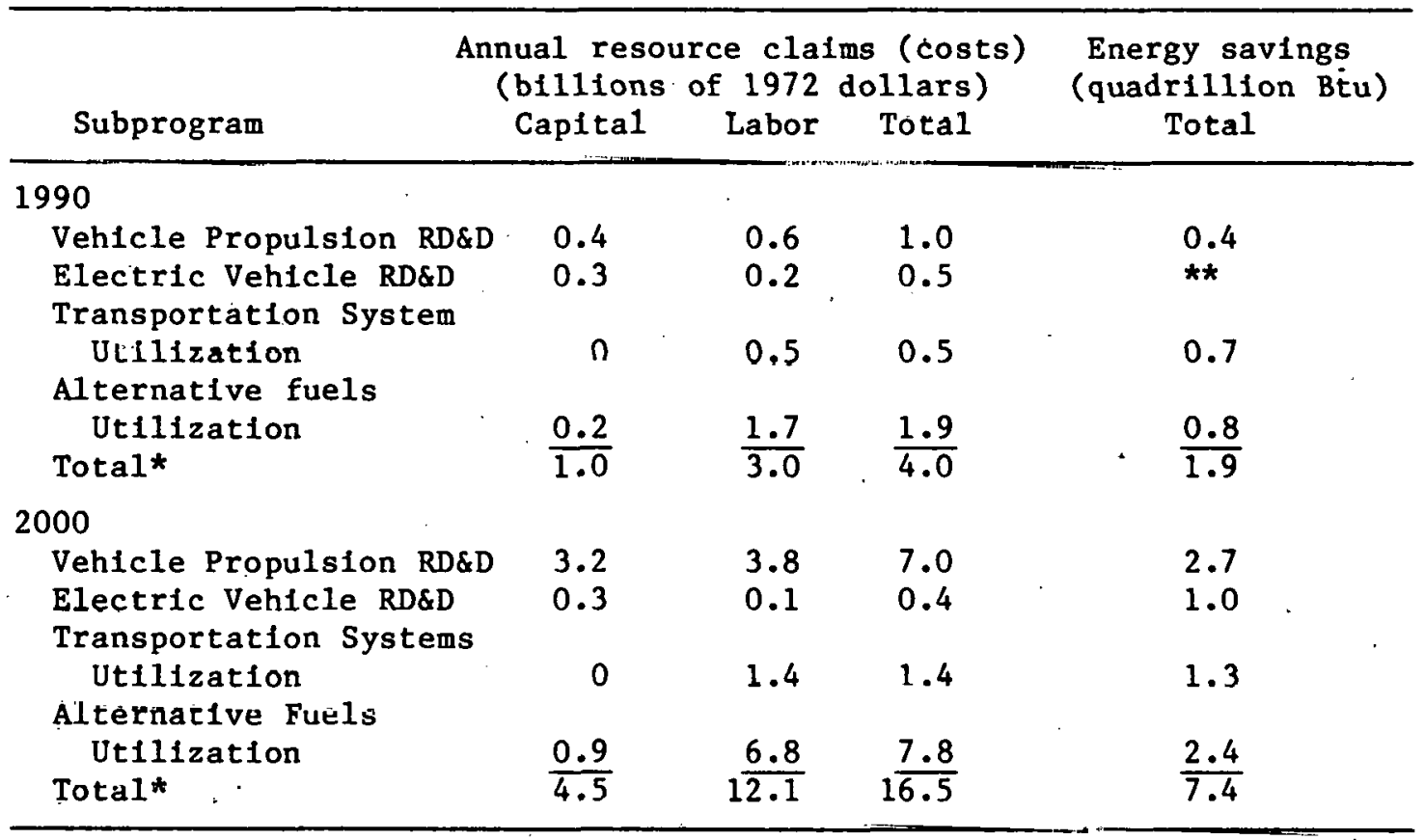

*Totals may not add because of round1ng. .

**Less than 0.05 quads.

The conservation policy is introduced into the reference profection from the BNL/DJA model system in two stages. The first establishes the initial conditions for the projection by accounting for reductions in energy use, releases of real resources originally devuled to energy production in absence of conservation, and claims on total avallable resources associated with conservation activities. In the second stage, the model system is iterated as usual.

In the BNL energy model, conservation is represented as a new source of the delivered energy required to satisfy particular end uses, e.g., space heat, process heat, motive power, etc. Conservation in the CSA documentation is specified as primary energy savings in the residential, commercial; industrial, and transportation sectors. The primary energy savings in each program area are allocated to specific end uses in accordance with the relative importance of the end use in the consuming sector 


\begin{tabular}{|c|c|c|c|c|c|}
\hline Annual Costs & $\begin{array}{r}\text { Ta } \\
\text { and Ene } \\
\text { Conserv }\end{array}$ & $\begin{array}{l}\text { ble } 4.9 \\
\text { rgy Savin } \\
\text { ation Pol }\end{array}$ & $\begin{array}{l}\text { ics: } \\
\text { licy }\end{array}$ & rial: & \\
\hline Subprogram & $\begin{array}{l}\text { ual reso } \\
\text { bilitions } \\
\text { Capital }\end{array}$ & $\begin{array}{l}\text { urce clat } \\
\text { of } 1972 \\
\text { Labor }\end{array}$ & $\begin{array}{l}\text { ims (costs) } \\
\text { dollars) } \\
\text { Total }\end{array}$ & $\begin{array}{c}\text { Energy saving } \\
\text { (quadrillion } B \\
\text { Total }\end{array}$ & $\begin{array}{ll}\text { gs } \\
\text { Btu) }\end{array}$ \\
\hline 1990 & & & & & \\
\hline $\begin{array}{l}\text { Waste Energy Reduction } \\
\text { Industrial Cogeneration } \\
\text { Industrial Process }\end{array}$ & $\begin{array}{l}0.2 \\
0.3\end{array}$ & $\begin{array}{l}0.5 \\
0.6\end{array}$ & $\begin{array}{l}0.7 \\
0.8\end{array}$ & $\begin{array}{l}1.2 \\
0.5\end{array}$ & \\
\hline $\begin{array}{l}\text { Efficlency } \\
\text { Implementation and }\end{array}$ & 0.1 & 0.3 & 0.4 & 0.9 & \\
\hline $\begin{array}{l}\text { Deployment } \\
\text { Total* }\end{array}$ & $\frac{0}{1.0}$ & $\frac{0}{3.0}$ & $\frac{0}{4.0}$ & $\frac{0}{1.9}$ & \\
\hline 2000 & & & & & \\
\hline $\begin{array}{l}\text { Waste Energy Reduction } \\
\text { Industrial Cogeneration } \\
\text { Industrial Process }\end{array}$ & $\begin{array}{l}0.2 \\
0.3\end{array}$ & $\begin{array}{l}0.2 \\
0.2\end{array}$ & $\begin{array}{l}0.4 \\
0.5\end{array}$ & $\begin{array}{l}1.8 \\
0.8\end{array}$ & \\
\hline $\begin{array}{l}\text { Efficiency } \\
\text { Implementation and }\end{array}$ & 0.1 & 0.1 & 0.2 & 1.6 & \\
\hline $\begin{array}{l}\text { Deployment } \\
\text { Total* }\end{array}$ & $\frac{0}{0.6}$ & $\frac{0}{0.5}$ & $\frac{0}{1.1}$ & $\frac{0}{4.2}$ & \\
\hline
\end{tabular}

*Totals may not add because of rounding.

to which the conservation subprograms are directed. Then, for each end use, the delivered energy inputs in the reference projection are converted to their primary energy equivalents, and an average conversion efficlency (delivered Btu per Btu of primary energy) is determined. This, when multiplied by the primary energy savings in each end-use category, determines the delivered energy savings resulting from conservation activities. For each end-use demand, a constraint. is introduced into the energy model. These restrict total delivered energy inputs to a particular end use to be no greater than the total from the reference projection less the delivered energy savings as determined above. The energy model then is solved. In the soluition, the excess of end-use demand over thesum of delivered energy inputs times their respective end-use device efficiences is the amount of conservation expressed as delivered energy equivalent. In subsequent iterations of the energy model the conservation amounts determined by this procedure are fixed and the constraints on total dellvered energy to each end use are removed. In this manner, the energy benefits from conservation policy are maintained in the solution in Isolation from other energy changes.

A comparison of the reference projection with the inftial solution from above provides information on the amount of refined petroleum, 
Table 4.10

Annual Costs and Energy Savings: State and Local, Appropriate Technology: Conservation Pollcy

\begin{tabular}{|c|c|c|c|c|}
\hline Subprogram & $\begin{array}{c}\text { Annual reso } \\
\text { (billions } \\
\text { Capital }\end{array}$ & $\begin{array}{l}\text { urce clai } \\
\text { of } 1972 \\
\text { Labor }\end{array}$ & $\begin{array}{l}\text { Ims (costs) } \\
\text { dollars) } \\
\text { Total }\end{array}$ & $\begin{array}{c}\text { Energy savings } \\
\text { (quadrillion Btu) } \\
\text { Total }\end{array}$ \\
\hline \multicolumn{5}{|l|}{$\begin{array}{l}\text { State and Local: } \\
1990\end{array}$} \\
\hline $\begin{array}{l}\text { Schools and Hospitals } \\
\text { Local Government }\end{array}$ & 0 & 0 & 0 & 0 \\
\hline buildings & 0 & 0 & 0 & 0 \\
\hline Weatherization & 12 & 0 & 0 & 0.005 \\
\hline EMPA & 0 & 0 & 0 & 0 \\
\hline Total & $\overline{12}$ & $\overline{0}$ & $\overline{0}$ & $\overline{0.005}$ \\
\hline \multicolumn{5}{|l|}{2000} \\
\hline $\begin{array}{l}\text { Schools and Hospitals } \\
\text { Local Government }\end{array}$ & 0 & 0 & 0 & 0 \\
\hline Bufldings & 0 & 0 & 0 & 0 \\
\hline Weatherization & 5 & 0 & 5 & 0.005 \\
\hline EMPA & 0 & 0 & 0 & 0 \\
\hline Total & $\overline{5}$ & $\overline{0}$ & $\overline{5}$ & $\overline{0.005}$ \\
\hline \multicolumn{5}{|l|}{$\begin{array}{l}\text { Appropriate Technology: } \\
1990\end{array}$} \\
\hline Sma11-Scale Technology & 246 & 392 & 638 & 0.250 \\
\hline 2000 & & & & \\
\hline Small-Scale Technology & 283 & 152 & 435 & 0.630 \\
\hline
\end{tabular}

natural gas, and electricity that are displaced as a result of conservation policy. When valued at their respective prices, these displacenents represent the direct economic benefits of energy conservation against which the direct policy costs are measured. The new energy solution is Incorporated into the DJA economic model sequentially with the net direct claims on capital and labor services. The net direct claims are determined as the differences between capital and labor claims induced by the conservation policy and those resources released through energy dieplacements.

From this point, the usual solution process for the combined model systems is followed. The economic solution contains information on the new level and pattern of production and spendlug throughout the economy. Adjustments to the level and structure of energy service demands are determined by accounting for energy changes due to changes in the level and structure of economic activity and the substitution of nonenergy inputs into production and consumption. The resultant vector of end-use demands is inserted into the energy model, producing a new configuration of the energy system. The solution valnes of energy prices and quantities, energy imports, and the output levels and input structures for new energy technologies are entered into the economic model. This 1terative procedure continues until consistency between the energy and economic system in the two models is achieved. 


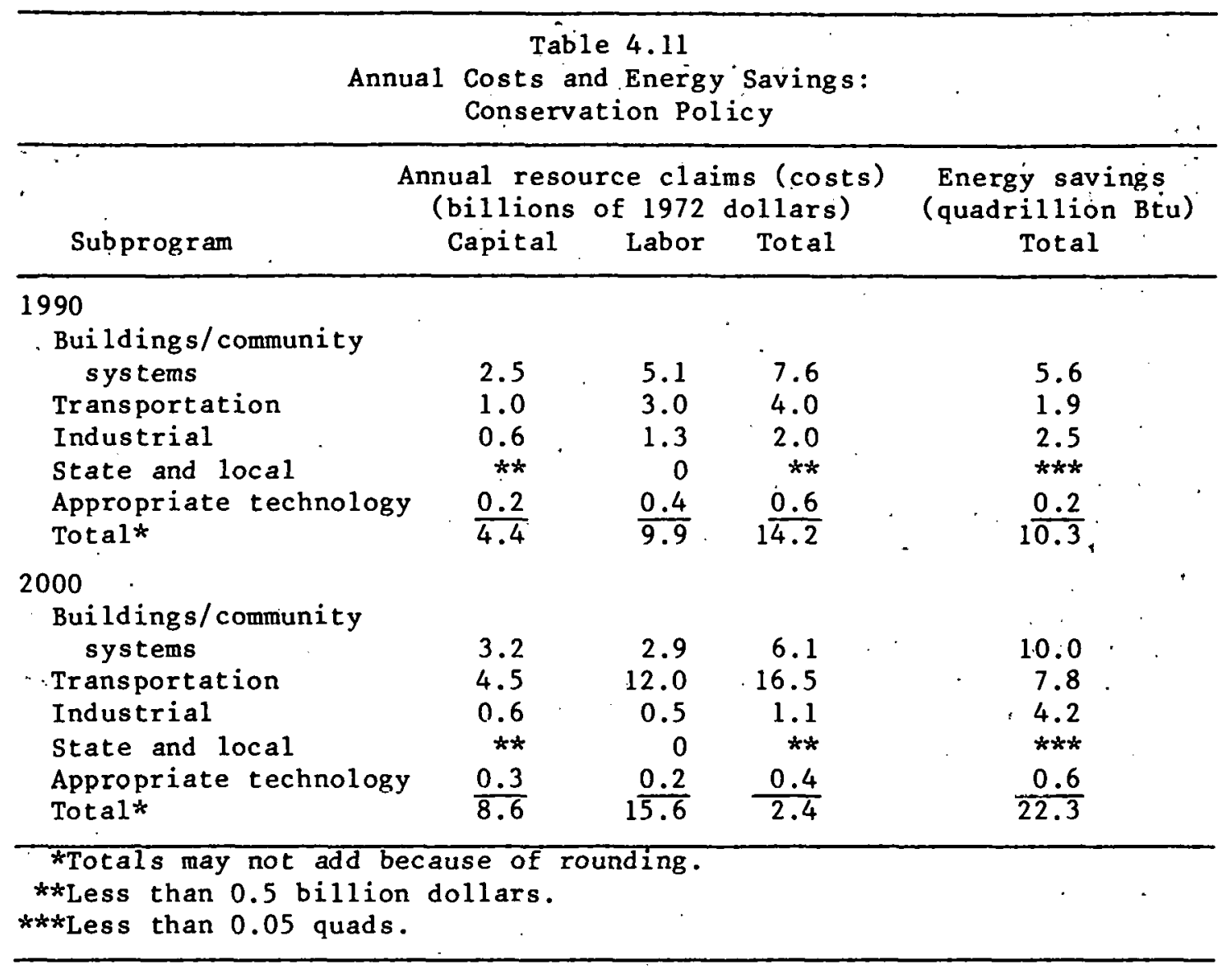

4.3 The Conservation Policy: Energy, Economy, and Environmental Interactions

4.3.1 Introduction. In this section, the results of the BNL/DJA conservation analysis are presented. The subsequent discussions describe the influences of conservation policy on the growth and structure of the U.S. economy, the pattern of development of the nation's energy system, and the environemental implications of this energy transition.

4.3.2 Economic Structure and Growth Under the Conservation Policy. The period from 1980 to 2000 is projected to be one of continuing economic growth. Over the last decade of the century, the conservation policy stimulates this growth, slightly pivoting around the 1990 trend in growth rates present in the reference case. With these programs, the rate of increase in real GNP diminishes over time from 3.0 percent per year between 1980 and 1990 to approximately 2.7 percent annually until 2000. As the various programs become increasingly effective, the resulting decline in energy requirements frees resources, in particular, the capital and labor formerly required for the production of energy. To 1990 , the resources released do not compensate for the additional capital and labor services required for conservation activities. Given the strictly limited availabilities of these resources, this net withdrawal 
from other productive uses imposes a small cost, $\$ 2.2$ billion $\$(1972)$, on the economy in terms of income and production foregone. But, by the year 2000 , the resource claims by the conservation measures are surpassed by the resources released from conventional energy production. These extra resources are redirected to other uses, including increased final spending. This implies additional economic growth relative to the reference projection. Real GNP per capital in 1972 dollars rises from a level of $\$ 6400$ in 1980 at an average annual rate of about 2 percent, reaching $\$ 9500$ by the year 2000 :

This economic growth can also be expressed in terms of increased labor input and advances in gross labor productivity. Table 4.12 shows the principal labor, output, and productivity variables. As in the reference projection, labor force expansion slows during these twenty years. But, there is a positive influence on the rate of productivity advance from the conservation policy. The addition to this factor provides the portion of increased real growth not attributable to increases in employment. Productivity is projected to increase at an annual rate that rises from 1.5 percent in the 1980 's to 1.6 percent through 2000 . This growth includes the effects of increases in labor efficiency, capical efflclency, and changes in the sectoral mix of production. Also important in improving labor productivity, relative to the reference case, is the amount of capital per worker, which experiences larger increases during these two decades because of the conservation policy.

Table 4.12

Labor, Output, and Productivity: Conocrvation Case

\begin{tabular}{|c|c|c|c|c|c|}
\hline & 1980 & 1990 & 2000 & $\begin{array}{l}\text { Averag } \\
\text { growth } \\
1980- \\
1990\end{array}$ & $\begin{array}{l}\text { annual } \\
\text { rates } \\
1990- \\
2000\end{array}$ \\
\hline 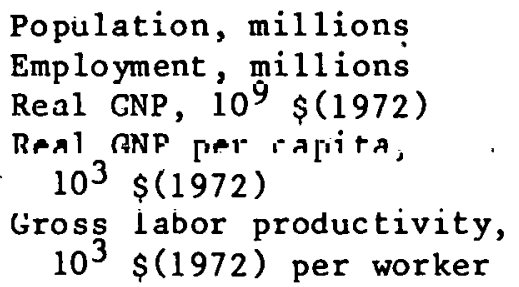 & $\begin{array}{r}222.2 \\
97.8 \\
1417.1 \\
6.378\end{array}$ & $\begin{array}{r}243.5 \\
112.5 \\
1899.1 \\
7.799\end{array}$ & $\begin{array}{r}260.4 \\
124.5 \\
2473.7\end{array}$ & $\begin{array}{l}0.92 \\
1.41 \\
2.97\end{array}$ & $\begin{array}{l}0.67 \\
1.02 \\
2.68 \\
1.99\end{array}$ \\
\hline
\end{tabular}


The volume of expenditure grows in accordance with the sustained. increases in the quantity of production. In Table 4.13, these expenditures are divided into purchases by consumers, investors, government, and the rest of the world. All except net foreign purchases share in the growth in total expenditure. Consumption becomes increasingly more important as its portion of real GNP rises over time. Investment's share is stable at around 15.0 percent, its absolute level increasing with the total volume of expenditure. As with the other projections, the aggregate patterns of purchases change only gradually, with consumption showing a slight increase in relative importance.

Table 4.13

Economic Output and Expenditure:

Conservation Case

\begin{tabular}{lrrr}
\hline & 1980 & \multicolumn{1}{c}{1990} & \multicolumn{1}{c}{2000} \\
\hline Real GNP components, \$(1972) billion & & & \\
$\quad$ Consumption & 906.1 & 1233.2 & 1607.7 \\
Investment & 213.6 & 283.6 & 370.3 \\
Government* & 274.9 & 373.0 & 491.5 \\
Net exports & 22.4 & 9.4 & 4.2 \\
GNP**. & 1417.1 & 1899.1 & 2473.7 \\
Composition of real GNP, percent & & & \\
Consumption & 63.9 & 64.9 & 65.0 \\
Investment & 15.1 & 14.9 & 15.0 \\
Government & 19.4 & 19.6 & 19.9 \\
GNP** & 100.0 & 100.0 & 100.0 \\
\hline
\end{tabular}

*Government purchases of goods and services; transfer expenditures are not included.

* Totals may not add because of rounding.

The sectoral mixture of what is produced indicates a more substantial restructuring of the economy. Projected changes in the pattern of final spending are given in Table 4.14. The trends, evident in the reference projection, are also apparent under the conservation policy. However, they are accentuated as conservation permits a reallocation of expenditures away from energy and toward nonenergy goods and services. The changing patterns of expenditure result from the dramatic reduction in the growth of energy purchases over the period 1980-2000. In fact, unlike the reference case, there is actually a decline in energy's share of final spending to 1990. The expenditure dollars released by conservation tend, on average, to be redirected to the outputs of the manufacturing and trade and services sectors. To 1990 and relative to the reference projection, the rate of decline in manufacturing's share of total spending is less, whereas the rate of increase in the shares of other nonenergy sectors are larger. After 1990, there is a continued 
redirection of expenditures away from energy and, thus, another accentuation of the reference case trends. The overall decline in the relative importance of energy occurs as that economizing experienced in the reference projection is augmented by the nonprice energy conservation provided by these initiatives.

Table 4.14.

Aggregate Final Demand Expenditures:

Conservation Case

\begin{tabular}{lrrr}
\hline & 1980 & \multicolumn{1}{c}{1990} & \multicolumn{1}{c}{2000} \\
\hline Composition of purchases, percent & & & \\
Agriculture, nonfuel mining, & & & \\
$\quad$ construction & 5.60 & 8.68 & 8.05 \\
Manufacturing & 34.64 & 26.29 & 26.76 \\
Transportation & 3.26 & 3.32 & 3.78 \\
Services & 53.27 & 58.71 & 59.10 \\
Energy & 3.23 & 3.00 & 2.31 \\
\hline
\end{tabular}

The influence of the conservation programs also is evidenced by the adjustments in the composition of inputs to production. The time pattern of input coefficients (capital, labor, energy, and intermediate materials) for aggregate output is presented in Table 4.15. The major trends show an increase in the relative importance of capital, accompanied by a decline in that of labor and energy. The attainment of the energy savings from conservation necessitates a withdrawal of capital and 1 abor services from other productive uses within the economy. Simultaneously, conservation permits the release of those resources originally devoted to

Table 4.15

Aggregate Economic Input Patterns:

Share Coefficients for Aggregate Output: Conservation Case

\begin{tabular}{lccc}
\hline \multicolumn{1}{r}{ Input Coefficient } & 1980 & 1990 & 2000 \\
\hline Capital & .1515 & .1794 & .2041 \\
Labor & .2273 & .2072 & .1815 \\
Energy & .0314 & .0272 & .0267 \\
Mateitials & .9908 & .5862 & .5876 \\
\hline
\end{tabular}

energy production. Finally, the new level and structure of final spending under the conservation policy requires a reconfiguration of input patterns. With the supply and demand balance conditions in each factor market, these combine to influence the relative price structure for in- 
puts into production which, in turn, further affects the pattern of input choices. The effects of these changes are to accelerate the adjustments evidenced for the reference projection. Conservation succeeds in reducing dramatically the energy intensity of aggregate output and in motivating additional subsitutions for labor. However, the additional economization of the labor input and the faster growth of capital per worker relative to the reference projection contribute materially to the larger rate of gross productivity advance over the final decade of the century. Conservation also improves the energy efficiency of capital as the energy-capital ratio experiences a larger decline than in the reference case. However, the rate of decline slows appreciably to the year 2000 suggesting that this efficiency improvement becomes increasingly difficult to achieve.

4.3.3 Energy System Development Under the Conservation Policy. Energy Service Demands. In the conservation case, the aggregate demand for energy services is projected to rise from 32.9 quadrillion Btu in 1980 to 43.4 quads by the year 1990. After 1990 energy services rise less rapidly as shown in Table 4.16, and grow at an average rate of 2.3 percent per year to reach 54.4 quads by 2000 .

\begin{tabular}{|c|c|c|}
\hline & $\begin{array}{r}\text { Table } \\
\text { The Level a } \\
\text { Total Energy } \\
\text { Conserva }\end{array}$ & \\
\hline Year & $\begin{array}{l}\text { Level of demand } \\
\text { (quadrillion Btu) }\end{array}$ & $\begin{array}{l}\text { Growth of demand } \\
\text { (percent per year) }\end{array}$ \\
\hline 1980 & 43.9 & \\
\hline $\begin{array}{l}1990 \\
2000\end{array}$ & $\begin{array}{l}43.4 \\
54.4\end{array}$ & $\begin{array}{l}2.81 \\
2.29\end{array}$ \\
\hline
\end{tabular}

The composition of energy services by aggregate consuming sector is anticipated to change over the 1980-2000 period, with industrial demand accounting for an increasingly larger share of total service requirements. Industrial demand for energy services rises from 18 qyads in 1980 to 32 quads by 2000 , and accounts for the largest share of total energy service demand in all years. As shown in Table 4.17, the largest components of industrial energy services are process heating and petrochemicals. Process heating requirements are projected to rise less rapidly than total energy service demands over time and account for 28 percent of total energy services in 2000 , as compard to a 30 percent share in 1980. Petrochemicals demand rises from 4.8 quads to 8.9 quads over the 1980-2000 period, increasing its share from 15 to 17 percent of total demand for services by 2000 . 
Total 4.17

Energy Service Demands:

Conservation Case

(Quadrillion B Btu)*

\begin{tabular}{|c|c|c|c|}
\hline & 1980 & 1990 & 2000 \\
\hline $\begin{array}{l}\text { Residential/commercial } \\
\text { Space conditioning } \\
\text { Miscellaneous thermal } \\
\text { Miscellaneous electric } \\
\text { Subtotal }\end{array}$ & $\begin{array}{r}6.6 \\
1.9 \\
2.2 \\
10.7\end{array}$ & $\begin{array}{r}9.2 \\
2.2 \\
2.1 \\
13.5\end{array}$ & $\begin{array}{r}11.5 \\
2.0 \\
1.9 \\
15.4\end{array}$ \\
\hline $\begin{array}{l}\text { Industrial } \\
\text { Prutess heat. } \\
\text { Aluminum } \\
\text { Iron and Steel } \\
\text { Miscellaneous electric } \\
\text { Petrochemicals } \\
\text { Subtotal }\end{array}$ & $\begin{array}{l}0.6 \\
0.2 \\
0.6 \\
2.8 \\
4.8 \\
18.0\end{array}$ & $\begin{array}{r}12.4 \\
0.3 \\
0.8 \\
4.1 \\
6.5 \\
24: 1\end{array}$ & $\begin{array}{r}15.3 \\
0.4 \\
1.0 \\
6.0 \\
8.9 \\
31.6\end{array}$ \\
\hline $\begin{array}{l}\text { Transportation } \\
\text { Private ground transport } \\
\text { Truck, bus, rail and ship } \\
\text { Alr transport } \\
\text { Electric rail } \\
\text { Subtotal }\end{array}$ & $\begin{array}{l}2.0 \\
1.5 \\
0.7 \\
0.1 \\
4.2 \\
\end{array}$ & $\begin{array}{l}2.3 \\
1.7 \\
1.3 \\
0.1 \\
5.4 \\
\end{array}$ & $\begin{array}{l}2.7 \\
2.1 \\
1.7 \\
0.2 \\
6.7\end{array}$ \\
\hline Total energy service demand & 32.9 & 43.0 & 53.7 \\
\hline
\end{tabular}

*Totals may not add because of rounding.

Residential/commercial demands for services are projected to Increase at an average rate of 1.8 percent per year to 15.4 quads by 2000. Aggregate demand for space conditioning, water heating, and miscellaneous electric services account for 29 percent of total service demands in 2000. Within the residential/commercial consuming sector, the share of total services used to provide space, conditioning services (i.e., space heat and air conditioning) rises slighty over the 1980 to 1990 period, reflecting increased penetration of alr conditioning devices, and a constant share thereafter, due to saturation of the alr conditioning market in the post-1990 period.

Transportation services maintain the smallest share of total services in all years, and increasing prices for petroleum products result in a decrease in the aggregate transpertation share of total demand over time. Aggregate transportation services are projected to increase at an average annual rate of 2.4 percent and reach 6.7 quads in the year 2000 . The mix of transport services is expected to shift away from private ground transport toward greater use of alr transport and electric rafl over the projection period. 
Delivered Energy Prices and Quantities. The aggregate level of delivered energy is projected to remain relatively constant in the conservation case, ranging from 59 to 61 quadrillion Btu over the 1980-2000 period. The pattern of delivered energy among aggregate consuming sectors changes significantly over the projection period, as shown in Table 4.18. The absolute level of energy flows to the residential/commercial sector decreases monotonically over the projected period from 14.5 quads in 1980 to 10.6 quads by 200n. Transportation energy requirements decrease similarly from 20.8 to 15.8 quads during the period. A larger share of total delivered energy is used to provide industrial energy services over time. The total amount of energy delivered to the industrial sector is anticipated to increase by 34 percent over the projected period to 32 quads by 2000 , and account for 55 percent of total delivered energy consumption.

Table 4.18

Delivered Energy Quantities by Aggregate Economic Sector: Conservation Case (Quadrillion Btu)

\begin{tabular}{llll}
\hline & 1980 & 1990 & 2000 \\
\hline Residential/commercial & 14.5 & 14.0 & 10.6 \\
Industrial & 24.1 & 27.6 & 32.4 \\
Transportation & $\frac{20.8}{59.4}$ & $\frac{19.3}{60.9}$ & $\frac{15.8}{58.8}$ \\
Total* & & \\
\hline
\end{tabular}

*Totals may not add because of rounding.

The composition of fuels, heat, and electricity used to provide energy services shifts towards greater use of electricity and solid fuels as petroleum products are displaced in the energy system. Table 4.19 shows the mix of delivered energy by fuel type in the conservation case. Use of coal, coke, and wood for direct consumption rises from 6 quads in 1980 to 10 quads in 2000. Electricity use shows similar gains, rising from 8 to 14 quads during the next two decades. One of the major goals of the demand-oriented conservation strategy is the reduction of petroleum products consumed. In the conservation case, consumption of refined petroleum and methanol decreases from 31 quads in 1980 to approximately half that level, 16 quads, by the year 2000. Gas usage rises over the short term to substitute for reduced petroleum use, but returns to a level of 13 quads by 2000 , as the energy-using capital stock changes from fossil burning to more electric and direct heating equipment. Direct solar, geothermal, and waste heat contribute 5 quads of delivered energy by the year 2000. Some of the conservation programs analyzed actually supplied a fuel (Alternative Fuels Utilization) which was not captured as primary energy form in TESOM, but was included in the conservation component of delivered energy. 


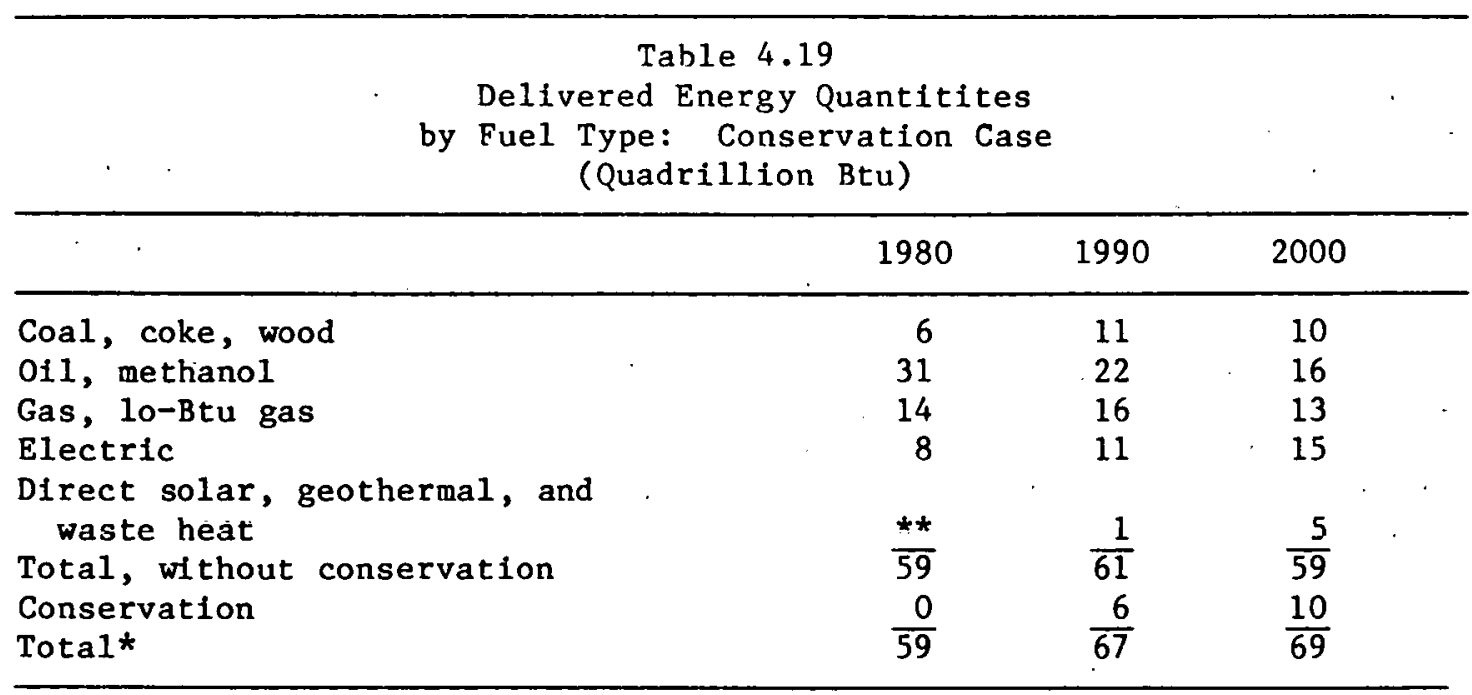

*Totals may not add because of rounding.

**Less than 0.5 quad.

The average prices of delivered fuels and electricity are given in Table 4.20 for the conservation case. During the 1980-1990 period, the average price of delivered energy is projected to increase at an average annual rate of 1.6 percent to 4.29 constant dollars of 1972 per million Btu in 1990. The major factors contributing to this increase are the assumed increases in the price of crude o1l, deregulation of natural gas prices, and an increased degree of electrification during the 1980-19.90 period. After 1990, the average dellvered energy price grows more slowly as direct heat substitutes for relatively more expensive petroleum products. In addition, electricity prices grow slower during the pust-1990 periud as more efficient generation technolngtes, including combined cycle and cogeneration, become available. The average delivered energy price increases from $\$ 4.29$ per mililion Btu in 1990 to $\$ 5.02$ by the year 2000 .

Prices of delivered ofl and gas products rise most rapidly durling the projection period. The price of refined petroleum products increases from $\$ 3.59$ to $\$ 5.48$ from 1980 to 2000 , which corresponds to an average rate of growth of 2.1 percent. Delivered gas prices rise at an average annual rate of 11.0 percent from 1980 to 1990 as the domestic natural gas price is deregulated, and at a more moderate rate of 2.6 percent from $\$ 3.88$ to $\$ 5.00$ by the year 2000. During the post-1990 period, delivered methanol becomes competitive in price with refined oll products and delivered 1o-Btu gas is competitive with refined natural gas products. Delivered coal prices rise at an average annual rate of 2.3 percent over the projected period. Wood prices are projected to rise less quickly than coal prices, but remain above coal prices in all years--at $\$ 1.78$ per million Btu In 1980 and $\$ 2.04$ in the year 2000 . 
Table 4.20

Delivered Energy Prices: Conservation Case (1975\$/Million Btu)

\begin{tabular}{lccc}
\hline & 1980 & 1990 & 2000 \\
\hline Delivered coal & 0.86 & 1.08 & 1.36 \\
Delivered coke & 1.94 & 2.12 & 2.21 \\
Delivered oil & 3.59 & 4.29 & 5.48 \\
Delivered gas & 1.36 & 3.88 & 5.00 \\
Delivered electricity & 9.63 & 10.56 & 11.21 \\
Direct solar \& geothermal & - & - & -- \\
Delivered waste heat & - & 4.33 & 4.33 \\
Delivered lo-Btu gas & -- & 1.44 & - \\
Delivered wood & - & 1.90 & 2.04 \\
Delivered methanol & 5.07 & 4.09 & 5.33 \\
Average delivered price & & & \\
\hline
\end{tabular}

Primary Energy Prices and Quantities. Aggregate primary energy consumption in the conservation case increases from 82 quads in 1980 to 87 quads. by 1990 and remains essentially constant thereafter. The composition of primary energy usage changes significantly over the projected period. The share of renewable resources more than doubles, from 7 percent in 1980 to 15 percent by the year 2000. Coal usage for electricity, direct use, and synthetic fuel production increases at 3.3 percent per year to reach 35 quads in 2000. Domestic oll and gas resource usage declines over time in accordance with assumptions regarding the declining resource base for 011 and gas. Declining fossil resources (avallable domestica1ly) are offset by greater use of non-fossil inputs such as geothermal and solar. The growth rate of demand for primary energy resources in the conservation case is significantly reduced from historical trends. The conservation policy enables the energy service requirements profected for the 1980 to 2000 period to be met to a greater degree with domestic resources and enables the U.S. to become independent of o1l and gas imports by the year 2000 .

Energy System Efficiencies. Table 4.22 provides several indicators of aggregate energy system efficiency for alternative measurement points In the energy system from primary energy through conversion and distribution for end use. The average supply efficiency is anticipated to decrease from .73 in 1980 to .68 by 2000 , primarily because of the trend toward increased electrification of the energy system over time. The conservation case assumes a significant level of energy savings in each consuming sector as a result of improved efficlencles in end-use conversion devices. This improvement is reflected in large increases in average demand efficiency over the projection period, from .55 in 1980 to.93 by the year 2000. Improvements in the average demand efficiency more than counterbalance the small degradation in average supply efficlency, and result in a projected increase in average system efficiency from .40 in 1980 to .62 in the year 2000 . 


\begin{tabular}{|c|c|c|c|}
\hline & $\begin{array}{l}\text { Table } 4.21 \\
\text { Primary Energy Usage: } \\
\text { Conservation Case } \\
\text { (Quadrillion Btu) }\end{array}$ & & \\
\hline & 1980 & 1990 & 2000 \\
\hline \multicolumn{4}{|l|}{ Nonrenewable } \\
\hline Oil - domestic & 21.0 & 19.3 & 16.1 \\
\hline imported & 16.2 & 5.8 & 0.0 \\
\hline shale & 0.0 & 0.3 & 0.8 \\
\hline Gas - domestic & 17.7 & 17.6 & 15.0 \\
\hline imported & 0.0 & 0.0 & 0.0 \\
\hline unconventional & 0.0 & 0.0 & 0.0 \\
\hline Coa1 & 18.2 & 28.7 & 34.8 \\
\hline Uranium & 3.4 & 6.5 & $3 \% .0$ \\
\hline Subtotal* & $\overline{76.5}$ & $\overline{78.2}$ & $\overline{73.7}$ \\
\hline \multicolumn{4}{|l|}{ Renewables } \\
\hline Wond & 1.5 & 2.6 & 2.6 \\
\hline Solid waste & 0.0 & 0.0 & 0.0 \\
\hline Biomass & 0.0 & 0.0 & 0.0 \\
\hline Hydroelectric & 3.8 & 4.6 & 5.3 \\
\hline Geothermal & 0.2 & 0.6 & 4.1 \\
\hline Solar & $* *$ & 0.6 & 1.3 \\
\hline Wind & 0.0 & 0.0 & 0.0 \\
\hline Subtotal* & 5.5 & $\overline{8.4}$ & $1 \overline{3.3}$ \\
\hline Total* & 82.0 & 86.6 & 87.1 \\
\hline Imports & 16.2 & 5.8 & 0.0 \\
\hline
\end{tabular}

* Totals may not add because of rounding. w Less than 0.05 quads.

Table 4.22

Aggregate Ēnergy Quantities and System Efficiencies: Conservation Case

\begin{tabular}{rccc}
\hline & 1980 & 1990 & 2000 \\
\hline Energy quantities (quads) & & & \\
I. Total primary energy & 82.0 & 86.6 & 87.1 \\
II Total delivered energy & 59.4 & 60.9 & 58.8 \\
III Total energy services & 32.9 & 43.4 & 54.4 \\
Aggregate efficiencies & & & \\
II/I Average supply efficiency & .73 & .70 & .68 \\
III/II Average demand efficiency & .55 & .71 & .93 \\
III/I Average system efficiency & .40 & .50 & .62 \\
\hline
\end{tabular}


4.3.4 Environmental Conditions. The energy-system-related environmental measures for the conservation policy appear in Table 4.23. These indicators all increase over time with the exception of the air emissions, which decline slightly over the 1990-2000 period and are largely dependent on the burning of fuels for electricity generation, transportation, and heat. The virtual halt in the growth of these activities as well as the shift toward more advanced (and cleaner) coal electricgenerating technologies result in the slight decrease in air emissions. These indicators imply a quantitatively cleaner and healthier environment for the conservation policy than for the reference projection.

Table 4.23

Environmental Indicators: Conservation Case

\begin{tabular}{lrrr}
\hline & 1980 & 1990 & 2000 \\
\hline Airborne emissions, $10^{6}$ tons & 31.6 & 33.3 & 32.7 \\
Waterborne emissions, $10^{6}$ tons & 1.1 & 1.6 & 1.8 \\
Person-days lost, $10^{3}$ person days & 485.8 & 607.0 & 668.6 \\
Population exposure, $10^{6}$ man-rem & 0.3 & 0.5 & 0.6 \\
\hline
\end{tabular}

5. SYNFUELS POLICY

\subsection{Introduction}

There are several possible supply strategies that could be pursued in an attempt to ease the transition away from relatively expensive imported energy sources. In this section, the projected energy, economic, and environmental implications of an enhanced synthetic fuel policy are examined using the BNL/DJA integrated model system. The specification of this synfuel policy is based upon the synthetic fuels development program proposed by President Carter on July 15, 1979. The synthetic fuels program calls for an acceleration of the synthetic fuels output levels from the projected reference case synfuels production levels over the next two decades.

\subsection{Assumptions and Méthodologies tor Synfuels Policy}

The synfuels case was modeled as a perturbation from the fully aligned reference projection. All assumptions regarding primary resource prices and availabilities, technology characteristics, and underlying economic input assumptions were identical to those for the reference case. The synfuels policy includes an accelerated schedule for availability and production of synthetic fuels, and provides for an incremental production goal of 2.5 million (crude oil equivalent) barrels per day relative to the reference case by the year 1990 . Table 5.1 presents the allocation of this incremental level of synthetic fuel production among coal liquids, high-Btu coal gas, shale oil, and unconventional and biomass gas. 
During the post-1990 period, synfuels output was assumed to increase at a slower rate of growth than in the reference case projection.

Table 5.1

Allocation of Incremental Synfuels Production for 1990:

Synfuels Case

(Millions bbl/day)

\begin{tabular}{ll}
\hline Coal liquids & 1.25 \\
Hi-Btu/coal gas & 0.25 \\
Shale oil & 0.40 \\
Biomass gas & 0.10 \\
Unconventional Gas & 0.50 \\
$\quad$ Total & $\frac{2.50}{2.50}$ \\
\hline
\end{tabular}

The assumptions regarding synthetic fuel production levels were incorporated into the BNL/DJA combined model system. The TESOM and LITM models are solved iteratively to yield the equilibrium set of energy prices and quantities, and economic activity associated with an accelerated domestic supply program.

5.3 The Synfuels Policy: Energy, Economy, and Environmental Interactions

5.3.1 Introduction. In this section, the results for the BNL/DJA synfuels analysis are discussed. The influences of an accelerated synthetic fuels policy on the growth and structure of the U.S. economy, the development of the energy system, and its environmental effects are presented.

5.3.2 Economic Strueture and Growth. Under the syntuels policy, U.S. ecinomic growth is prnjected to be maintained at a positive, lluugh declining, rate through the year 2000. The annual rate of youwth averages 2.9. percent during the $1980^{\prime}$ 's but drops to 2.5 percent over the final decade of the century. Relative to the reference projection, the rate of growth is lower and slows more rapidly with the introduction of the synfuels policy. Without special policy, new energy technolngies enter the market as they become economically competitive with the energy provided by conventional means. The synfuels policy accelerates this process of commercial deployment without regard to the relative cost positions of these technologies at their time of introduction. Forcing the higher cost technologies to be chosen over conventional supplies imposes a permanent cost, in terms of income and production foregone, that the economy must absorb.

The major labor, output, and productivity variables for the synfuels projection are summarized in Table 5.2. The rate of economic growth can be expressed as the sum of the rates of labor force expansion and gross labor productivity advance. Employment growth i.s only slightly below 
that for the reference projection, averaging 1.4 percent annually between 1980 and 1990 and approximately 1.0 percent between 1990 and 2000 . The influence of changes in the demographic structure of the population noted for the reference projection is augmented by the adverse impacts on labor force expansion from the synfuels policy. However, these employment impacts are minimal. The rate of advance in gross labor productivity bears the major portion of the macroeconomic cost of synfuels. Productivity growth is projected to be maintained at a rate of 1.5 percent per annum throughout the entire projection horizon. Thus, advances in productivity still account for an increasing fraction of economic growth, even though the rates of advance are slowed by the premature introduction of synthetic and unconventional fuels.

Table 5.2

Labor, Output, and Productivity: Synfuels Case

\begin{tabular}{|c|c|c|c|c|c|}
\hline & \multirow[b]{2}{*}{1980} & \multirow[b]{2}{*}{1990} & \multirow[b]{2}{*}{2000} & \multicolumn{2}{|c|}{$\begin{array}{l}\text { Average annual } \\
\text { rates of growth }\end{array}$} \\
\hline & & & & $\begin{array}{l}1980- \\
1990\end{array}$ & $\begin{array}{l}1990- \\
2000\end{array}$ \\
\hline Population, millions & 222.2 & 243.5 & 260.4 & 0.92 & 0.67 \\
\hline Employment, millions & 97.8 & 112.4 & 124.0 & 1.40 & 0.99 \\
\hline Real GNP, $10^{9} \$(1972)$ & 1417.1 & 1888.9 & 2413.3 & 2.92 & 2.48 \\
\hline $\begin{array}{l}\text { Real GNP per capita, } \\
10^{3} \$(1972)\end{array}$ & 6.378 & 7.757 & 9.268 & 1.98 & 1.80 \\
\hline \multicolumn{6}{|c|}{$\begin{array}{l}\text { Gross labor productivity, } \\
10^{3} \$(1972) \text { per }\end{array}$} \\
\hline worker & 14.490 & 16.805 & 19.462 & 1.49 & 1.48 \\
\hline
\end{tabular}

The volume of expenditure sustained by the economy continues to increase over time, as allowed by the rise in the level of production. The decomposition of these expenditures into consumption, investment, government, and net foreign purchases is given in Table 5.3. The 70.0 percent increase in total final purchases, from 1417.1 billion $\$(1,972)$ in 1980 to 3413.3 billion $\$(1972)$ in 2000 , is composed of increased spending by consumers, investors, and governments. Net exports alone grow smaller during this period. The largest share of total real spending is consumption, rising from 63.9 percent in 1980 to 64.8 percent in 1990 , and then falling slightly to the year 2000. Investment grows from 213.6 billion $\$(1972)$ to 359.8 billion $\$(1972)$ over this twenty-year period, but its share in the total use of output does not change significantly. On balance, the aggregate pattern of purchases changes very little under the synfuels policy. This implies that both consumption and investment bear the costs to the economy, suffering proportionately larger and smaller losses, respectively, in their growth through 2000. 


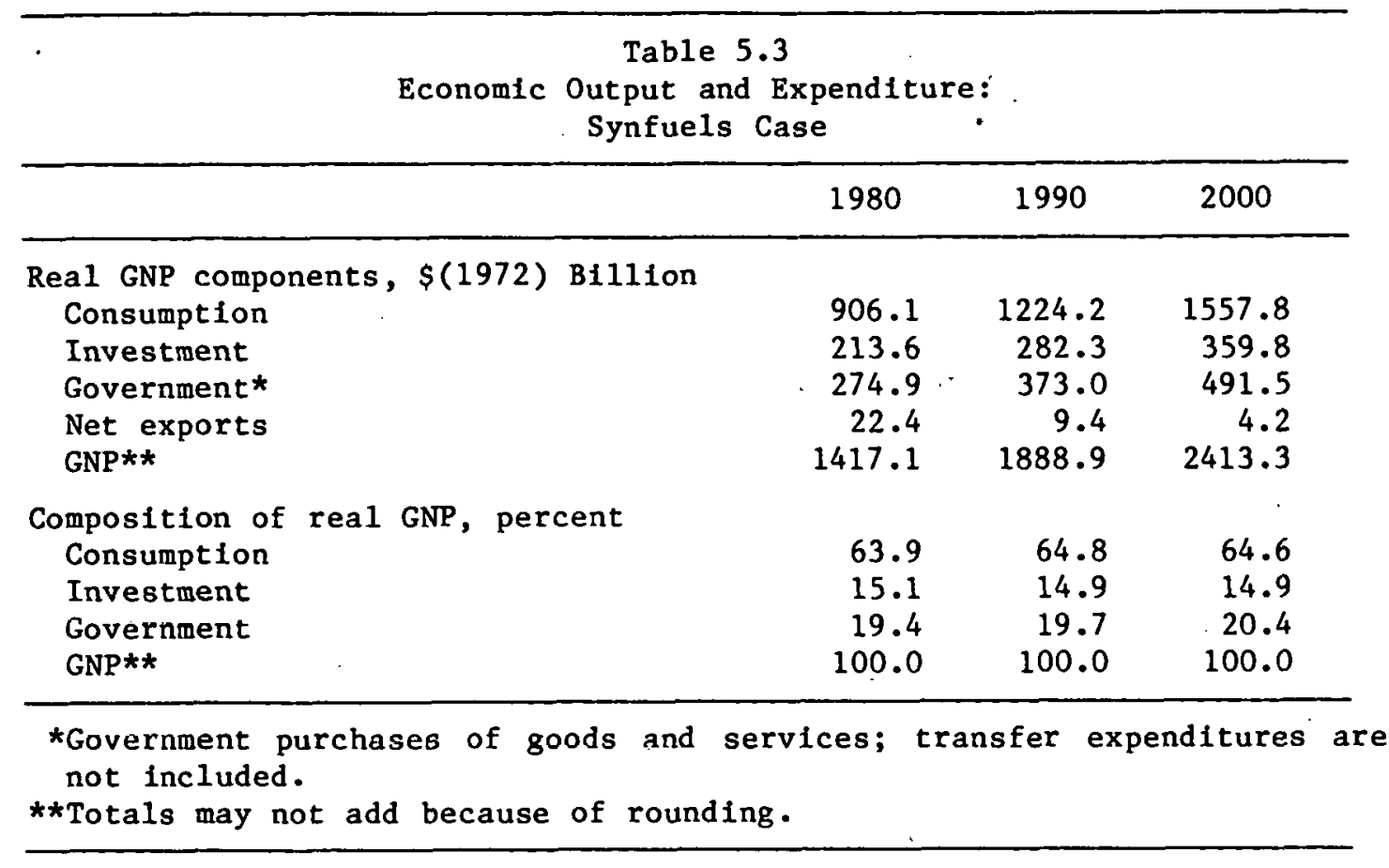

As in the reference case, the sectorial pattern of real final demand shows a substantial restructuring of the economy, in terms of the mixture of inputs from production. Table 5.4 shows the pattern of aggregate final demand expenditures with the synfuels policy in effect; these trends correspond directly to those in the reference case.

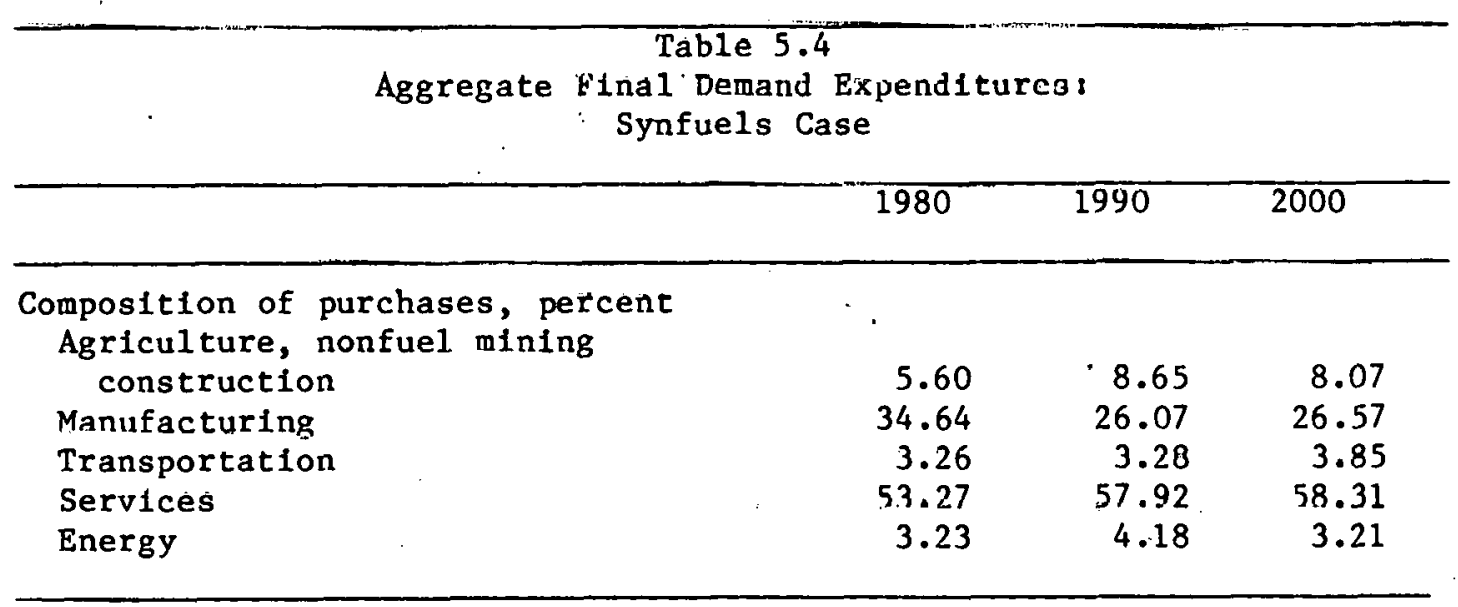


From 1980 to 1990, manufacturing declines in relative importance, with 1 ts output share falling from 35.0 to 26.0 percent. All other sectors increase their share of final demand, though for the transportation and communications sector the increase is very small. The sector with the largest rise in relative importance is trade and services, and this increasing importance continues throughout the projection horizon. This sector, therefore, contributes a major portion of the growth in economic activity and accounts for a large fraction of the associated increased spending.

The share of final demand for energy exhibits a trend similar to that of the reference case. Here, also, the Increase from 1980 to 1990 is explained by the combination of real energy price increases, relatively strong economic growth, and the relative rigidity in the turnover of energy-consuming capital stocks. But, the synfuels policy augments this rise in energy's share of total spending. The fraction spent on energy in total final demand purchases in 1990 is somewhat higher than that in the reference case. This is caused by the forced substitution of the more costly synthetic fuels for less expensive energy available from conventional sources. After 1990, demand adjustments, 1.e., substitutions away from higher priced energy, are more complete and synthetic fuels become more competitive. As a result, energy final demand purchases stabilize; by 2000, energy's share of total final spending returns to approximately the same level it held in 1980.

Under the synfuels policy there is also a significant change in the operation of the economy, in terms of how output is produced. The capital, labor, energy, and intermediate materials coefficients, representing the aggregate structure of inputs to production, are presented in Table 5.5. The major trends are once again similar to those in the reference case. But the magnitude of changes from 1980 to 1990 is affected by the introduction of synthetic and unconventional fuels. There is a consistent pattern of restructuring, as capital becomes relatively more important, and energy and labor become less so. The capltal-1abor ratio increases at an average annual rate of 2.6 percent; as described, this contributes to advances in gross labor productivity. Also, notable is the reduction in energy's share of total inputs and the average decrease in energy per unit of capital; the energy efficiency of capital improves by approximately 2.0 percent annually. However, energy's share does not decline as rapidly as in the reference case. This is another outcome of the imposed substitution of relatively higher priced energy associated with the synfuels policy. Nelther the rate of incrcaoc in capital per worker nor the rate of decline in the energy-capital ratio is as large under the synfuels policy as in the reference projection. Also, the rate of increase in the capital intensity of aggregate output is larger and the rate of decrease in labor intensity is smaller with the synfuel programs. Consequently, relative to the reference projection, the synfuels policy results in a faster decline in capital productivity and slower rates of advance for both gross and net labor productivities and the aggregate economic efficiency of energy use. 


\begin{tabular}{|c|c|c|c|}
\hline & \multicolumn{3}{|c|}{$\begin{array}{c}\text { Table } 5.5 \\
\text { Aggregate Economic Input Patterns; } \\
\text { Share Coefficients for Aggregate Output: } \\
\text { Synfuels Case }\end{array}$} \\
\hline & 1980 & 1990 & 2000 \\
\hline \multicolumn{4}{|c|}{ Input coefficient } \\
\hline Capital & .1505 & .1793 & .2052 \\
\hline Labor & .2273 & .2080 & .1845 \\
\hline Energy & .0314 & .0298 & .0283 \\
\hline Materials & .5908 & .5829 & .5819 \\
\hline
\end{tabular}

\subsubsection{Energy System Development}

Energy Service Demands. The aggregate demand for energy services in the synfuels case increases at an average annual rate of 2.8 percent during the 1980 to 1990 period, and at a slower rate of 2.1 percent during the following decade. The levels of energy service demands for each consuming sector are given in Table 5.6. Total energy service demands are projected to rise from 32.9 quads in 1980 to 43.3 quads in 1990 , and to 53.2 quads by the year 2000. Industrial energy services account for the largest share of total service demand in all years. Industrial service requirements increase at an average rate of 2.7 percent per year over the 1980 to 2000 period, while residential/commercial and transportation services increase at slower rates of 2.1 and 2.2 percent, respectively. Residential/commercial demands for space conditioning, water heating, and electricity increase from 10.7 quads in 1980 to 16.3 quads by 2000 , maintaining a relatively constant share of total energy sorvice demands throughout the period. The restructuring of energy service demands over time indicates a shift away from oil-iuleusive encrgy services, partlcularly transportation demands. The aggregate level of transportation services increases from 4.2 quads in 1980 to 6.5 quads by 2000; however, the transportation component of total energy services de$\mathrm{clines}$ from 12.8 percent in 1980 to account for 11.9 percent by the year 2000. Within the transportation sector, the pattern of transportation modes changes over time. The trend toward mass transit over the 1980 to 2000 period is reflected in the relatively slower 1.3 percent per annum growth rate for privale ground transportation, as compared to growth rates of 3.5 and 4.5 percent for electric rail and air transportation seivices.

Delivered Energy Prices and Quantities. Consumption levels for delivered energy by aggregate economic sector are given is Tahle 5.7 . Total delivered energy grows at an average annual rate of 1.2 percent from 1980 to 2000, rising from 59 quads in 1980 to 68 and 76 quads for the years 1990 and 2000, respectively. Industrial consumption of delivered fuels increases most rapidly, and grows at an average rate of. 


\begin{tabular}{|c|c|c|c|}
\hline \multicolumn{4}{|c|}{$\begin{array}{c}\text { Table } 5.6 \\
\text { Energy Service Demands: } \\
\text { Synfuels Case } \\
\text { (Quadrillion Btu) }\end{array}$} \\
\hline & 1980 & 1990 & 2000 \\
\hline $\begin{array}{l}\text { Residential/commercial } \\
\text { Space conditioning } \\
\text { Miscellaneous thermal } \\
\text { Miscellaneous electric } \\
\text { Subtotal* }\end{array}$ & $\begin{array}{r}6.6 \\
1.9 \\
2.2 \\
10.7\end{array}$ & $\begin{array}{r}10.1 \\
2.0 \\
2.5 \\
14.6\end{array}$ & $\begin{array}{r}11.2 \\
2.1 \\
3.0 \\
16.3\end{array}$ \\
\hline $\begin{array}{l}\text { Industrial } \\
\text { Process heat } \\
\text { Aluminum } \\
\text { Iron and steel } \\
\text { Miscellaneous electric } \\
\text { Petrochemicals } \\
\text { Subtotal* }\end{array}$ & $\begin{array}{r}9.6 \\
0.2 \\
0.6 \\
2.8 \\
4.8 \\
18.0\end{array}$ & $\begin{array}{r}12.1 \\
0.2 \\
0.7 \\
4.0 \\
6.4 \\
23.4\end{array}$ & $\begin{array}{r}15.0 \\
0.4 \\
1.0 \\
5.4 \\
8.7 \\
30.5\end{array}$ \\
\hline $\begin{array}{l}\text { Transportation } \\
\text { Private ground transportation } \\
\text { Truck, Bus, rail, and ship } \\
\text { Air transport } \\
\text { Electric rail } \\
\text { Subtotal* }\end{array}$ & $\begin{array}{l}2.0 \\
1.5 \\
0.7 \\
0.1 \\
4.2 \\
\end{array}$ & $\begin{array}{l}2.3 \\
1.7 \\
1.3 \\
0.1 \\
5.4 \\
\end{array}$ & $\begin{array}{l}2.6 \\
2.0 \\
1.7 \\
0.2 \\
6.5 \\
\end{array}$ \\
\hline Total energy service demand* & $\overline{32.9}$ & $\overline{43.3}$ & $\overline{53.2}$ \\
\hline
\end{tabular}

*Totals may not add because of rounding.

2.1 percent per year to account for 48 percent of total delivered energy by 2000 . During the 1980 to 1990 period, residential/commercial consumption of energy increases from 14.5 to 18.1 quads: After 1990, the substitution of gas, electricity, and direct heat for petroleum products and the turnover of the capital stock to more efficient devices enables the residential/comercial sector to satisfy an increased demand for energy services with a lower level of delivered energy in the year 2000 of 17.3 quadrillion Btu. The amount of delivered energy used to provide transportation services remains relatively stable over the 1980 to 2000 period, ranging from 20.8 to 20.4 quads. The share of total delivered energy consumed by the transportation sector declines from 35 percent in 1980 to 29 percent by 2000 . 
Table 5.7

Delivered Energy Quantities by

Aggregate Economic Sector:

Synfuels Case

(Quadrillion Btu)

\begin{tabular}{llll}
\hline & 1980 & 1990 & 2000 \\
\hline Residential/commercial & 14.5 & 18.1 & 17.3 \\
Industrial & 24.1 & 29.3 & 36.4 \\
Transportation & $\frac{20.8}{59.4}$ & $\frac{20.9}{68.3}$ & $\frac{22.4}{76.1}$ \\
Total* & & \\
\hline
\end{tabular}

*Totals may not add because of rounding.

The quantities of delivered energy by fuel type for the synfuels case are provided in Table 5.8. Consumption of solid fuel, which includes coal, coke, and wood, is projected to double from a 1980 level of 6 quads by the year 2000. Higher levels of coal combustion for industrial process heating and increased use of wood burning stoves for space heating contribute to the 3.5 percent average annual growth rate in solid fuel use. Delivered liquid fuels account for the largest share of total delivered energy in all years. The share of delivered liquids decreases significantly over time, from 53 percent in 1980 to 32 percent by the year 2000, although the quantity of delivered oil products remains essentially constant during the 1990 to 2000 period. Delivered gas usage increases from 14 to 20 quads over the 1980 to 2000 period and accounts for 26 percent of total delivered energy. The electric intensity of the energy system increases over time. Delivered electrlctity increases from 8 quads in 1980 to 14 quads by 2000, to account for 18 percent of delivered energy in the year 2000 .

Table 5.8

Delivered Energy Quantities by Fuel Type:

Synfuels Case

(Quadrillion Btu)

\begin{tabular}{|c|c|c|c|}
\hline & 1980 & 1990 & 2000 \\
\hline $\begin{array}{l}\text { Coal, coke, wood } \\
\text { Oil, metlanol } \\
\text { Cac, lo-Btu gas } \\
\text { Electric } \\
\text { Direct solar, geothermal, } \\
\text { and waste heat } \\
\text { Total* }\end{array}$ & $\begin{array}{r}6 \\
31 \\
14 \\
8\end{array}$ & $\begin{array}{l}11 \\
26 \\
18 \\
11\end{array}$ & $\begin{array}{l}12 \\
25 \\
20 \\
14 \\
\frac{5}{76}\end{array}$ \\
\hline
\end{tabular}


Delivered liquids are comprised of refined petroleum products, and synthetic coal 1iquid and coal methanol. Synthetic liquids account for an increasingly larger share of total liquid fuel consumption over time, rising from 2 percent in 1980 , to 34.5 percent of total 1iquids by the year 2000. Delivered gas products include refined natural gas products and hi- and 1o-Btu coal gas. The synthetic share of total gaseous fuels consumed increases similarly, from 1.4 percent in 1980 to 31.0 percent by 2000.

Delivered energy prices are given in Table 5.9 for each type of delivered energy consumed in terms of constant 1972 dollars per million Btu. The average delivered price of energy is computed as a quantityweighted average of the prices for all solid, 11quid, and gaseous fuels; electricity; and heat. The average price of delivered energy increases at an average annual rate of 2.2 percent from $\$ 3.68$ in 1980 to $\$ 4.57$ in the year 1990. This rapld price rise is followed by average annual increases of less than 0.2 percent during the post-1990 period.

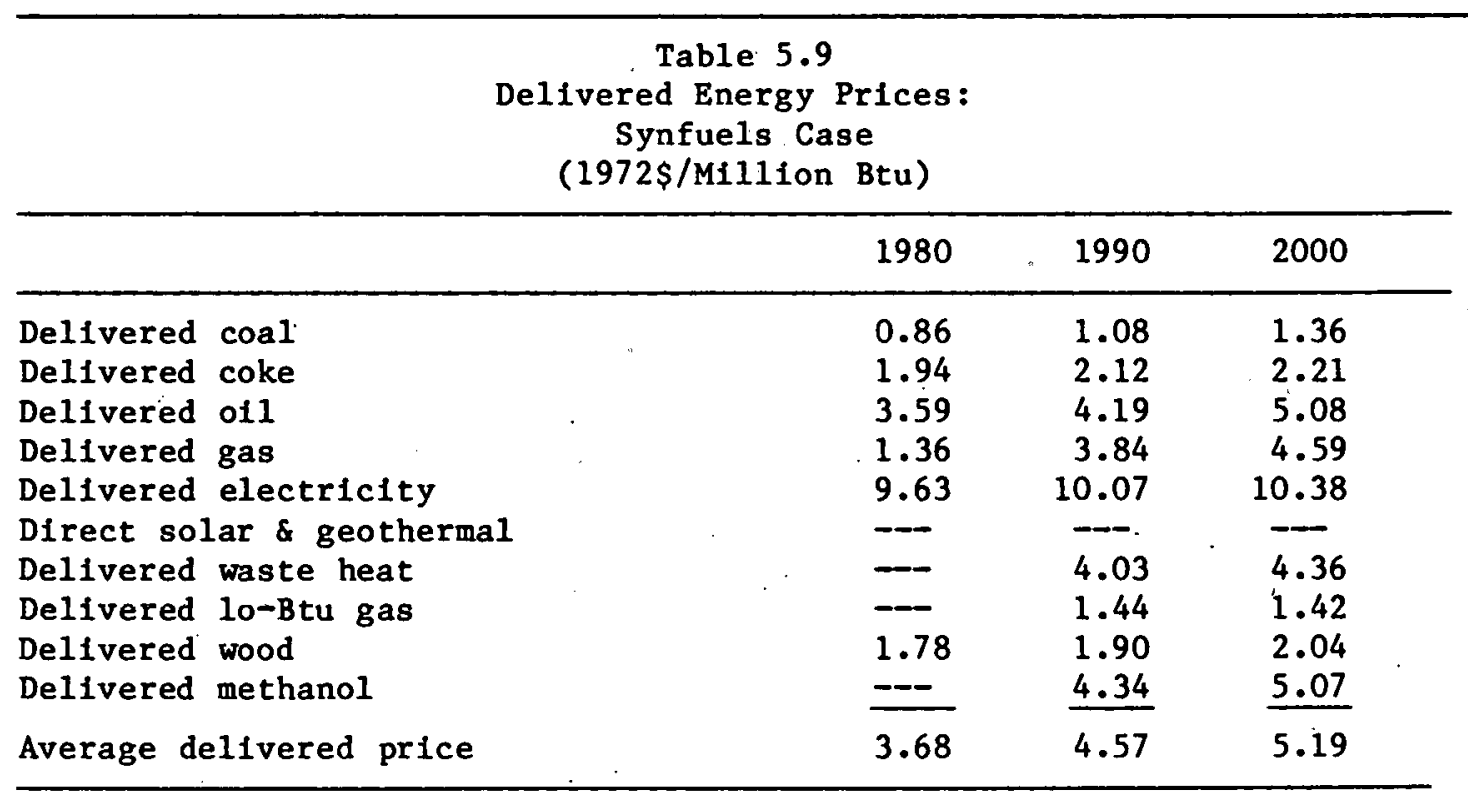

Tho price of delivered coal rises from $\$ 0.86$ in 1980 to $\$ 1.36$ by 2000 , at an average annual increase of 2.3 percent.

The average price of delivered oil products, computed as a quantitywelghted average of the prices for gasoline, kerosine, distillate, and residual fuels; increases at an average annual rate of 0.2 percent from 1980 to 2000 .

The price of delivered gas products is an average of the prices for resldential/commercial and industrial users of gas products. The dellvered gas price rises rapidly in the $1980-2000$ period as natural gas prices are deregulated, and grows from $\$ 1.36$ per million Btu in 1980 to $\$ 4.59$ by 2000 . 
Electricity prices remain relatively stable during the 1980 to 1990 period, rising from a 1980 price of $\$ 9.63$ to $\$ 10.07$ by 1990 . After 1990 , the introduction of electric district heating and industrial cogeneration plants results in the production of waste heat, in addition to generated electricity, at a cost below those for conventional plants. The electricity price rises to $\$ 10.38$ by the year 2000 .

Primary Energy Prices and Quantities. In the synfuels case total primary energy consumption is projected to rise from 82.0 quads in 1980 to 113.6 quads by the end of the century. Over the 1980-1990 period primary energy usage grows at 1.9 percent per year, but slows to an annual rate of 1.4 percent over the next ten years as the energy-using capital stock becomes increasingly responsive to advancing relative prices of energy. Primary resource consumption levels are given in Table 5.10 .

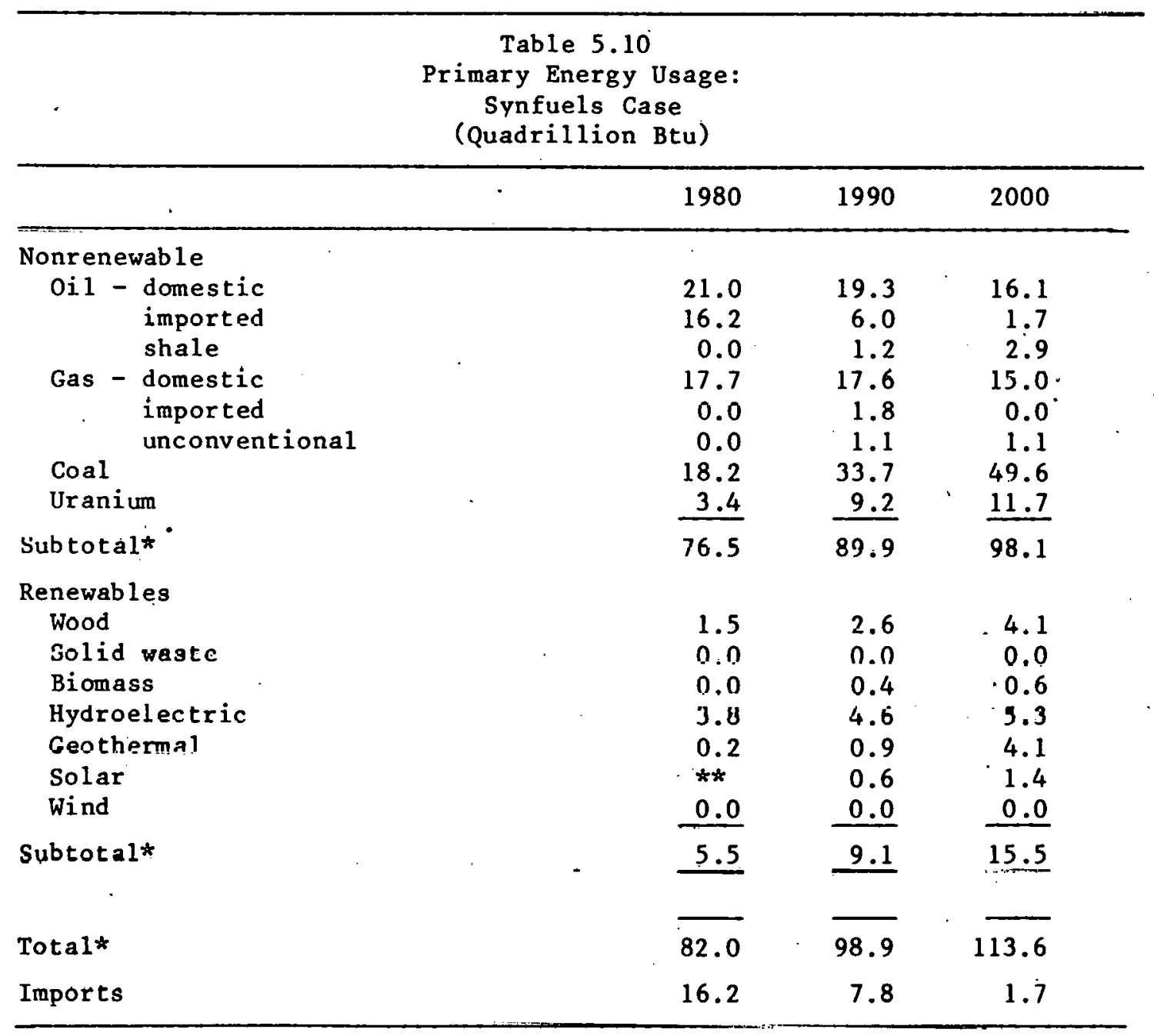

*Totals may not add because of rounding

**Less than 0.05 quads 
The average supply price of primary energy grows from $\$ 1.53$ (measured in constant 1972 dollars per million Btu) to $\$ 2.19$ in 2000 , at an average annual increase of 1.8 percent, as shown in Table 5.11 .

Table 5.11

Total Primary Energy Usage and Average Price: Synfuels Case

\begin{tabular}{lcccc}
\hline Year & $\begin{array}{c}\text { Usage } \\
\left(10^{15}{ }_{\text {Btu }}\right)\end{array}$ & $\begin{array}{c}\text { Average annual } \\
\text { growth rate } \\
\text { (percent) }\end{array}$ & $\left(1972 \$ / 10^{6}\right.$ Btu) & $\begin{array}{c}\text { Average annual } \\
\text { growth rate } \\
\text { (percent) }\end{array}$ \\
\hline 1980 & 82.0 & & 1.53 & \\
1990 & 98.9 & 1.9 & 1.95 & 2.4 \\
2000 & 113.6 & 1.4 & 2.19 & 1.1 \\
\hline
\end{tabular}

The average supply price is a quantity-weighted average of the exogenously specified prices for domestic, imported, and shale oil; domestic, imported, and unconventional gas; coal; uranium; wood; solid waste; and biomass. The growth in the average supply price is a function of both the prices of individual energy resources and the changing mix of these resources as the energy system shifts towards those resources with relatively lower prices.

The price of domestic and imported crude oil grows at an average annual rate of 3.3 percent over the 1980-2000 period, which results in a decreased dependence on oil, with its use declining at an average rate of 4.5 percent per year during the 1980-2000 period. Conventional oil's share of total resource consumption drops from 46 percent in 1980 to 18 percent in 2000.

The rapid price increases for natural gas in the 1980 to 2000 period result in a decreasing dependence on gas resources. Natural gas usage drops from 22 percent of total primary energy in 1980 to 14 percent in 2000. Synthetic gases, which become relatively less expensive than natural gas, play a larger role in energy consumption over time.

Dependence on imported oil and gas declines substantially over the projected period. Oil imports decrease to 6.0 quads by 1990 , and account for only 1.7 quads of total primary energy in the year 2000. As a synthetic liquid and gaseous fuels become available, gas imports decline to zero by 2000. Oil imports continue throughout the 1980 to 2000 period, since declines in domestic oil production are not totally offset by accelerated synthetic liquids production.

Throughout the projection period there is continued expansion of coal usage. The supply price of coal is projected to rise at a significantly lower rate than for other nonrenewable resources. The use of coal for synthetic liquid and gas production, and for electricicy production, increases to an average annual rate of 5.1 percent in the 
1980 to 2000 period. By 2000, coal provides 44 percent of total primary energy needs and replaces oil as the largest component of total energy resources.

Nuclear electricity inputs were constrained to about 12 quads in 2000. Uranium inputs account for 4 to 10 percent of total primary energy in the years 1980 and 2000 , respectively.

The aggregate level of nonrenewable energy resources declines continually. There is a rapid decrease over the 1980-2000 period, as the share of primary resources from nonrenewables falls from 93 percent in 1980 to 86 percent in 2000. A broad range of new technologies and supplies contributes to the increasing importance of renewable energy resources. The use of wood for heating and electricity generation increases to provide 4 percent of primary energy by the year 2000 . Hydroelectric power increases at essentially the same rate as total primary energy, and maintains a. 5 percent share of total energy throughout the period. Biomass, used primarily for electricity generation, provides only a small portion of total resource requirements. Direct solar heating rises to 1.4 quads in 2000, and geothermal energy for heating and electricity production increases to 4 quads in the year 2000 .

Energy System Efficiencies. Table 5.12 provides several aggregate measures of efficiency for energy conversion and utilization for the synfuels case. The average eficiency of conversion from primary resources to delivered energy, denoted the average supply efficiency, decreases from .73 in 1980 to .67 by 2000 . This decline is primarily due to substitution of electricity and synthetic fuels for imported oil. The efficiency measure from delivered energy to energy services is denoted the average demand efficiency. The demand efficiency is projected to increase from .55 to ..70 over the 1980 to 2000 period as a result of projected improvemencs in end-use devices. The average system efficiency, defined as the ratio of total energy services to total primary energy input, increases from .40 in 1980 to .47 by the year 2000 , as a result of fuel substitutiono and terhnology improvements.

Table 5.12

Aggregate Energy Quantities and

System Efficiencies:

Synfuels Case

\begin{tabular}{lrrr}
\hline & 1980 & 1990 & 2000 \\
\hline Energy. quantities (quads) & & & \\
T Total Primary energy & 82.0 & 98.9 & 113.6 \\
II Total delivered enérgy & 59.4 & 68.3 & 76.1 \\
III Total energy services & 32.9 & 43.3 & 53.2 \\
Aggregate efficiencies & & & \\
II/I Average supply efficiency & .73 & .69 & .67 \\
III/II Average demand efficiency & .55 & .63 & .70 \\
III/I Average system efficiency & .40 & .44 & .47 \\
\hline
\end{tabular}


5.3.4 Environmental Conditions: 'The energy-system-related enviromental indicators for the synfuels policy are presented in Table 5.13. As in the reference projection, these measures all increase over time as the energy extraction, conversion, and consumption activities increase: Almost all of these measures indicate an environment in the synfuels case that is relatively less clean and healthy environment than in the reference case. Population exposure to radiation, however, does not change between these projections as the level of nuclear-generated electricity remains constant between them.

Table 5.13

Environmental Indicators: Synfuels Policy

\begin{tabular}{lrrrr}
\hline & 1980 & 1990 & \multicolumn{1}{c}{2000} \\
\hline Airborne emissions, $10^{6}$ tons & & 31.6 & 38.1 & 46.6 \\
Waterborne emissions $10^{6}$ tons & 1.1 & 2.0 & 2.7 \\
Person-days lost, $10^{3}$ person-days & 485.8 & 725.5 & 1122.7 \\
Population exposure, $10^{6}$ man-rems & 0.3 & 0.7 & 0.9 \\
\hline
\end{tabular}

\section{REFERENCES}

1. Davitian, H., Groncki, P.J., Kleeman, P., Lukachinski, J., Goettle, R.J., and Hudson, E.A., A Strategic Cost-Benefit Analysis of Energy Policies: Overview, BNL 51105, 1979.

2. Davitian, H., Groncki, P.J., Kleeman, P., Lukachinski, J., Goettle, R.J., and Hudson, E.A., A Strategic Cost Benefit Analysis of Energy Policies: Comparative Analysis, BNL 51128, 1979.

3. Hudson, E.A. and Jorgenson, D.W., The Long-Term Interindustry Transactions Model: A Simulation Model for Energy and Economic Analysis, Final Report to the Applied Economics Division, Federal Preparedness Agency, General Services Administration, 1977.

4. Kydes, A.S., The Brookhaven Energy System Optimization Model: Its Variants and Uses, BNL 50873, 1978.

5. Fraser, J.T., Documentation of the Brookhaven Energy I-O and I-O/BESOM Linkage, BNL 50856, 1978.

6. Groncki, P.J. and Marcuse, W., The Brookhaven Integrated Energy/Economy Modeling System and Its Uses in Conservation and Policy Analysis, BNL $51056,1979$. 


\section{REFERENCES（CONT'D.)}

7. Lukachinski, J., Groncki, P.J., Tessmer, R.G., Goettle, R.J., and Hudson, E.A., An Integrated Methodology for Assessing Energy-Economy Interactions, BNL 26452, 1979.

8. National Energy Plan II, U.S. Department of Energy, Washington, D.C. May 1979.

9. Kincel, Kenneth L., Murphy, Frederick H., and Everett, Charles G., An Evaluation of Natural Gas Pricing Proposals, Analysis Memorandum No. AM/IA-7802, Energy Information Administration, June 14, 1978.

10. Annual Report to Congress 1978, Vol. 3, DOE/EIA-0173/3, U.S. Department of Energy, Washington, D.C.

11. Survey of Current Business, The Input-Output Structure of the U.S. Economy, 1972. Bureau of Economic Analysis, U.S. Department of Commerce, Washington, D.C., February 1979.

U.S. GOVERNMENTT PAINTING OFFICE: $614-090-\$ 13$ 